Universidad de Lima

Escuela de Posgrado

Maestría en Tributación y Política Fiscal

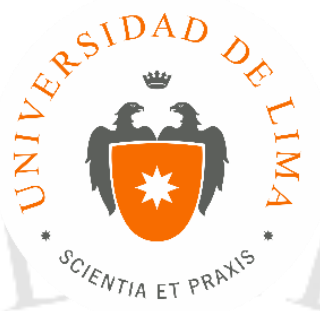

\title{
LOS ANTICIPOS DEL IMPUESTO A LA RENTA, APLICADOS EN LA ACTIVIDAD DE CASINOS Y MAQUINAS TRAGAMONEDAS
}

Trabajo de investigación para optar el Grado Académico de Maestro en Tributación y Política Fiscal

\section{Gil Jorge Cantuarias Dall'Orso}

Código 19873259

\author{
Asesor \\ Juan Pablo Porto Urrutia
}

Lima - Perú

Julio de 2017 


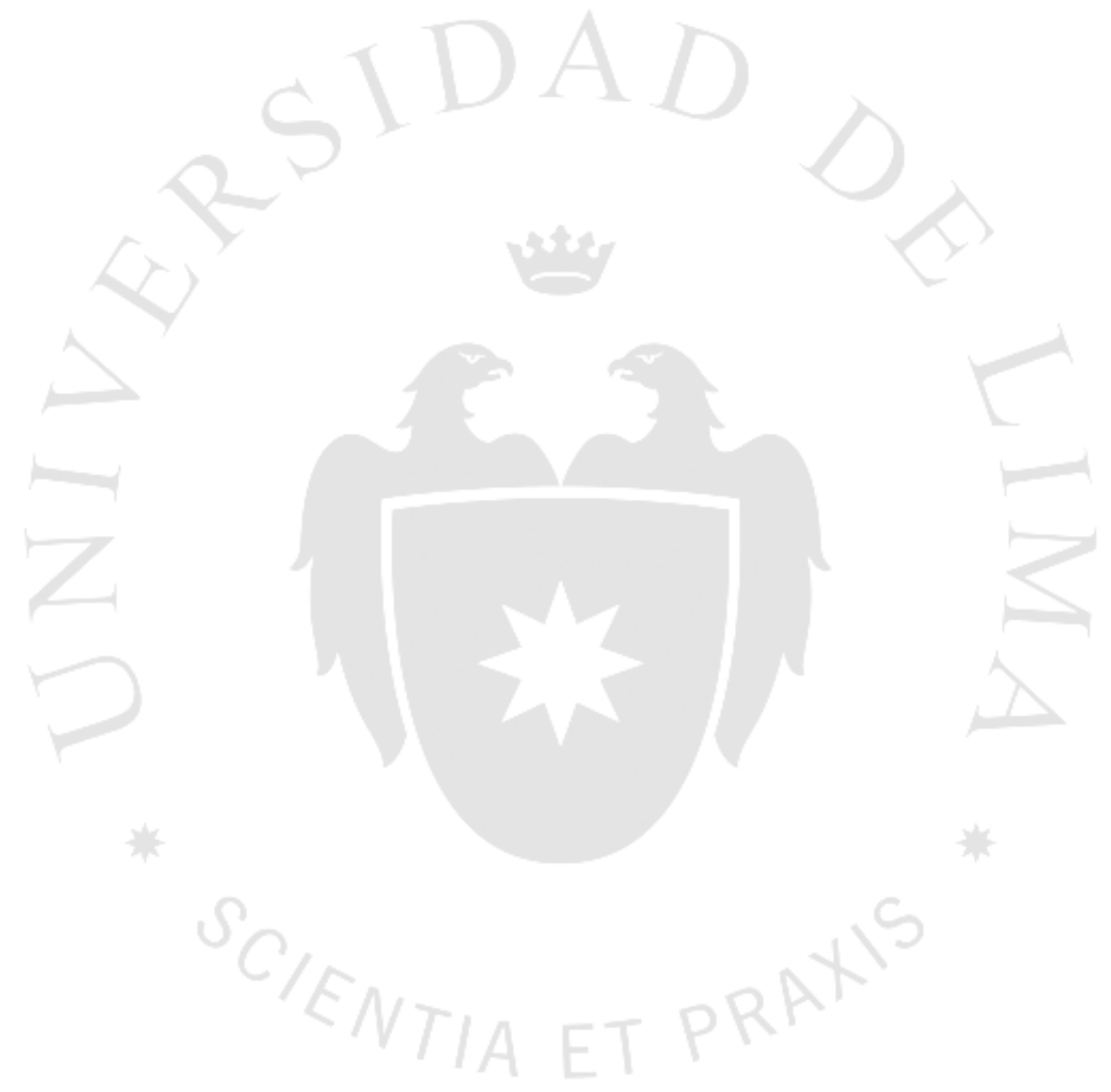




\section{LOS ANTICIPOS DEL IMPUESTO A LA}

\section{RENTA, APLICADOS EN LA ACTIVIDAD DE}

CASINOS Y MAQUINAS TRAGAMONEDAS 


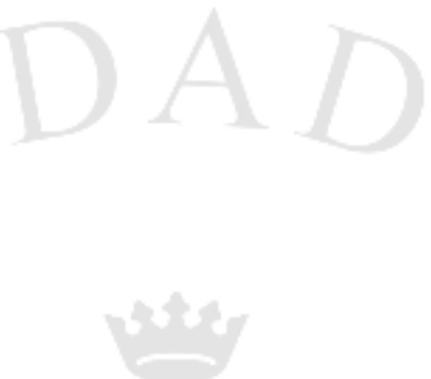

A Jorge, Mariano y Estefanía, mis amados hijos.

A Sydney, mi amada y comprensiva esposa.

A Graciela, mi adorada madre a quien le debo tanto.

Todos ellos, son la razón para mejorar cada día.

A mi padre, que se le extraña, y que siempre fue un ejemplo de dedicación, perseverancia y amor a su familia. 


\section{TABLA DE CONTENIDO}

INTRODUCCIÓN ......................................................................................................1

CAPÍTULO I: MATERIA DE LA INVESTIGACION......................................3

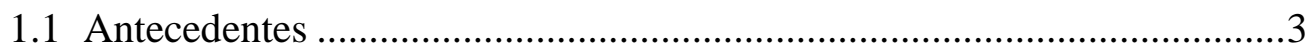

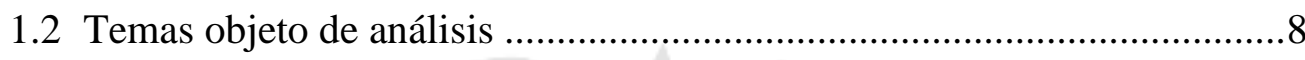

CAPÍTULO II: LEGISLACION SECTORIAL - CASINOS Y MAQUINAS

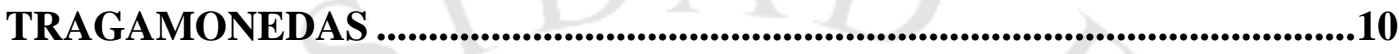

2.1. Contrato de Juego y Apuesta..................................................................10

2.2. Actividad de Casinos y Salas de Máquinas Tragamonedas .....................13

2.3. Problemática de los anticipos de la tercera categoría del IR en la actividad de casinos y salas de máquinas tragamonedas .............................................19

\section{CAPÍTULO III: ANTICIPOS DEL IMPUESTO A LA RENTA....................24}

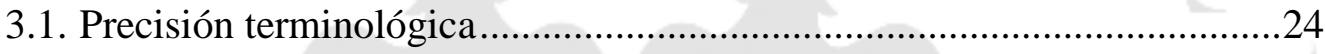

3.2. Justificación o necesidad de los anticipos ..............................................25

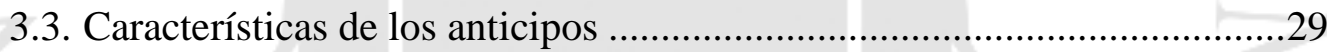

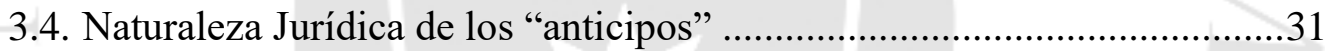

CAPÍTULO IV: CONCEPTO DE INGRESO................................................51

4.1. El término "Ingreso" en la Ley del Impuesto a la Renta.........................51

4.1.1. Interacción entre normas contables y la Ley General de Sociedades y disposiciones del Impuesto a la Renta .................................................54

4.1.2. Norma IX del Título Preliminar del CT y las normas contables .............56

4.1.3. Norma III del Título Preliminar del CT y normas contables ..................63

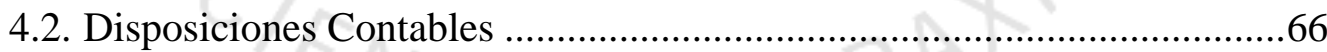

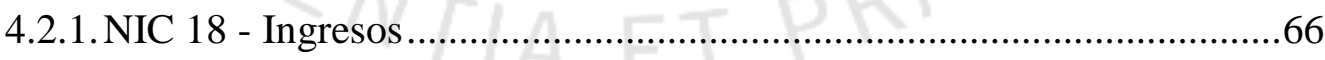

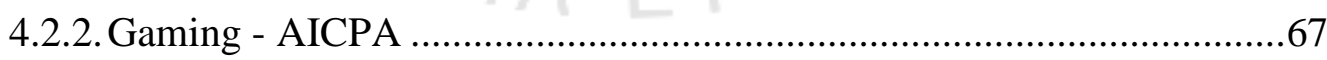

CAPÍTULO V: PRONUNCIAMIENTOS ...........................................................70

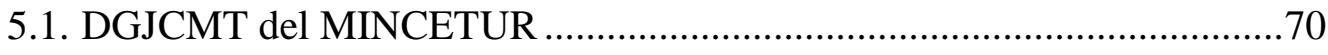

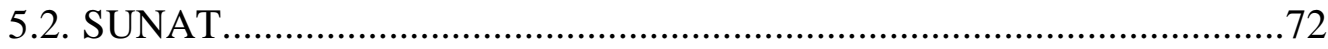

5.2.1. Informe $\mathrm{N}^{\circ}$ 211-2006-SUNAT/2B0000 ............................................72

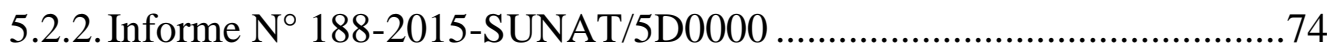

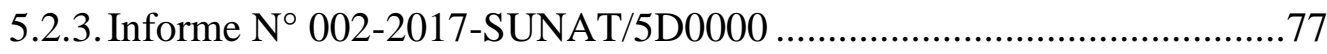




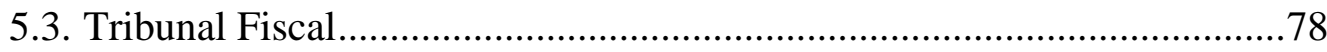

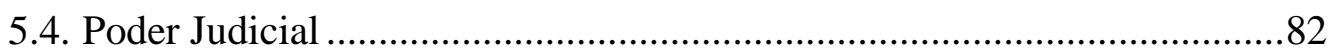

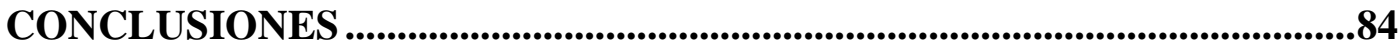

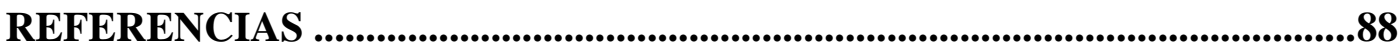

BIBLIOGRAFÍA .............................................................................................91 


\section{ABREVIATURAS}

AICPA

CySMT

CC

CCA

$\mathrm{CNC}$

CT

DGJCMT

D.Leg.

D.S.

IGV

IJ

IR

ISC

LGSNC

MC

MINCETUR

NIC

NIIF

LIR

LJ

RLIR
American Institute of Certified Public Accountants, Inc.

Casinos y Salas de Máquinas Tragamonedas

Código Civil Peruano de 1984

Código Civil Argentino

Consejo Normativo de Contabilidad

Código Tributario

Dirección General de Juegos de Casino y Máquinas

Tragamonedas

Decreto Legislativo

Decreto Supremo

Impuesto General a las Ventas

Impuesto al Juego de Casino y Máquinas Tragamonedas.

Impuesto a la Renta

Impuesto Selectivo al Consumo

Ley General del Sistema Nacional de Contabilidad

Marco Conceptual para la Preparación y Presentación de los

Estados Financieros

Ministerio de Comercio Exterior y Turismo

Normas Internacionales de Contabilidad

Normas Internacionales de Información Financiera.

Ley del Impuesto a la Renta

Ley que regula la explotación de los juegos de casino y máquinas tragamonedas

Reglamento de la Ley del Impuesto a la Renta 
RTF

SONAJA

SUNAT

TC

$\mathrm{TF}$

T.U.O.

U.S. GAAP
Resolución del Tribunal Fiscal

Sociedad Nacional de Juegos de Azar

Superintendencia Nacional de Aduanas y de Administración

Tributaria

Tribunal Constitucional

Tribunal Fiscal

Texto Único Ordenado

U.S. generally accepted accounting principles 


\section{INTRODUCCIÓN}

El tema objeto de la presente investigación se originó como producto del ejercicio profesional, entendiendo inicialmente que la problemática sólo se originaba por una mala interpretación jurídica o normativa y la falta de conocimiento de la legislación sectorial de casinos y/o salas de máquinas tragamonedas por parte de la Administración Tributaria. Sin embargo, ello resultó parcialmente cierto, ya que a mayor desarrollo del tema en las vías administrativas y judiciales, la materia objeto de estudio devela diversas cuestiones que generan controversia en el ámbito del derecho tributario.

El tema central del presente trabajo es la determinación de los anticipos de tercera categoría del Impuesto a la Renta y si para ello debe considerarse como "ingreso" la totalidad de las apuestas recibidas por el operador de casinos y/o salas de máquinas tragamonedas conforme la interpretación planteada por SUNAT en diversas fiscalizaciones y ratificada en diversos fallos del Tribunal Fiscal; o si debe considerarse como "ingreso" al diferencial resultante de restar a la totalidad de apuestas recibidas, los premios pagados a los apostadores durante el mismo período.

A priori quien inicie la lectura de este trabajo se cuestionará la relevancia práctica y teórica del presente tema. Es por ello, que en el Capítulo I se brindan las implicancias prácticas de implementar las dos (2) interpretaciones detalladas en el párrafo precedente. Considero que la materia de investigación resulta ser relevante en el plano práctico; ya que de la implementación de ambas posiciones se generan diferencias sustanciales en cuanto a los montos recaudables. Tales diferencias pueden resultar tan relevantes que de aplicarse la interpretación planteada, inicialmente, por la Administración Tributaria podría generarse el colapso de las empresas de casinos y/o salas de máquinas tragamonedas en el país.

De igual forma, en el plano teórico resulta interesante como la materia del presente trabajo, exige que se efectúe el análisis de la legislación sectorial de casinos y salas de máquinas tragamonedas, analizando las peculiaridades de la misma. Eso mismo se generó en el ámbito del derecho tributario, ya que resultó necesario analizar diversas figuras del derecho tributario, como son: (a) los "anticipos" y su naturaleza jurídica, (b) 
los principios constitucionales aplicables a los anticipos, (c) las lagunas de ley, (d) la integración analógica en el derecho tributario, (e) las fuentes del derecho tributario, (f) la difícil relación, convivencia e interacción entre las normas contables y las normas tributarias.

No deseo concluir esta breve introducción, sin reconocer la necesidad que la Administración Tributaria desarrolle sus labores de recaudación y fiscalización; sin embargo, se debe cuestionar la labor desarrollada por ésta durante las diversas etapas en las que pudo evaluar el tema de controversia, que es materia del presente trabajo. Si la Administración Tributaria hubiera actuado teniendo presente los principios constitucionales existentes en el artículo 74 de la Constitución Política de 1993 y hubiera efectuado un análisis de los efectos derivados de su interpretación planteada, podría haberse concluido que carecían de toda razonabilidad y generaban un efecto confiscatorio. Tal falta de criterio ha generado que estos temas hayan llegado a los tribunales, generando sobrecostos innecesarios al sector privado y al Estado (SUNAT, Tribunal Fiscal y Poder judicial). 


\section{CAPÍTULO I: MATERIA DE LA INVESTIGACION}

\subsection{Antecedentes}

A partir del año 2008 la Superintendencia Nacional de Aduanas y de Administración Tributaria (SUNAT) inició fiscalizaciones, contra diversas empresas operadoras de casinos y salas de máquinas tragamonedas.

Como resultado de tales fiscalizaciones, SUNAT efectuó observaciones a la determinación de los anticipos de la tercera categoría del Impuesto a la Renta. (IR)

En efecto, SUNAT observó la base de cálculo de tales anticipos, ya que consideraban que los mismos debían ser determinados tomando como base el total de las apuestas efectuadas por los clientes en cada uno de los locales, durante el período mensual. SUNAT sustentó la observación formulada en base al Informe No 211-2006SUNAT/2B0000.

Durante los procedimientos de fiscalización, los contribuyentes sostuvieron que los anticipos de tercera categoría del IR, debían ser determinados tomando como base de cálculo el diferencial resultante de restar al total de apuestas efectuadas por los clientes en los locales de casinos y/o salas de máquinas tragamonedas, los premios pagados a los clientes en el mismo período.

En los resultados de los requerimientos SUNAT mantuvo los reparos a la determinación de los anticipos categoría del IR; por lo cual, procedió a emitir y notificar resoluciones de determinación y de multa a diversos operadores de casinos y/o salas de máquinas tragamonedas. Tales resoluciones de determinación y de multa fueron objeto de reclamación ante SUNAT, iniciando así procedimientos administrativos, que particularmente en tres (3) casos ya han concluido con resoluciones del Tribunal Fiscal, adversas a los intereses de los contribuyentes y que actualmente se vienen discutiendo en la vía judicial.

Por otro lado, si bien en las resoluciones de determinación inicialmente acotadas sólo se viene solicitando el pago de los intereses, ya que a tal fecha el IR ya se había declarado y pagado, las resoluciones de multa, emitidas al amparo del numeral 1 del artículo 178 del Código Tributario (CT), si resultaban ser cuantiosas. 
Adicionalmente, estos casos resultan relevantes por que de mantenerse la posición formulada por SUNAT, se debería variar la forma de determinación de tales anticipos; generándose obligaciones de pago mensuales que largamente excederían el IR que les correspondería pagar.

Como es conocido en el medio local, los anticipos de la tercera categoría del IR se determinan sobre la base de los ingresos netos devengados en cada período mensual, conforme a lo establecido por el artículo 85 de la Ley del Impuesto a la Renta (LIR).

De igual forma, el artículo 85 de la LIR como el numeral 3 del artículo 54 del Reglamento de la LIR (RLIR), definen por "ingreso neto" al "total de ingresos gravables de tercera categoría devengados en cada mes, menos las devoluciones, bonificaciones, descuentos y demás conceptos de naturaleza similar que respondan a la costumbre de la plaza."

Sin embargo, la normativa del IR no contiene una definición de lo que debe entenderse por "ingreso"; generándose un vacío normativo, relevante para efectos del IR.

Hasta aquí, surgen las siguientes preguntas: (i) ¿cuál es la relevancia de este tema?, (ii) ¿En que afecta la discrepancia de interpretación existente entre SUNAT y los contribuyentes?, si total los anticipos de tercera categoría del IR son aplicados contra el IR que se genera al final del ejercicio.

Para dar respuesta a esas dos interrogantes, es conveniente efectuar un ejercicio numérico en el que se plasmen ambas interpretaciones. A continuación, se brinda el ejercicio numérico en el que se han empleado cifras verdaderas de un operador de salas de máquinas tragamonedas del país, que corresponden al ejercicio $2016 .{ }^{1}$

La empresa operadora de salas de máquinas tragamonedas obtuvo las siguientes cifras durante el ejercicio gravable 2016:
(a) Coin In mensual (apuestas)
S/. 249’166,666.67
(b) Net Win mensual
S/. 11’212,500.98
(c) Retorno de apuestas
$95.5 \%{ }^{2}$

\footnotetext{
${ }^{1}$ No se brinda el nombre del operador de salas de máquinas tragamonedas; sin embargo, fui autorizado para el empleo de las cifras que se han consignado.

${ }^{2}$ Del artículo 10 de la Ley $N^{\circ} 27153$, se exige que el retorno de las apuestas al público no puede ser menor del $85 \%$. Este tema será desarrollado en el Capítulo II del presente trabajo, cuando tratemos la legislación sectorial.
} 
(d) Utilidad contable 2016

S/. 31'524,582.00

(e) Utilidad tributaria 2016

S/. $40^{\prime} 037,880.00$

(f) IR $(28 \%)$

S/. 11’210,606.00

(g) Anticipos de 2016

S/. 9418,500.00

(h) Coeficiente empleado

0.07

Tabla 1.1.

Determinación de anticipos, interpretación SUNAT

\begin{tabular}{|c|c|c|}
\hline Coin In Mensual & Coeficiente & Anticipo Mensual \\
\hline S/.249,166,666.67 & $\begin{array}{r}0.07 \\
-\quad \\
\end{array}$ & S/.17,441,666.67 \\
\hline Coin In Anual & Coeficiente & Total de Anticipos del Año \\
\hline $\mathrm{S} / .2,990,000,000.00$ & 0.07 & S/.209,300,000.00 \\
\hline
\end{tabular}

\begin{tabular}{|c|c|c|}
\hline Coin In a Julio & Coeficiente & Total de Anticipos a Julio \\
\hline S/.1,744,166,666.69 & 0.07 & S/.122,091,666.66 \\
\hline
\end{tabular}

Tabla 1.2

Determinación de anticipos, interpretación Contribuyente

\begin{tabular}{|c|c|c|}
\hline Net Win Mensual & Coeficiente & Anticipo Mensual \\
\hline S/.11,212,500.98 & 0.07 & \\
\hline & & Total de Anticipos Anual \\
\hline Net Win Anual & Coeficiente & S/.9,418,500 \\
\hline S/.148,325,291.76 & 0.07 & \\
\hline
\end{tabular}

Del ejercicio numérico presentado, se evidencia que:

\footnotetext{
${ }^{3}$ Se considera el anticipo hasta julio, ya que los contribuyentes que determinan los anticipos de tercera categoría del IR en función al literal a) del artículo 85 de la LIR, pueden suspender los anticipos a partir de agosto de cada año, al amparo de lo dispuesto por el numeral iii del artículo 85 de la LIR.
} 
(a) De emplearse la interpretación planteada por el contribuyente, el total de montos pagados por concepto de anticipos de tercera categoría del ejercicio 2016 ascendió a S/. 9`418,500.00 y el IR de ese mismo período ascendió a S/. 11²10,616.00.

(b) De emplearse la interpretación planteada por SUNAT, el monto que debió pagarse en un solo mes del ejercicio 2016, por concepto de anticipos hubiera ascendido a S/. 17,441,666.67, monto que superaría la totalidad del IR anual del 2016, en S/ 6’231,050.67.

(c) De emplearse la interpretación planteada por SUNAT, los montos pagados por concepto de anticipos de tercera categoría del ejercicio 2016 habrían ascendido a S/. 209`300,000.00; mientras que el IR de ese mismo ejercicio ascendió a S/. 11²10,616.00. Resulta evidente que existe una desproporción entre los anticipos y el IR, careciendo de razonabilidad y atentando contra el patrimonio del contribuyente, es decir, con claras evidencia de confiscatoriedad.

(d) Lo detallado en el literal (c) precedente, se ratifica con el hecho que con la interpretación planteada por SUNAT, se obligaría al operador de salas de máquinas tragamonedas objeto del ejercicio numérico, a pagar en un año un monto equivalente al IR que debería pagar en los próximos dieciocho (18) años, aproximadamente. ${ }^{4}$

(e) Ante los excesos detallados en el literal (c) precedente, la empresa operadora de salas de máquinas tragamonedas al determinar los anticipos de la tercera categoría del IR en función al coeficiente, habría podido suspender sus anticipos a partir de agosto de 2016. Ello implica que el contribuyente habría tenido que desembolsar S/.122`091,666.66 por concepto de anticipo, monto equivalente al IR que tendría que pagar por los próximos diez (10) años, aproximadamente. ${ }^{5}$

(f) Los anticipos constituyen estimaciones razonables que, en condiciones normales, al final del ejercicio deben ser cercanas al monto del IR anual. Por ello, García Mullin (1978) detalla que:

(...) los anticipos a lo largo de un año equivaldrán al impuesto generado el año anterior. Como esa cifra se puede obtener en los primeros meses, a lo largo del año puede irse logrando una anticipación razonable, suponiendo -y esa es la principal

\footnotetext{
${ }^{4}$ Siempre que los valores se mantengan constantes en los siguientes dieciocho (18) años.

${ }^{5}$ Siempre que los valores se mantengan constantes en los siguientes diez (10) años.
} 
debilidad del sistema- que la actividad económica generadora de renta del contribuyente es aproximadamente igual en ambos años (...) (p. 173).

Atendiendo a ello, en los anticipos existen estimaciones que se elaboran en función al IR del ejercicio anterior y que reflejan la capacidad contributiva. Fernández Cartagena (1989) sostiene que en "cuanto no exista capacidad contributiva que convalide el título jurídico del Estado para exigir los pagos a cuenta, estas obligaciones perderán virtualidad jurídica por carecer de causa y, por tanto, no podrán seguir siendo exigibles por el Estado.” (p. 119)

De emplearse la interpretación planteada por SUNAT, se evidencia que los anticipos prescindirían de la capacidad contributiva del contribuyente (operador de salas de máquinas tragamonedas), pudiendo ser calificados como obligaciones tributarias confiscatorias.

(g) De aplicarse la interpretación planteada por SUNAT, generaría que el sector de juego de azar resulte inviable y quiebre; afectando directamente la recaudación tributaria del Estado.

El ejemplo numérico antes expuesto, me permite responder las dos interrogantes planteadas en párrafos precedentes y que son:

(i) ¿cuál es la relevancia de este tema? El tema del presente trabajo cuenta con relevancia a nivel teórico, ya que nos lleva a discutir y replantear diversas figuras e instituciones jurídico tributarias; sin embargo, este tema tiene, principalmente, un aspecto práctico que puede afectar el correcto desempeño de una actividad económica relevante en el país.

(ii) ¿En que afecta la discrepancia de interpretación existente entre SUNAT y los contribuyentes? Si bien de una primera impresión se puede pensar que el tema tratado no resulta relevante, ya que los anticipos de tercera categoría son aplicados contra el IR anual y de existir desembolsos en exceso procede la devolución de los mismos; sin duda, la interpretación planteada por SUNAT, generaría una distorsión de tal magnitud que podría significar el colapso de la actividad de juego de azar en el país. 
Por ello, más allá del análisis jurídico tributario, la razón y el criterio nos dicen que algo no anda bien. Por eso, reitero que el ejemplo numérico es gráfico y refleja que el tema planteado no sólo tiene una importancia a nivel teórico, sino práctico; ya que de implementarse, es probable, que se condenaría al colapso del sector juego de azar y se afectaría, significativamente, la recaudación nacional.

\subsection{Temas objeto de análisis}

En la elaboración del presente trabajo, se procederá a desarrollar y analizar las siguientes materias:

En primer término, es describirá y analizará la legislación sectorial referida a casinos y salas de máquinas tragamonedas y las peculiaridades que se derivan de ésta (Capítulo II).

De igual forma, se desarrolla la naturaleza jurídica de los anticipos de tercera categoría del IR; con la finalidad de determinar si constituyen o no obligaciones tributarias. Esto resulta ser relevante, ya que de calificar como obligaciones tributarias, le serán de aplicación los principios constitucionales que rigen el ejercicio de la potestad tributaria (Capítulo III).

Al desarrollar los principios constitucionales que rigen el ejercicio de la potestad tributaria, se buscará emplearlos como elementos de sustento para demostrar cual de las interpretaciones (SUNAT o contribuyente) debe imperar en la determinación de los anticipos de tercera categoría del IR.

Sin perjuicio de lo detallado en el párrafo precedente, en el tercer capítulo del presente trabajo, se efectuará un análisis de las normas contables que regulan la figura del "ingreso" y se analizará si las normas contables sobre la materia pueden ser empleadas para sustentar el hecho que en la actividad de casinos y salas de máquinas tragamonedas el ingreso se encuentra configurado por el resultado de restar a la totalidad de las apuestas del mes, los premios generados a los contribuyentes en el mismo período.

Como parte del análisis de las normas contables y su posible aplicación al caso, se analizará la figura de la integración analógica contemplada en la Norma IX del Título Preliminar del CT y el tema de las fuentes del derecho tributario contenidas en la Norma III del Título Preliminar del CT. 
Para mayor ilustración, en el capítulo quinto se brinda el detalle de los pronunciamientos sobre la materia, efectuados por el MINCETUR, la SUNAT y el Tribunal Fiscal. En este capítulo no sólo se detalla lo manifestado por los entes antes indicado, sino que analizaremos si lo expuesto en cada uno de los pronunciamientos, a nuestro entender, es correcto o no.

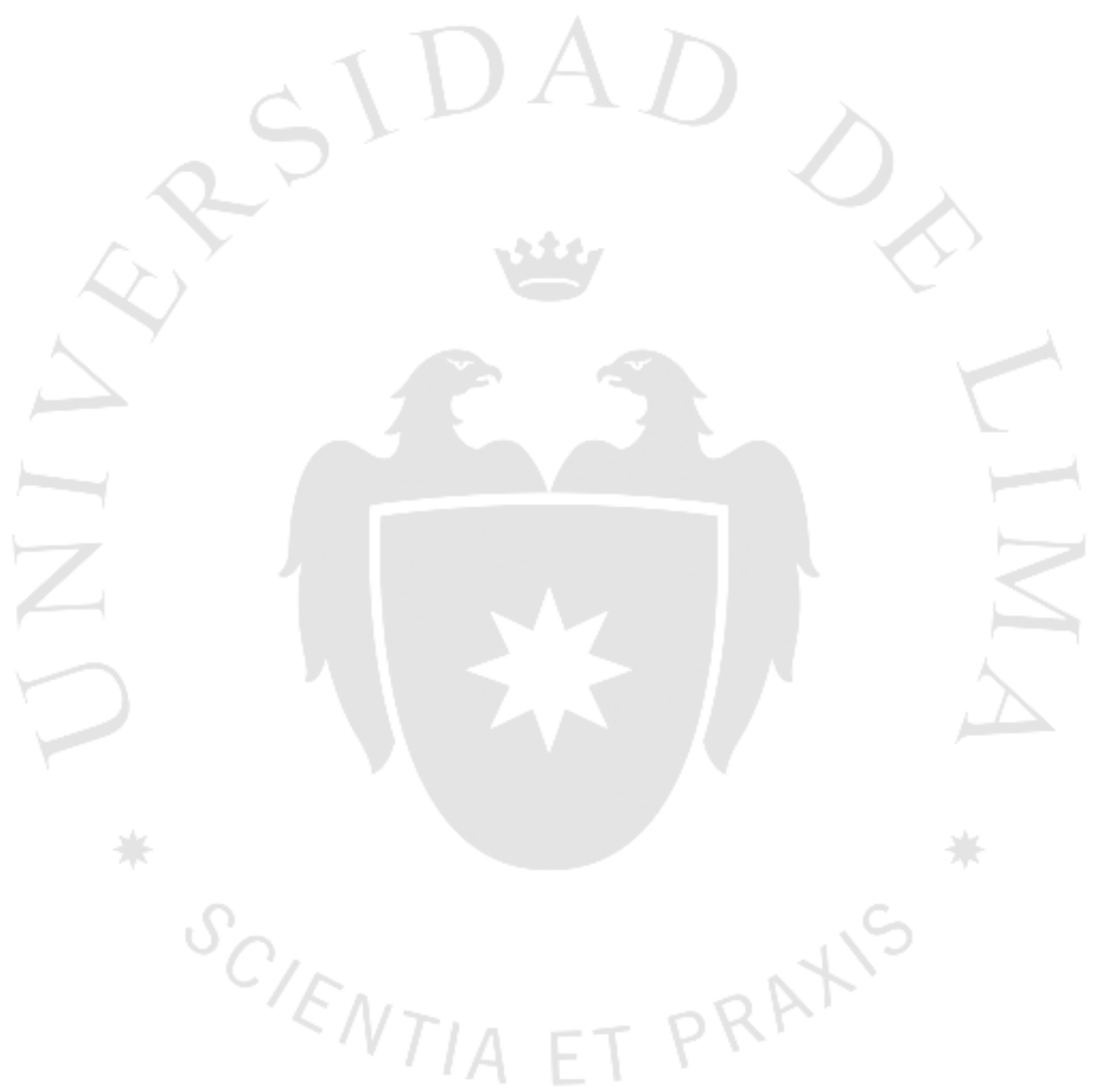




\section{CAPÍTULO II: LEGISLACION SECTORIAL - CASINOS Y MAQUINAS TRAGAMONEDAS}

\subsection{Contrato de Juego y Apuesta}

La doctrina civil clasifica a los contratos onerosos en contratos "conmutativos" y "aleatorios".

En primer caso los contratos conmutativos se caracterizan por que "los provechos y gravámenes son ciertos y conocidos desde la celebración del contrato; es decir, cuando la cuantía de las prestaciones puede determinarse desde la celebración del contrato." (Rojina Villegas, 1979, p. 13)

Por el contrario, los contratos aleatorios son aquellos donde "los provechos y gravámenes dependen de una condición o término, de tal manera que no pueda determinarse la cuantía de las prestaciones en forma exacta, sino hasta que se realice la condición o el término.” (Rojina Villegas, 1979, p. 13)

De La Puente y Lavalle (1991) establece que existen tres posiciones bajo las cuales puede entenderse a los contratos aleatorios. Una primera

El contrato aleatorio es aquél en el cual la ventaja que las partes obtendrán del contrato no es aplicable en el momento de la perfección del mismo, posición sostenida, entre otros, por MAZEAUD, entiende que la nota característica de los contratos aleatorios está dada por la existencia de un azar (chance)" (p. 219)

Una segunda posición, en la cual De la Puente y Lavalle (1991) cita a Mazeaud manifestando que en los contratos aleatorios "la nota característica y diferenciadora del contrato aleatorio es la incidencia que el evento incierto tenga sobre la existencia o sobre la determinación de una prestación.”(p. 219)

De La Puente y Lavalle (1991) sostiene que:

ALBADALEJO, por su parte, se coloca en una tercera posición, de acuerdo con la cual el contrato es aleatorio cuando las partes, al celebrarlo, asumen el riesgo de pérdida o de ganancia, bien sea mediante el establecimiento de una prestación no determinada 
concretamente o bien mediante el establecimiento de una prestación que se realizará o no eventualmente, según decida el azar (la suerte) (p. 219-220)

Conjugando estos conceptos, el contrato aleatorio puede ser definido (siguiendo siempre el criterio de la prestación) como aquél en el que la existencia o la determinación del valor concreto de la prestación o contraprestación depende de un factor incierto al momento de celebrarse el contrato, que puede alterar su contenido patrimonial. Este factor incierto es el riesgo o "alea" que ROGEL, citando a BENAVENT, dice que equivale a buena o mala suerte, equivale a azar. (p. 220)

El contrato de juego y apuesta es una especie de contrato aleatorio, en la que:

Cada una de las partes promete a la otra una prestación si las circunstancias aleatorias que intervienen no le son favorables. Las prestaciones que las partes se prometen recíprocamente, dependen del cumplimiento de condiciones opuestas e incompatibles, en el sentido que la eliminación de la incertidumbre acerca de cuál de las dos prevalecerá, ha de dejar a una sola de las partes como deudora de la otra. (Borda, 1983, p. 662)

En definitiva, el alea constituye la esencia y la base de los contratos de juego y apuesta. Ese alea se caracteriza por haber sido creado artificialmente por los aportantes. Las partes crean ese riesgo consistente en que, al tiempo de la celebración del contrato, es incierto quién ganará o perderá, e incluso, en algunos casos, que sacrificio patrimonial implicará. Ellas no tendrían ningún interés en la verificación del acontecimiento incierto si no fuera por el hecho de haber celebrado una apuesta en relación al mismo. Esto es lo que diferencia el juego y la apuesta del resto de contratos aleatorios (ej.: el seguro). (Lopez Maza, 2011, p. 144)

En los contratos de juego y apuesta se busca que el azar sea el estímulo que lleva a las partes a celebrar el contrato. Por el contrario, en los demás contratos aleatorios lo que las partes desean es eliminar o reducir el azar o riesgo, como se evidencia en el contrato de seguro.

De acuerdo con Santos Briz (1973) el contrato de juego y apuesta "se trata de la explotación del azar, entrando en ellos el factor de inseguridad como estímulo a la celebración del contrato y determinante de la ganancia o de la pérdida.” (p. 628)

De igual forma, Santos Briz (1973) entiende que en el contrato de juego y apuesta existen dos (2) contratos distintos que son regulados en conjunto. Se define por "Apuesta" “como el fortalecimiento de una afirmación mediante la promesa de una prestación para el caso de que la afirmación resulte falsa.” (p. 629) 
En cambio, por el contrato de juego se debe entender que "cada una de las partes busca la satisfacción en base a la cual se inclinó o decidió a jugar para obtener o realizar la finalidad de entretenimiento o distracción o ganancia.” (Santos Briz, 1973, p. 629)

El CC regula el contrato de Juego y Apuesta en los artículos 1942 al 1949. Tal cuerpo normativo no brinda una definición de lo que debe entenderse por juego y apuesta y sólo se limita a clasificar las modalidades del juego y apuesta que pueden existir, es decir:

(a) permitidos ${ }^{6}$;

(b) no autorizados ${ }^{7} ; \mathrm{y}$,

(c) prohibidos $^{8}$.

La clasificación de las modalidades de contratos de juego y apuesta contemplados en el CC, no implica que las modalidades detalladas en los literales (b) y (c) constituyan contratos de juego y apuesta ilícitos o que vulneran el ordenamiento jurídico.

A este respecto, los comentarios efectuados por Borda (1983) al contrato de juego y apuesta en el Código Civil Argentino, resultan de aplicación a las disposiciones del CC:

El Código distingue entre las apuestas (o juegos) que brindan acción civil al vencedor para lograr su pago y apuestas que no brindan tal acción. Estas últimas no están prohibidas por la ley; lo que el Código prohíbe es acoger la demanda por cobro de la apuesta (art. 2055); pero si la deuda se ha pagado espontáneamente, el pago es válido y el pagador no puede accionar por repetición... (p. 664).

6 Contenido en el artículo 1942 del CC, según el cual "Por el juego y la apuesta permitidos, el perdedor queda obligado a satisfacer la prestación convenida, como resultado de un acontecimiento futuro o de uno realizado, pero desconocido para las partes.

El juez puede reducir equitativamente el monto de la prestación cuando resulta excesiva en relación con la situación económica del perdedor."

7 Contenido en el artículo 1943 del CC, según el cual "El juego y la apuesta no autorizados son aquellos que tienen carácter lucrativo, sin estar prohibidos por la ley, y no otorgan acción para reclamar por su resultado.

El que paga voluntariamente una deuda emanada del juego y la apuesta no autorizados, no puede solicitar su repetición, salvo que haya mediado dolo en la obtención de la ganancia o que el repitente sea incapaz."

$8 \quad$ El texto del artículo 1944 del CC, es el siguiente: "El juego y la apuesta prohibidos son los expresamente indicados en la ley. No existe acción para reclamar por su resultado y, en caso de producirse el pago, es nulo de pleno derecho.

Nulidad de legalización de deudas de juego y apuestas." 
"En otras palabras, la ley no declara ilícito el contrato; sigue una política distinta: se abstiene de intervenir en las relaciones entre los jugadores; guarda una actitud de indiferencia." (Borda, 1983, p. 664)

Por otro lado, el artículo 1947 del CC establece que las modalidades de juegos y apuesta como loterías, pronósticos sobre competencias deportivas, apuestas hípicas, peleas de gallos y otros espectáculos y concursos similares, se deben regir por las normas legales o administrativas pertinentes. Ello implica que la regulación de tales modalidades de juego y apuesta ha sido delegada a las normas legales o administrativas que se dicten.

De lo antes indicado, se desprende que el CC no cuenta con una definición de lo que debe entenderse por juego y apuesta; sin embargo, es curioso que en el ordenamiento legal peruano las normas de carácter tributario sean las que se incorporen definiciones respecto del juego y apuesta. Entendemos que ello ocurre por la necesidad de determinar con plena certeza la hipótesis de incidencia y cumplir con el principio de reserva de ley.

En efecto, la Ley del Impuesto General a las Ventas e Impuesto Selectivo al Consumo (T.U.O. aprobado por el D.S. N ${ }^{\circ}$ 055-99-EF) estableció que se encuentran afectos al ISC los "juegos de azar y apuestas, tales como loterías, bingos, rifas, sorteos y eventos hípicos."

El artículo 16 del Reglamento del ISC a los juegos de azar y apuestas, aprobado por el D.S. N ${ }^{\circ}$ 95-96-EF, contiene las siguientes definiciones:

Juegos de Azar: "contrato aleatorio que depende absolutamente de la suerte y no de la habilidad y destreza del jugador, como las loterías, los bingos, las rifas, los sorteos, las máquinas tragamonedas y otros aspectos electrónicos.”

- $\quad$ Apuestas: "contrato que depende del azar o conjuntamente del azar y la destreza, mediante el cual se predice cierta ocurrencia o se elige ciertas combinaciones, las cuales de ser acertadas determinan la entrega de una suma de dinero o especie o la satisfacción de la prestación convenida por parte del o los que no acertaron con dicha ocurrencia, siempre que medie un organizador.”

\subsection{Actividad de Casinos y Salas de Máquinas Tragamonedas}

La actividad de casinos y salas de máquinas tragamonedas se encuentra regulada en Perú por la "Ley que regula la explotación de los juegos de casino y máquinas tragamonedas" 
(LJ) aprobada por la Ley $\mathrm{N}^{\circ} 27153$, publicada el 09 de julio de 1999; la misma que ha sido modificada por las Leyes No 27796, 28945, 29149, 29829 y 29907.

De igual forma, la LJ se encuentra reglamentada por el D.S. $\mathrm{N}^{\circ}$ 009-2002MINCETUR, el cual fue modificado por los D.S. N No 006-2008-MINCETUR, 017-2009MINCETUR, 002-2010-MINCETUR, 020-2010-MINCETUR.

Del artículo 2 de la LJ se desprende que la actividad de casinos y salas de máquinas tragamonedas "se permite de manera excepcional como parte de la actividad turística". De tal concepto se desprende que la actividad de casinos y salas de máquinas tragamonedas es aceptada y permitida; pero no fomentada por el Estado y la única justificación para permitir su desarrollo fue el considerarla como un posible motor de la actividad turística.

Habiendo transcurrido dieciocho años desde la aprobación de la LJ, resulta claro que tal actividad económica, no constituye un motor de captación de turismo, ya que la clientela que consume tal actividad es mayoritariamente de carácter local.

El artículo 4 de la LJ brinda las siguientes definiciones:

a. Juegos de Casino.- Todo juego de mesa en el que se utilice naipes, dados o ruletas y que admita apuestas del público, cuyo resultado dependa del azar, así como otros juegos a los que se les otorgue esta calificación de conformidad con la presente Ley.

b. Máquinas Tragamonedas.- Todas las máquinas de juego, electrónicas o electromecánicas, cualquiera sea su denominación, que permitan al jugador un tiempo de uso a cambio del pago del precio de la jugada en función del azar y, eventualmente, la obtención de un premio de acuerdo con el programa de juego.

Para desarrollar la actividad de explotación comercial de casinos y/o salas de máquinas tragamonedas, resulta necesario contar con una autorización expresa, otorgada por la DGJCMT del MINCETUR, conforme lo establecido en el artículo 13 de la LJ.

De igual forma, el artículo 6 de la LJ establece que sólo pueden instalarse y operar casinos y/o salas de máquinas tragamonedas en los siguientes lugares:

a) Para las Provincias de Lima y Callao, en hoteles 4 (cuatro) y 5 (cinco) estrellas o resorts equivalentes a la categoría de hotel de 5 estrellas y restaurantes turísticos 5 (cinco) tenedores.

b) Para las demás provincias y distritos del interior del país, en hoteles 3 (tres), 4 (cuatro) y 5 (cinco) estrellas o resorts equivalentes a la categoría de hotel de 5 estrellas y 
restaurantes turísticos de 5 (cinco) tenedores. ${ }^{9}$

Por otro lado, el literal c) del artículo 10 de la LJ dispone que las máquinas tragamonedas y los programas de juego (software de juego) deben cumplir, entre otros, con los siguientes requisitos:

(a) Un porcentaje de retorno al público no menor de $85 \%$ (ochenta y cinco por ciento).

(b) Un generador de números aleatorios.

Cuando la LJ fija como requisito aplicable a todas las máquinas tragamonedas el porcentaje mínimo de retorno al público de $85 \%$ de las apuestas recibidas; implica que de la totalidad de las apuestas recibidas por las máquinas tragamonedas, por lo menos el $85 \%$ de tales apuestas deben retornar al público como premios.

En la realidad, los operadores de casinos y/o salas de máquinas tragamonedas operan con porcentajes de retorno superiores al 85\% exigido por la LJ. En efecto, si bien esta información es mantenida con reserva por los operadores, es conocido que el porcentaje de retorno empleado, usualmente oscila entre el $92 \%$ y el 96\%. La información del retorno que aplica el operador del casino y/o salas de máquinas tragamonedas es declarada por éste a la DGJCMT y a la SUNAT en la Declaración Jurada del IJ.

Recordemos el ejemplo numérico desarrollado en el Capítulo I del presente trabajo, en el que se contempla un porcentaje de retorno ascendente a $95.5 \%^{10}$

Para tal efecto, el porcentaje de retorno al público, es entendido como una fracción del dinero de las apuestas efectuadas en un período determinado, al que usualmente se le denomina "ciclo de juego" y que debe ser devuelto por el programa de juego (software de juego) como premios. Tal porcentaje de retorno al público se determina mediante cálculos matemáticos y estadísticos efectuados por el programa de juegos, que emplea dos variables: (a) La probabilidad de aparición de una combinación ganadora, y (b) el monto del premio.

\footnotetext{
${ }^{9}$ Mediante la Ley N ${ }^{\circ} 28945$ se dictó la "Ley de Reordenamiento y Formalización de la actividad de Explotación de Juegos de Casino y Máquinas Tragamonedas”, mediante la cual se otorgó la posibilidad que aquellas empresas que a la vigencia de dicha norma operaban máquinas tragamonedas sin contar con la autorización de la DGJCMT, pudieran regularizar su situación. Como parte de tal proceso de regularización se liberó a las empresas que se acogían de cumplir con el requisito de operar en los locales de hoteles y/o restaurantes turísticos 5 tenedores.

${ }^{10}$ Se debe reiterar que la información empleada en el ejemplo numérico desarrollado en el Capítulo I y vuelto a citar en este capítulo fue desarrollado gracias a información verdadera brindada por un operador de salas de máquinas tragamonedas autorizado.
} 
La exigencia contenida en la LJ respecto del retorno mínimo, constituye una garantía de transparencia y confiabilidad del juego. Ello debido a que al existir tal porcentaje mínimo obligatorio de retorno, se evita que puedan fijarse porcentajes inferiores o se elimine el retorno al público.

Adicionalmente, el porcentaje mínimo de retorno otorga certeza, al público, que las máquinas tragamonedas en las que se apuesta otorgan la probabilidad de obtener un premio.

Cuando el artículo 10 de la LJ establece la obligación de fijar, en cada máquina tragamonedas, un porcentaje de retorno no menor del $85 \%$ de las apuestas, implica que las apuestas efectuadas no pueden ser asumidas como fondos propios del operador del casino y/o salas de máquinas tragamonedas. Por ello, las apuestas (Coin In) realizadas en un determinado período, no son de libre disposición o titularidad del operador y debe retornar al público el porcentaje que se fije en las máquinas tragamonedas y que no puede ser menor de $85 \%$; lo cual se implementa en la oportunidad y por el monto que determine el software de juego existente en cada máquina tragamonedas.

Al no poder el operador de juego de azar, disponer libremente de la totalidad de las apuestas que recibe (Coin In); se evidencia que las mismas no son de su propiedad y no se incorporan como parte del activo de tal operador.

Por otro lado, el operador de juego de azar siempre debe tener a disposición los montos provenientes de las apuestas (Coin In), ya que el software de juego existente en cada máquina tragamonedas puede otorgar a los jugadores los premios que deben ser honrados. Cabe indicar que la oportunidad en que una máquina tragamonedas otorgará el premio a un jugador, sólo es determinado y conocido por el software de juego de tal máquina tragamonedas; no siendo posible que el operador de juego de azar conozca tal hecho previamente.

Si tenemos presente los dos (2) elementos antes detallados, es decir: (a) El retorno obligatorio de un porcentaje de las apuestas realizadas, y (b) la incertidumbre por parte del operador de juego de azar, respecto del monto y momento en que se otorgarán los premios a los apostadores; permite sostener que los fondos provenientes de las apuestas no son de libre disposición del operador de juego de azar, es decir, tales fondos no son de propiedad del operador, ni forman parte de su activo. 
Atendiendo a ello, resulta factible sostener que el conjunto de las apuestas (Coin In) efectuadas por el público asistente a los casinos y/o salas de máquinas tragamonedas, forman parte de un "Fondo de Juego", que es administrado por el operador de juego de azar y que en el tiempo debe retornar al público participante.

Todo lo antes expuesto, se corrobora con diversas disposiciones contenidas en la LJ y que a continuación se detallan:

(a) Artículos 19, 20 y 21 de la LJ, según los cuales los operadores de casinos y/o salas de máquinas tragamonedas se encuentran obligados a constituir una garantía a favor del MINCETUR, en respaldo de las obligaciones y sanciones derivadas de la aplicación de la LJ y en resguardo de los derechos de los usuarios y el Estado, excepto lo regulado por el CT.

Una de las finalidades que busca cubrir la garantía exigida a los operadores de casinos y/o salas de máquinas tragamonedas son los derechos de los usuarios, dentro de los cuales se encuentra garantizar la entrega de los premios que se generen y que provienen del Fondo de Juego.

(b) El literal c) del artículo 31 de la LJ establece que los operadores de casinos y/o salas de máquinas tragamonedas se encuentran obligados a "cancelar de inmediato el pago correspondiente al usuario-ganador, así como canjear en efectivo las fichas o cualquier otro medio que posibilite la jugada".

De la norma antes detallada, se desprende que los operadores deben entregar a los apostadores ganadores los premios (Coin Out), de forma inmediata y efectuar el canje en efectivo de los medios de juego. Esta obligación se encuentra acorde con el hecho que el operador, en su calidad de administrador del Fondo de Juego, debe tener permanentemente a su disposición tal Fondo de Juego, para cubrir los requerimientos de entrega de los premios.

(c) Mediante las Resoluciones Directorales No 0488-2002-MITINCI/VMT/DNT y 017-2004-MINCETUR/VMT/DNT se establecen las disposiciones para la culminación de un pozo acumulado. Para ello, las normas indicadas definen por:

(i) "Pozo Acumulado" al pozo autorizado por la DGJCMT para su funcionamiento en mesas de juego de casino. 
(ii) "Bono progresivo": A la apuesta adicional voluntaria realizada por el jugador de una modalidad de juego de casino a efecto de participar y eventualmente acceder a cualquiera de los premios establecidos en la tabla de pagos correspondiente con cargo al pozo acumulado.

Por otro lado, las normas en mención establecen que si un operador de casinos cesa permanentemente sus actividades; los pozos acumulados que existan deben ser transferidos, por el titular, a una cuenta especial del Banco de la Nación a nombre del MINCETUR, denominada: "Pozo Acumulados - Sala de Juego de Casino", a efecto que mediante un sorteo ante Notario Público designado por la DGJCMT se transfiera el pozo acumulado a la sala de juegos que resulte beneficiada con dicho sorteo. De esta norma se evidencia que nos encontramos ante un Fondo de Juego que no es de propiedad del operador autorizado por la DGJCMT.

De la norma antes detallada se desprende que el pozo acumulable (fondo de juego) subsiste aún después que un operador de casino concluya sus operaciones y es transferido, vía sorteo, a otra empresa operadora de casino. Con ello queda claro que el Fondo de Juego no es de titularidad del operador, siendo este último un administrador del mismo.

En consecuencia, la totalidad de las apuestas efectuadas en un casino y/o sala de máquinas tragamonedas, ingresan a un Fondo de Juego que no es de libre disposición del operador y que debe ser administrado para garantizar el retorno mínimo exigido por la LJ. En tal sentido, la contraprestación obtenida por los operadores de casino y/o salas de máquinas tragamonedas, es decir, los fondos que son de su libre disposición, son el diferencial (Net Win), resultante de restar al total de apuestas (Coin In), el total de los premios pagados (Coin Out) y que usualmente en tal actividad se detalla de la siguiente manera:

\section{COIN IN - COIN OUT $=$ NET WIN \\ APUESTAS - PREMIOS = INGRESO}

Siguiendo el criterio antes detallado, la LJ aprobó un impuesto especial para tal actividad denominado "Impuesto a la Explotación de los Juegos de Casino y Máquinas Tragamonedas" (IJ). 
El artículo 38 de la LJ al regular el IJ, recoge los conceptos antes vertidos y dispone que la base imponible del IJ se encuentra conformada por la diferencia entre el ingreso neto mensual y los gastos por mantenimiento de las máquinas tragamonedas y medios de juego de casinos. Para tal efecto, el literal a) del numeral 38.2 de la LJ define por "Ingreso Neto Mensual" a "la diferencia entre el monto total recibido por las apuestas o dinero destinado al juego y el monto total entregado por los premios otorgados en el mismo mes."

Si bien la definición de "Ingreso Neto Mensual", es aplicable sólo al IJ; tal como lo manifestó SUNAT en el Oficio No 211-2006-SUNAT/2B0000; sin embargo, tal concepto contenido en la LJ, permite analizar y determinar la naturaleza jurídica tributaria del:

- “Coin In" (apuesta),

- "Coin Out y Hand Pay" (premios), y

- "Net Win" (remanente a favor del operador del casino y/o sala de máquinas tragamonedas).

Si lo antes indicado es complementado con las disposiciones del artículo 10 de la LJ, referido al retorno mínimo obligatorio que fue tratado en el presente numeral, permiten concluir que el Net Win califica como ingreso.

\subsection{Problemática de los anticipos de la tercera categoría del IR en la actividad de casinos y salas de máquinas tragamonedas}

Como parte de la labor fiscalizadora de la Administración Tributaria (SUNAT), desde el año 2008 en adelante, se formularon observaciones a la base de cálculo de los anticipos de tercera categoría del/IR de los operadores de casinos y salas de máquinas tragamonedas.

En efecto, las observaciones a la determinación a los anticipos de tercera categoría del IR se sustentaban, en que la base de cálculo debía efectuarse sobre la totalidad de las apuestas (Coin In) efectuadas por los clientes en los casinos y/o salas de máquinas tragamonedas durante el periodo mensual. Ello debido a que la Administración Tributaria consideraba que las apuestas (Coin In) calificaban como ingresos y sostuvo que las normas de la LJ no debían ser consideradas para determinar lo que califica como ingreso 
de dicha actividad. La posición esgrimida por la Administración Tributaria fue inicialmente sustentada con el Informe No 211-2008-SUNAT/2B0000.

Esta problemática se originó debido a que el artículo 85 de la LIR y el numeral 3 del literal a) del artículo 54 de la RLIR establecen que los anticipos de tercera categoría deben ser determinados "sobre la base de los ingresos netos obtenidos en el mes; debiendo entenderse por ingresos netos al total de ingresos gravables de la tercera categoría devengados en cada mes, menos las devoluciones, bonificaciones, descuentos y demás conceptos de naturaleza similar que respondan a la costumbre de la plaza, excluyéndose expresamente al resultado por exposición a la inflación.”

Atendiendo a ello, los anticipos de la tercera categoría del IR se determinan sobre la base del ingreso gravable y devengado en el mes. Por lo cual, la base imponible de los anticipos de la tercera categoría del IR deben:

(a) Calificar como ingreso.

(b) El ingreso debe encontrarse comprendido en la tercera categoría del IR.

(c) El ingreso de la tercera categoría debe encontrarse devengado.

Ahora bien, como ya indicamos, las disposiciones del IR no contienen una definición de lo que debe entenderse por "INGRESOS".

Como he sostenido en la presente investigación, el concepto de ingreso constituye uno de carácter estrictamente contable que es recogido en las disposiciones del IR. En efecto:

Si admitimos que el concepto de renta es, en el caso de las empresas, un concepto contable y que dicho concepto es un resultado obtenido de la comparación de ingresos y costos, resulta imprescindible comprender el concepto de ingreso desde el punto de vista de las ciencias contables (Villanueva Gonzáles, 2004, p. 6).

Por ello, en el capítulo IV de la presente investigación se analizará el concepto de ingreso y la interacción entre las normas contables y las normas tributarias; para poder determinar si los conceptos vertidos en el MC y en la NIC 18 resultan aplicables para efectos tributarios.

Por otro lado, la posición esgrimida por los operadores de casinos y/o salas de máquinas tragamonedas contenía dos argumentos que desarrollamos a continuación: 
(a) Net Win como ingreso: Se planteó que el "ingreso", para efecto de determinar los anticipos de tercera categoría del IR, es el diferencial (Net Win) de restar a las apuestas (Coin In), los premios (Coin Out) entregados en el mismo periodo.

Tal posición fue sustentada en base a: (i) la obligación de retorno mínimo al público del $85 \%$ de las apuestas (Coin In) efectuadas, conforme al artículo 10 de la LJ; (ii) el concepto de ingreso neto mensual existente en el literal a) del numeral 38.2 del artículo 38 de la LJ, que contiene conceptos que permiten definir cuál es el ingreso derivado de la actividad de casinos y/o salas de máquinas tragamonedas, (iii) las disposiciones contenidas en el MC y la NIC 18 según las cuales el Net Win cumple con las exigencias de las normas contables para ser calificado como ingreso.

(b) Coin In como ingreso: En el negado caso que el Coin In hubiera calificado como ingreso, para efectos de los anticipos de tercera categoría del IR; debe tenerse presente que el artículo 85 de la LIR establece que la base imponible de los anticipos se encuentran constituidas por el ingreso neto devengado en el mes, menos las devoluciones, bonificaciones, descuentos y demás conceptos de naturaleza similar que respondan a la costumbre de la plaza.

Atendiendo a ello, se admiten como conceptos que pueden ser deducidos del ingreso neto, a las devoluciones, bonificaciones, descuentos, y demás conceptos de naturaleza similar que respondan a las costumbres de la plaza.

Cabe indicar que el penúltimo párrafo del artículo 85 de la LIR al hacer expresa mención a "demás conceptos de naturaleza similar que respondan a las costumbres de la plaza", abre la posibilidad de deducir conceptos que por su naturaleza no califiquen como devoluciones, bonificaciones, descuentos, pero que por el tipo de actividad resulte evidente que tal rubro constituye una reducción usual y necesaria para que el contribuyente obtenga los ingresos netos afectos al anticipo de tercera categoría del IR.

En el caso que nos ocupa, los premios ("coin out" y "hand pay") constituyen rubros que forman parte de la propia naturaleza de la actividad y que sin ellos los juegos de azar no existirían. Ello implica que los premios se originan por la propia costumbre de la plaza. Sin perjuicio de lo antes detallado, tales premios y los porcentajes mínimos de retorno constituyen obligaciones legales contenidas en la LJ. 
En consecuencia, la naturaleza jurídica de los premios ("coin out" y "hand pay") permite calificarlos como un rubro que se encuentra contenido en "demás conceptos de naturaleza similar que respondan a las costumbres de la plaza"; por lo cual, deben ser deducidos del ingreso neto empleado para determinar los anticipos de la tercera categoría del IR.

Sin perjuicio de lo antes indicado, las salas dos y cinco del Tribunal Fiscal en las RTFs N ${ }^{\circ}$ 00908-2-2016, 01879-2-2016, 02099-5-2016 y 02100-5-2016, brindaron los siguientes conceptos:

(i) "Rebaja": En las RTFs No No 6725-2-2014 y 09688-1-2004 se precisa que la rebaja es una "disminución sobre el precio habitual de venta que una empresa concede a sus clientes y una forma de incentivar, en el largo o en el corto plazo, la compra de sus productos y la fidelidad de sus clientes."

(ii) "Bonificaciones": El Tribunal Fiscal en la RTF No 8049-3-2010 establece que "las bonificaciones sobre ventas corresponden a las rebajas que se conceden sobre el precio de venta, independientemente de las fechas de vencimiento de los pagos respectivos y añade que se entiende la bonificación como una ventaja en las transacciones realizadas, equivalente a una prima, comisión o rebaja."

(iii) "Conceptos de naturaleza similar que respondan a las costumbres de la plaza": En tal concepto "sólo deben incluirse supuestos que, aunque con otra denominación, impliquen una rebaja sobre el pago que debe efectuarse por la transacción."

Por ello, el Tribunal Fiscal concluye que:

El otorgamiento de premios por parte de las empresas dedicadas a la explotación de juegos de casino y máquinas tragamonedas, no busca rebajar o disminuir las sumas de dinero que entregan sus clientes por las operaciones que efectúan con ellas, sino que constituyen una contraprestación aleatoria a sus apuestas, no procede considerar los montos de tales premios como devoluciones, bonificaciones, descuentos o demás conceptos de naturaleza similar que respondan a la costumbre de la plaza (...) 
Por otro lado, en el capítulo V referido a los "Pronunciamientos", se puede apreciar que la Administración Tributaria mediante los Informes No 188-2015-SUNAT/5D0000 y 0022017-SUNAT/5D0000 varió la interpretación inicialmente formulada en las fiscalizaciones, considerando que los conceptos vertidos en el MC y en la NIC 18 resultaban aplicables y que el ingreso en la actividad de casinos y salas de máquinas tragamonedas se encuentra dado por la diferencia entre las apuestas realizadas en el mes (Coin In) y los premios pagados en el mismo periodo (Coin Out).

Paradójicamente, aun cuando la opinión de la Administración Tributaria y de los contribuyentes no resulta discrepante (después de la emisión del Informe $\mathrm{N}^{\circ}$ 188-2015SUNAT/5D0000), existen procedimientos administrativos en los que el Tribunal Fiscal no tuvo en cuenta la opinión vertida por SUNAT en el Informe antes indicado y se emitieron las RTFs No 00908-2-2016, 01879-2-2016, 02099-5-2016 y 02100-5-2016, en las que el órgano colegiado se adhirió a la posición inicialmente formulada por SUNAT en las fiscalizaciones.

Por otro lado, tales RTFs han sido judicializadas (demandas contenciosas administrativas) habiéndose obtenido ya una sentencia en primera instancia favorable a los contribuyentes y que será analizada en el capítulo V. 


\section{CAPÍTULO III: ANTICIPOS DEL IMPUESTO A LA}

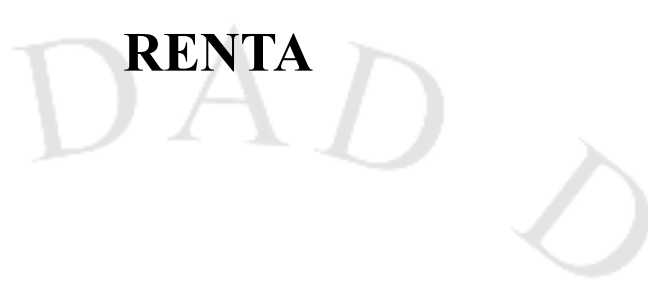

\subsection{Precisión terminológica}

En el presente capítulo se analiza la figura jurídica tributaria denominada "anticipos", como aquel mecanismo recaudatorio cuya finalidad es "cubrir la necesidad financiera del Estado de contar con recursos a lo largo del período para poder solventar el gasto público."11 Tal mecanismo de recaudación anticipada también es conocido en otras latitudes como "pagos a cuenta", "ingresos a cuenta", "pagos fraccionados"1213, "pagos anticipados" 14 y "adelantos".

En la legislación peruana los anticipos son denominados "pagos a cuenta" y se encuentran recogidos en la LIR. Sin embargo, debemos preguntarnos si la denominación otorgada a tal mecanismo de recaudación anticipada resulta ser exacta y correcta.

El término "pagos a cuenta" proviene de un concepto previo ampliamente desarrollado por la doctrina y legislación civil y que es el concepto del "pago".

En efecto, en el derecho civil la figura del "pago" es entendida como una modalidad de extinción de las obligaciones; de ello se desprende implícitamente que

11 Resolución del Tribunal Fiscal No 796-2-2001.

12 Este término también es empleado en el artículo 27 del Modelo de Código Tributario del CIAT (Mayo 2015), como se detalla a continuación:

\section{"Artículo 27. Obligados a realizar pagos a cuenta o anticipados}

Está llamado a realizar pagos fraccionados, el obligado tributario cuando la ley de cada tributo le impone el deber de ingresar cantidades a cuenta de la obligación tributaria principal con anterioridad a que ésta resulte exigible."

13 Término empleado en el artículo 23 de la Ley General Tributaria del Reino de España, como se detalla a continuación:

\section{“Artículo 23. Obligación tributaria de realizar pagos a cuenta}

1. La obligación tributaria de realizar pagos a cuenta de la obligación tributaria principal consiste en satisfacer un importe a la Administración tributaria por el obligado a realizar pagos fraccionados, por el retenedor o por el obligado a realizar ingresos a cuenta.

Esta obligación tributaria tiene carácter autónomo respecto de la obligación tributaria principal.

2. El contribuyente podrá deducir de la obligación tributaria principal el importe de los pagos a cuenta soportados, salvo que la ley propia de cada tributo establezca la posibilidad de deducir una cantidad distinta a dicho importe."

Término empleado en el artículo 45 del Modelo de Código Tributario para América Latina OEA/BID. 
siempre antes de configurarse el "pago" debe pre existir una obligación y que es el cumplimiento de una prestación debida, generando la satisfacción del interés del acreedor.

Ante ello, cabe preguntarnos si cuando un contribuyente cumple mensualmente con habilitar a la Administración Tributaria los fondos exigidos, para cumplir con los pagos a cuenta de la LIR, se está extinguiendo la obligación tributaria derivada del IR. Coincidirán en que la respuesta resulta ser manifiestamente clara, tal habilitación de fondos a favor de la Administración Tributaria no extingue la obligación tributaria del IR, ya que ésta última no existe a dicha fecha y sólo se configurará al final del ejercicio gravable, en tanto los resultados que se obtengan sean positivos.

De acuerdo con Luque Bustamante (1988),

el cumplimiento de estas obligaciones constituye "pago" en cuanto extingue dichas obligaciones independientes, pero no lo es respecto de la obligación del Impuesto a la Renta que nacerá al final del ejercicio. En efecto, el pago es una forma de extinguir obligaciones y, no puede extinguirse obligaciones no nacidas o que incluso podrían no nacer nunca. Por ello jurídicamente sólo puede hablarse de "pagos anticipados" respecto de obligaciones nacidas pero en las que todavía no se cumplió el plazo para hacerlas exigibles (p. 3).

Por ello, se evidencia que términos tales como "Pagos a Cuenta", "Pagos Fraccionados" y "Pagos Anticipados" contienen conceptos disimiles a los términos "Anticipos”, “Ingresos a Cuenta”, “Adelantos”. Siendo esto así, para el correcto desarrollo del presente trabajo empleo el término "Anticipo", ya que representa uno de los fines buscados por tal mecanismo recaudatorio y que es poder brindar recursos a la Administración Tributaria de forma previa a la generación de la obligación tributaria.

A manera de primera conclusión, aun cuando el desembolso puede calificar como pago del mecanismo recaudatorio anticipado denominado pago a cuenta, no lo es respecto del IR; por ello, no resulta técnico, ni correcto emplear el término "pago" como parte de las denominaciones atribuidas a los mecanismos de recaudación anticipada objeto de análisis del presente trabajo. Todos aquellos términos como "Pagos a Cuenta", "Pagos Fraccionados" y "Pagos Anticipados" resultan ser errados y no reflejan la verdadera naturaleza de los mecanismos de recaudación anticipada.

\subsection{Justificación o necesidad de los anticipos}


Como parte de las actividades propias del Estado, éste incurre en gasto público el cual puede ser clasificado como (a) gasto corriente y (b) gasto de capital.

Ferreiro Lapatza (2010) define al "gasto corriente" o también conocido como "gasto ordinario" como aquel que "respondían a la actividad normal y habitual del Estado, a su funcionamiento general, y se repetían cada año.” (p. 73) Este mismo autor sostiene que los gastos de funcionamiento o también denominados corrientes son los normales para la operación del Estado, tales como los servicios públicos, pago de personal y conservación o mantenimiento de sus bienes.

Por otro lado, Ferreiro Lapatza define por "gastos de capital" a aquellos que “afectan a la riqueza de la nación, a su capital y no a sus rentas; son por ejemplo, los gastos de inversiones, de instalación, de reconstrucción, etc.” (p. 73)

Ahora bien, este mismo autor sostiene que "lógicamente el gasto es anterior al ingreso, pues es la necesidad de gastar lo que justifica los ingresos.” (p. 72)

En lo referente a los ingresos que obtiene el Estado, De Juano (1969) entiende por "ingresos públicos" a aquellos "bienes o sumas de dinero que obtiene el Estado en propiedad para emplearlos legítimamente en la satisfacción de las necesidades públicas." (p. 141)

Giuliani Fonrouge (1993) ensaya una clasificación de ingresos en función a las distintas y diferentes actividades ejercitada por el Estado, clasificándolos en (i) provenientes de bienes y actividades del Estado (producido por bienes de dominio de empresas y servicios públicos e industriales y comerciales) y (ii) los provenientes del ejercicio de poderes inherentes a la soberanía o al poder de imperio (tributos, sanciones fiscales, crédito público y moneda). (p. 224)

De todo lo antes indicado, se aprecia que para el correcto funcionamiento del Estado, es necesario que éste obtenga de forma fluida y constante ingresos públicos, siendo una fuente de éstos, las obligaciones tributarias impuestas a los contribuyentes en virtud del ius imperium.

En la legislación nacional no existe una definición del término "tributo", limitándose a desarrollar la clasificación tripartita de los tributos. En efecto, la Norma II 
del Título Preliminar del $\mathrm{CT}^{15}$, los tributos pueden clasificarse en (a) impuestos, (b) tasas, y (c) contribuciones.

En el caso específico de los "impuestos", Villegas (1987) los define como "el tributo exigido por el Estado a quienes se hallan en las situaciones consideradas por la ley como hechos imponibles, siendo estos hechos imponibles ajenos a toda actividad estatal relativa al obligado.” (p. 72)

En efecto, en los impuestos de periodicidad anual, en algunos casos la obligación tributaria puede originarse al inicio del ejercicio como es el caso del Impuesto Predial o la obligación tributaria puede configurarse al concluir el ejercicio como en el caso del Impuesto a la Renta.

En los impuestos de periodicidad anual, cuya obligación tributaria surge al final del ejercicio gravable (IR), la obligación tributaria se configura cuando se completa el período anual (12 meses); sin embargo, luego de ello el contribuyente debe cumplir con presentar la declaración tributaria en la que se determina la obligación en mención; lo que normalmente sucede después de haber transcurrido un plazo adicional de tres meses (que es el plazo máximo para la presentación de la declaración de tal impuesto). Acorde con el segundo párrafo del numeral 1 artículo 3 del CT, la obligación tributaria resulta exigible desde el día siguiente al vencimiento del plazo fijado en el cronograma de pago fijados por SUNAT. Ello implica que desde la fecha en que la obligación tributaria es exigible, la Administración Tributaria puede exigirla compulsivamente.

Lo detallado en el párrafo precedente implica que el Estado vía la Administración Tributaria debe esperar aproximadamente quince meses ${ }^{16}$ para poder percibir la recaudación derivada del IR. Ello genera una distorsión para el Estado, ya que, supuestamente, durante el plazo en que no resulta exigible el IR, el Estado no recibiría recaudación alguna por concepto del IR. Ello perjudicaría la necesidad constante del Estado de cubrir parte del gasto público.

Ferreiro Lapatza (2010) manifiesta que:

\footnotetext{
15 Aprobado por el Decreto Legislativo N ${ }^{\circ}$ 816, publicado en el diario oficial "El Peruano" del 21 de abril de 1996; cuyo Texto Único Ordenado (TUO) fue aprobado por el Decreto Supremo No 133-2013-EF, publicado en el diario oficial "El Peruano" del 22 de junio de 2013.

$16 \quad$ Los 15 meses son el resultado de sumar: (i) los 12 meses del período anual para que se configure la obligación tributaria del IR; y, (ii) los 3 meses del plazo máximo para la presentación de la declaración del IR.
} 
el Estado no puede ni considera conveniente esperar a recibir anualmente el impuesto que grava la renta que obtienen los sujetos pasivos contribuyentes durante todo el año. El Estado necesita flujos continuos de ingresos y necesita, además, facilitar y asegurar el pago de los impuestos anuales sobre la renta (p. 335).

Como resulta evidente, tal distorsión que afecta al Estado por los impuestos de periodicidad anual cuya obligación tributaria surge al final del ejercicio (IR), resulta inaceptable. García Mullín (1978) indica que tales razones de carácter financiero y administrativo obligan al Estado a idear fórmulas que permitan obtener mayor liquidez y reduzcan el plazo de espera, surgiendo el sistema que denomina "pague a medida que gane" o "pay as you earn" que se desarrolla o ejecuta mediante dos mecanismos: (a) las retenciones, y (b) los anticipos (p. 171-172). Tales mecanismos también podemos denominarlos "mecanismos de recaudación anticipada" y que en virtud del Ius Imperium del Estado, éste los impone para obtener de forma fluida y constante, durante todo el año, los ingresos públicos que permitan solventar los gastos que debe cubrir el Estado.

En efecto, Luque (1989) sostiene que los anticipos tienen "como causa o razón económica la necesidad de anticipar al Estado los ingresos que obtendrá al final del ejercicio por concepto del impuesto definitivo.” (p.123)

Respecto de los anticipos, García Mullin (1978) indica que éstos:

constituyen obligaciones creadas por la ley en forma paralela a la obligación tributaria sustantiva (que se devenga solamente al final del período) y buscan que antes de devengarse la obligación, el contribuyente ya vaya ingresando fondos, como típica respuesta del ordenamiento jurídico al problema de la concentración de ingresos en una sola época de vencimiento fiscal, y también, en países con inflación, como forma de precaverse de la pérdida de valor de las obligaciones en moneda expuesta a desvalorización (p. 173).

En efecto, los "anticipos" constituyen mecanismos de recaudación anticipada que se implementan, usualmente, en tributos de periodicidad anual, para habilitar al Estado de ingresos, reduciendo el riesgo del tiempo para obtener recaudación.

Adicionalmente a lo detallado en el párrafo precedente, los “anticipos" tienen por finalidad facilitar a los contribuyentes el pago de la obligación tributaria (impuesto), permitiéndose el pago de adelantos y evitando que al momento de la determinación y pago del impuesto el contribuyente pueda verse afectado en su liquidez por el pago de montos muy elevados. 
Gil Cruz (2010), sostiene que los anticipos cuentan con una doble finalidad, "De un lado facilitar una mejor gestión en el cumplimiento del pago del Impuesto por parte de los sujetos pasivos y de otro, permitir la necesaria liquidez a la Hacienda Pública para que pueda hacer frente a los diversos gastos públicos"

De igual forma, Mares Ruiz (2008) al citar el preámbulo del Real Decreto 2789/1978 establece que:

Son dos las razones que se anotan en el preámbulo de esta norma para justificar la existencia de los pagos a cuenta. Desde la perspectiva de la Administración, se consigue acercar el momento de la imposición a la generación efectiva de la renta; desde la perspectiva del contribuyente, se aligera el esfuerzo que supone el pago del gravamen al final del ejercicio y se evita así el riesgo de incumplir la obligación tributaria por falta de liquidez (p. 67).

Adicionalmente, existen autores como García Berro (2013) que le atribuyen a los anticipos una tercera finalidad que es “... la Hacienda Pública encuentra en el sistema de pagos a cuenta un mecanismo insustituible de obtención de información, pues su ingreso ha de ir acompañado de los datos que permiten identificar a los perceptores de las rentas afectas, así como la cuantía y la naturaleza de estas últimas. Y ello sin despreciar la importancia de los ingresos anticipados que genera el sistema, como medio de proporcionar liquidez al Erario Público.” (p. 302)

\subsection{Características de los anticipos}

A continuación, desarrollo las características que se desprenden de los “anticipos":

- Son obligaciones legales (ex lege): En efecto, los “anticipos" son obligaciones ex lege, es decir, obligaciones que son creadas por ley. Los anticipos "son el objeto de una relación jurídica obligatoria ex lege, la cual se instaura al producirse el acaecimiento de la hipótesis de incidencia o presupuesto de hecho de la ley." (Bravo Cucci, 2013, p. 305)

- Son anteriores a la existencia del impuesto: Los "anticipos" constituyen obligaciones que son ejecutadas con anterioridad a la existencia o configuración, determinación y declaración de la obligación tributaria; sin embargo, guarda directa vinculación con la misma. Por lo cual, la determinación de tales obligaciones legales debe efectuarse tomando como referencia una capacidad 
presunta del sujeto obligado y que se logra tomando como referencia los resultados, ingresos y el impuesto del ejercicio anterior.

- Son anticipos de un futuro y probable impuesto: Los anticipos se determinan en base a criterios de capacidad contributiva presunta, ya que se estructuran sobre criterios estadísticos de ejercicios anteriores tales como los resultados del ejercicio anterior, el impuesto pagado en el ejercicio anterior, etc. Sin embargo, no existe la plena certeza que llegue a configurarse la obligación tributaria (impuesto) al final del ejercicio.

- El "anticipo está determinado totalmente por factores que corresponden a períodos gravables anteriores a aquél en que debe ser aplicado, por lo cual resulta evidente que no consulta la realidad económica del sujeto pasivo.” (Bravo Arteaga, 2012) Es por ello, que para evitar distorsiones que este mecanismo de recaudación anticipada puede generar, se contemplan supuestos en los que el contribuyente, amparado en hechos objetivos, puede solicitar reducción de los mismos e incluso su suspensión.

- Es una obligación legal independiente respecto del impuesto y en la que existe coactividad: "Es una obligación tributaria independiente (...), en cuanto la base cálculo, la determinación y la oportunidad de pago son distintas." (Villanueva Gutiérrez, 2003, p. 14); y existe coactividad debido a que tal obligación es impuesta y exigible por el Estado en función de su Ius Imperium.

- Es una obligación provisional: Si bien los "anticipos" son exigibles por la Administración Tributaria, tal exigibilidad sólo existirá en tanto la obligación tributaria (impuesto) no se encuentre determinada. Ejemplo de ello se evidencia del primer párrafo del artículo 34 del CT, según el cual:

- "El interés moratorio correspondiente a los anticipos y pagos a cuenta no pagados oportunamente, se aplicará hasta el vencimiento o determinación de la obligación principal."

- Por el contrario, los impuestos califican como obligaciones definitivas y cuya existencia y vigencia no estará limitada por otro factor. Es por ello, que en la doctrina es usual que los definan como obligaciones accesorias o subsidiarias de una principal (impuesto). 
- Son vinculadas a una obligación tributaria (impuesto): "La cuantía del pago a cuenta -por su propia razón de ser - debe ser razonablemente aproximada al monto del tributo principal." (Villanueva Gutiérrez, 2003, p. 15)

\subsection{Naturaleza Jurídica de los "anticipos"}

Tal como fue mencionado en el numeral 3.3 precedente, los "anticipos" constituyen obligaciones legales impuestas a los contribuyentes en virtud del Ius Imperium del Estado. Sin embargo, no existe una posición unánime, ni pacífica respecto de si tales obligaciones son de carácter tributario o no. En efecto, en la doctrina tributaria nacional y extranjera existen amplias controversias sobre el particular y en gran parte de los ordenamientos tributarios no se ha optado por definir la naturaleza de los mismos.

Ahora bien, en lo que existe uniformidad de criterio es la necesidad de obtener una respuesta a esa interrogante, ya que la conclusión que se obtenga generaría efectos relevantes en el tratamiento de los "anticipos".

En la doctrina tributaria, existen las siguientes posiciones respecto de los "anticipos":

(a) Los "anticipos" como obligaciones legales no tributarias.

(b) Los "anticipos" como obligaciones legales tributarias.

A continuación, desarrollamos cada una de ellas:

(a) Los "anticipos" como obligaciones legales no tributarias:

En la doctrina nacional algunos autores, como Bravo Cucci (2013), entienden que los anticipos no son obligaciones jurídicas tributarias, pues el objeto de las mismas necesariamente es un tributo y en el caso de los anticipos ello no se cumple. (p. 311)

A efectos de arribar a esa conclusión, resulta pertinente determinar qué se entiende por tributo.

Sobre el particular, la Norma II del Título Preliminar del CT no contiene una definición de lo que debe entenderse por "tributo", limitándose a brindar una clasificación tripartita de los tributos (impuestos/tasas/contribuciones). Atendiendo a ello, cualquier modalidad distinta a los impuestos, tasas y contribuciones no puede ser calificada como tributo. 
Una primera definición de “tributo” es la planteada por Ataliba (1987), según la cual:

jurídicamente, se define al tributo como una obligación jurídica pecuniaria ex lege, que no constituye sanción de acto ilícito, cuyo sujeto activo es, en principio, una persona pública, y cuyo sujeto pasivo es alguien puesto en esa situación por la voluntad de la ley (p. 37).

En torno al concepto de tributo, Sotelo y Vargas (1998) consideran que “(...) el tributo (...) es una prestación generalmente pecuniaria y exigida con la finalidad principal de obtener recursos, que es el contenido de una obligación ex lege, cuyo sujeto activo es, en principio, una persona pública, y su sujeto pasivo es alguien puesto en esa situación por la voluntad de la ley (...).” (p. 301)

Por su parte, Bravo Cucci señala que por tributo debe entenderse:

aquella prestación de dar de naturaleza pecuniaria que no constituya sanción por acto ilícito, cuyo cumplimiento es dispuesto por la instauración de una relación jurídica obligatoria ex lege (deber jurídico de prestación tributaria), como producto del acaecimiento de una hipótesis de incidencia tributaria, y cuyo sujeto activo es en principio, un ente de derecho público (p. 311).

Asimismo, este autor agrega que "No puede haber -y somos enfáticos en ello- una relación jurídica tributaria cuyo objeto no sea un tributo." (p. 311)

En tal sentido, en caso de existir una obligación cuyo objeto no es un tributo, ésta no podría ser calificada como una de carácter tributario. En esta línea, Bravo Cucci (2013) sostiene que:

"i. Los pagos a cuenta son prestaciones pecuniarias que no se ajustan a la naturaleza de alguna de las especies tributarias tal como se encuentran definidas en la legislación peruana. En tal sentido se puede concluir que los pagos a cuenta no son tributos para el Sistema Tributario Peruano.

ii. Tales prestaciones son objeto de una relación jurídica obligatoria que se origina por el acaecimiento en el plano fáctico, de un soporte hipotético contenido en una norma jurídica. Tal relación jurídica obligatoria no es tributaria ni mucho menos califica como un deber formal.

iii. La naturaleza de los pagos a cuenta es asimilable a la de los empréstitos forzosos." (p. 317) 
Cabe mencionar que SUNAT en el Informe No 314-2002-SUNAT/K00000 asume una posición idéntica a la detallada líneas arriba manifestando que:

puede afirmarse que el pago a cuenta, conceptualmente, es sólo el cumplimiento anticipado de la obligación o abono de dinero sujeto a liquidación posterior, el cual no constituye en sí mismo un tributo ${ }^{(2)}$, sino un pago sujeto a la regularización de la obligación principal, como lo es el caso del Impuesto a la Renta establecido anualmente. La obligación de efectuar pagos a cuenta, entonces, si bien se distingue de la obligación derivada del tributo mismo, existe solo por su carácter instrumental, cuyo efecto práctico es el beneficio que obtiene el acreedor tributario debido al costo de oportunidad originado en la anticipación del ingreso que, de otro modo, debería ser recién satisfecho cuando se presente la declaración-liquidación del tributo.

Incluso en la nota de pie de página existente en el texto transcrito en el párrafo precedente se cita lo siguiente: "Cabe indicar, que conforme a lo dispuesto en la Norma II del TUO del Código Tributario, el término genérico tributo comprende impuesto, contribución y tasa." Atendiendo a ello, se evidencia que SUNAT considera que los "anticipos" no constituyen obligaciones tributarias, ya que las únicas que pueden ser calificadas como tales son las detalladas en la Norma II del Título Preliminar del CT (impuesto, tasa y contribución).

Por otro lado, de los considerandos de la RTF $N^{\circ}$ 04184-2-2003 del Tribunal Fiscal, se puede inferir que en tal resolución el órgano colegiado consideró que los "anticipos" no calificaban como obligaciones tributarias, tal como se desprende de los textos que a continuación transcribimos:

El segundo párrafo del artículo $65^{\circ}$ del citado Código, señala que "la aplicación de las presunciones será considerada para efectos de los tributos que constituyen el Sistema Tributario Nacional (...).

\section{$(\ldots)$}

De las normas antes glosadas se genera una duda respecto de la procedencia de la adición a la base de cálculo de los pagos a cuenta de los ingresos determinados sobre base presunta, en aplicación de las presunciones establecidas por los artículos $66^{\circ}$ a $72^{\circ}$ del Código Tributario y por los artículos $52^{\circ}, 92^{\circ}$ a $96^{\circ}$ de la Ley del Impuesto a la Renta.

Dicho asunto fue materia de acuerdo de Sala Plena según consta en el Acta de Reunión de Sala Plena $N^{\circ}$ 2003-13 de 7 de julio de 2003, habiéndose adoptado como criterio 
que "no procede adicionar a la base de cálculo de los pagos a cuenta del Impuesto a la Renta, las presunciones establecidas en el Código Tributario y en la Ley del Impuesto a la Renta para la determinación anual.

Si bien en la RTF No 04184-2-2003 no hace expresa mención a que los "anticipos" no constituyen obligaciones tributarias; el hecho que las presunciones del artículo 65 del CT sólo sean de aplicación a tributos y el hecho que el Tribunal Fiscal determine que tal norma no es de aplicación para los "anticipos", se genera por el hecho de no considerar como obligaciones tributarias a los "anticipos".

Continuando el análisis de esta posición, la doctrina que califica a los anticipos como obligaciones legales no tributarias; entienden a los anticipos como una figura jurídica cuya naturaleza es la de los empréstitos forzosos. Ello debido a que en los mismos existe la obligación legal de prestar una determinada cantidad de dinero al Estado, por un plazo determinado, a cambio del pago de un determinado interés; y, existe la obligación del Estado de devolver el monto prestado al prestamista.

En efecto, para Bravo Cucci (2013), los anticipos tienen la naturaleza jurídica de los empréstitos forzosos, figura con la cual guardan relación de género a especie (p. 316). Dicha conclusión, en su opinión, se debería a que la obligación de efectuar el empréstito forzoso a favor del Estado es establecida por ley, de manera unilateral, sin considerar la voluntad del sujeto obligado a cumplir la misma.

Bravo Cucci cuando fundamenta su posición recoge lo expuesto por Luque y Padrón (1989) respecto a que los anticipos son adelantos que tienen las características de una especie de empréstito forzoso en favor del sujeto al que corresponde el anticipo, por cuanto “(...) al igual que éste, es un vínculo personal, pecuniario, nacido por la voluntad unilateral del Estado, a través de un mandato legal y exigible coactivamente, con la obligación de devolver en un plazo determinado (...)” (p. 160); sin embargo, éstos últimos autores difieren de la posición asumida por Bravo Cucci, ya que ellos si le reconocen una naturaleza tributaria a los mismos, señalando que "(...) constituyen obligaciones tributarias sustantivas independientes de la obligación del impuesto definitivo (...)” (p. 159).

La jurisprudencia de la Corte Suprema de Justicia de la República (CAS. № 43922013 LIMA) asumió una posición similar a la detallada en los párrafos precedentes, estableciendo que: 
Un elemento trascendental a efectos de establecer cuál es la naturaleza de los pagos a cuenta, es la restitución del monto recaudado, lo cual se encuentra regulado en el artículo 87 segundo párrafo, de la Ley del Impuesto a la Renta, la cual forma parte de la configuración de los empréstitos forzosos, siendo ajena a los elementos estructurales del tributo, anotados precedentemente; por lo tanto, considerando que la restitución del monto recaudado se encuentra presente en el caso de los pagos a cuenta, en el Sistema

Tributario Peruano, los pagos a cuenta no son tributos, en ese mismo, sentido en la doctrina nacional se indica en lo que atañe a los pagos a cuenta “... es asimilable al empréstito forzoso, porque, al igual que éste, es un vínculo personal, pecuniario, nacido de la voluntad unilateral del Estado, a través de un mandato legal y exigible coactivamente, con la obligación de devolver en un plazo determinado...”.

A efectos de determinar si los anticipos pueden ser calificados como empréstitos forzosos o no, resulta conveniente entender los alcances de este concepto.

En relación al concepto de empréstitos forzosos, Ferreriro Lapatza (2010) sostiene que "(...) la expresión "empréstito público" debe referirse, dándole una igual importancia, a todos los préstamos que el Estado emite, es decir, ofrece al público en los mercados de capitales, tanto si están representados por títulos valores como por valores anotados (...)" (p. 113-114); y, agrega que:

(...) a través de un préstamo, en su sentido técnico-jurídico más preciso, es decir, a través de un contrato real, unilateral, de Derecho Público, por el que una de las partes (que puede ser un ente público o un particular) entrega a un ente público una cantidad de dinero comprometiéndose éste a reembolsar la cantidad y a pagar los intereses pactados (...) (p. 112)

Por su parte, Jarach (1983) señala, en relación a los empréstitos, que:

(...) se trata de empréstitos que por fuerza de ley deben suscribir los habitantes de un determinado país cuando se encuentren en las situaciones de hecho que la propia ley define. Esta dispone también con carácter obligatorio el tipo de interés que se pagará a los tenedores de títulos y la forma de amortización y reembolso del capital. El interés periódico puede faltar completamente o ser inferior al tipo vigente en la plaza al tiempo de la emisión. Es muy probable que esto acontezca, pues el Estado recurre al empréstito forzoso precisamente en la prevención que una emisión de un empréstito voluntario en las condiciones del mercado no tendría éxito.

También influye en la decisión del gobierno de acudir a este empréstito en lugar de otra alternativa, por ejemplo, de establecer un impuesto extraordinario al patrimonio, la 
suposición que la medida puede más fácilmente lograr el consentimiento de la población y de sus representantes parlamentarios (...) (p. 249)

De otro lado, Giuliani Fonrouge (1993) indica que:

(...) el empréstito público tiene el carácter de una obligación unilateral de derecho público, derivada de la soberanía (...)” (p. 236); y, asimismo, agrega que en virtud de tal obligación “(...) el Estado prestatario asume la obligación de restituir el capital recibido y de pagar un interés (...) (p. 1117).

No obstante ello, el mismo autor expresa que:

(...) no hay uniformidad en cuanto a la esencia de tal obligación de carácter unilateral y deriva de la soberanía, en tanto que para otros es de tipo bilateral y contractual, aunque estos tampoco coinciden acerca de si el contrato es de derecho público o de derecho privado; y ello, sin hablar de algunas posiciones intermedias (...) (p. 1117).

De todo lo antes expuesto se desprende que los empréstitos forzosos son aquellos préstamos de capital que las personas, naturales o jurídicas, de derecho privado o de derecho público, se encuentran obligadas a efectuar al Estado o a un ente estatal, en virtud de una ley que establece tal obligación, a cambio de lo cual aquel les pagará una determinada cantidad de intereses durante el plazo de vigencia de tal préstamo, en el que se amortizará el capital y se pagarán dichos intereses. Téngase presente que la existencia o no de intereses, no afecta la naturaleza de los empréstitos forzosos.

Como podemos apreciar, la diferencia existente entre los empréstitos forzosos y los tributos, es que en los primeros el Estado asume las obligaciones referentes al pago de intereses y de amortización de la deuda hasta la extinción de la misma a su vencimiento, mientras que en los segundos el Estado no asume tales obligaciones, tal como lo sostiene Jarach (1983).

Esta posición es compartida por Lázaro Orihuela (2016), que señala que las características que rigen y diferencian a los empréstitos forzosos son: a) la obligación de entregar (compulsivamente) sumas de dinero al Estado; b) la asunción de una obligación por parte del Estado de restituir el capital recibido; y, c) el pago de un interés por dicho monto. (p. 284)

De lo expuesto, discrepo con la posición doctrinaria que califica a los anticipos como obligaciones legales no tributarias que se asemejan a los empréstitos forzosos. 
Si se analiza por que se origina tal posición doctrinaria, puedo interpretar que proviene de una interpretación limitada de normas como el artículo 1 del CT, según las cuales "La obligación tributaria, que es de derecho público, es el vínculo entre el acreedor y el deudor tributario, establecido por ley, que tiene por objeto el cumplimiento de la prestación tributaria, siendo exigible coactivamente."

Como se puede apreciar la definición vertida en el artículo 1 del CT sólo contempla que la obligación tributaria constituye una relación acreedor - deudor que tiene por objeto que se cumpla con la conducta de dar o entregar, al acreedor, los recursos o fondos que corresponden al tributo; sin embargo, entender que la obligación tributaria sólo se reduce a ello o que es el único tipo de obligación tributaria que puede existir, es limitarla a uno de sus aspectos, que aunque sea el principal, no es el único.

En efecto, Ferreiro Lapatza (2010) sostiene que:

Aceptada, así, la definición del tributo como obligación parece necesario aceptar también que el Derecho tributario, como parte del ordenamiento, tiene como fin esencial regular esta obligación; y podemos comprender por qué la LGT 1963 y la doctrina elaborada en torno a ella -es decir, nuestro Derecho tributario tradicional-reservó para ella, para la obligación que nace de la realización del hecho imponible (cfr. art. 28 LGT 1963), el nombre e obligación tributaria. Pues aunque el Derecho tributario regula y establece otros vínculos y relaciones -también obligatorias y también tributarias en cuanto establecidas y reguladas por normas tributarias - la obligación que nace del hecho imponible es la obligación tributaria por antonomasia porque ella es -jurídicamente hablando-el tributo y, en función y por causa de ella, se establecen y regulan en las normas tributarias el resto de las obligaciones.

Obviamente, como acabamos de señalar, el Derecho tributario no puede reducirse a la regulación de la obligación tributaria entendida como la obligación de dar una suma de dinero a título de tributo por parte de quien haya realizado el hecho previsto por la Ley que la hace nacer, es decir, el hecho imponible.

Nadie pretendió jamás defender este minimalismo jurídico tan absurdo como de imposible realización en todo el ámbito del Ordenamiento jurídico y en relación con cualquier institución; nadie ha pretendido nunca, p. ej., regular el arrendamiento disciplinando sólo la obligación de pago del arrendatario sin atender, también p. ej., a la obligación de conservar en uso el bien arrendado.

El Derecho tributario no disciplina sólo la obligación de pago en que el tributo consiste. Regula otras muchas situaciones, vínculos y relaciones encaminadas todas ellas en su 
normativa y dentro de un orden constitucional democrático como el nuestro a dos fines esenciales: la efectiva aplicación de los tributos conforme al principio constitucional de capacidad y el sostenimiento del poder -también del poder tributario- y de su ejercicio a la Ley y al Derecho.

Pero, ciertamente, en el inicio de la construcción dogmática de nuestro actual Derecho tributario, la doctrina centró en demasía sus esfuerzos en el análisis de la obligación tributaria: nacimiento, sujetos, contenido y extinción. Y descuidó en igual medida tanto el estudio de los otros vínculos y relaciones de carácter sustantivo regulados por las normas tributarias como el estudio del procedimiento a través del cual han de aplicarse las normas de Derecho tributario material o sustantivo." (p.172-173)

Ahora bien, en el CT adicionalmente al artículo 1, existen otras disposiciones en las cuales se pueden evidenciar la existencia de otras obligaciones tributarias sustantivas, materiales y formales. A manera de ejemplo, mencionamos el caso de los intereses moratorios regulados en los artículos 33 y 34 del CT, los cuales constituyen obligaciones tributarias sustantivas de carácter accesorio y que serán desarrolladas con mayor amplitud en el literal (b) siguiente.

Por lo expuesto, resulta propicio citar a Fernández Cartagena (1989) que define a los anticipos como:

(...) obligaciones tributarias sustanciales pues han sido creados por normas de contenido tributario que, además, no se refieren a la creación de deberes instrumentales o de facilitación de la determinación tributaria sino más bien a la creación de una deuda pecuniaria a favor del Fisco (p.116).

Adicionalmente, considero que los anticipos no pueden ser considerados como empréstitos forzosos, por cuanto no poseen todas las características que la doctrina les atribuye a éstos y la causa que los origina es distinta.

\section{(b) Los "anticipos" como obligaciones legales tributarias:}

Conforme a este criterio, los "anticipos" constituyen obligaciones legales (ex lege) cuya finalidad es brindar dinero a favor de las Administraciones Tributarias, el que será destinado a los fines fiscales del Estado. El hecho que en virtud de tales obligaciones los particulares deban desprenderse de parte de sus recursos, para proveer de fondos al fisco, 
implica que tal obligación no es una de carácter formal, sino que constituye una obligación legal sustantiva.

El hecho que los "anticipos" califiquen como obligaciones legales sustantivas, implica que existe un elemento adicional similar a los que contienen las obligaciones tributarias; sin embargo, ello no resulta suficiente para catalogar a los "anticipos" como obligaciones tributarias.

Otro elemento que puede ser empleado para calificar a los "anticipos" como obligaciones tributarias, es el referido a que los "anticipos" son obligaciones que son creadas por ley. Sin embargo, ¿qué leyes son las que crean los “anticipos”?

Los "anticipos" son creados, contenidos y regulados por leyes de carácter tributario.

Los pagos a cuenta son obligaciones tributarias sustanciales pues han sido creados por normas de contenido tributario que, además, no se refieren a la creación de deberes instrumentales o de facilitación de la determinación tributaria sino más bien a la creación de una deuda pecuniaria a favor del Fisco. (Fernández Cartagena, 1989, p. 116)

En relación a la naturaleza jurídica de los anticipos, Villegas (1998) sostiene que:

(...) los anticipos constituyen obligaciones distintas, con su propia individualidad, su propia fecha de vencimiento, su propia posibilidad de devengar intereses resarcitorios y generar actualización monetaria, así como su propia posibilidad de ser pretendido su cobro mediante ejecución fiscal (...) tal individualidad no es absoluta, dado que el anticipo debe mantener sujeción a un determinado impuesto (...) el pago que se realiza como anticipo está siempre subordinado a la liquidación final a realizarse con la declaración jurada anual (...). ${ }^{17}$ (p. 30)

Por su parte, Luque (1989) indica que los anticipos:

(...) constituyen obligaciones tributarias sustantivas independientes de la obligación del impuesto definitivo (...), que tienen como causa o razón económica, la necesidad de anticipar al Fisco los ingresos que presumiblemente debe obtener al final del ejercicio por concepto del impuesto definitivo. (p. 122)

Y, además agrega que:

17 Sobre el particular, en las Resoluciones del Tribunal Fiscal No 12505-3-2014, 00942-4-2014, 120609-2013, 19170-1-2011 y 04435-4-2003, dicho órgano colegiado se ha pronunciado en el mismo sentido al indicar que el pago a cuenta constituye una obligación tributaria distinta pero vinculada a la obligación tributaria sustantiva, que se devenga solamente al final del período. 
Los pagos a cuenta son obligaciones tributarias independientes porque la ley los establece en base a presupuestos de hecho independientes que tienen sus propios elementos constitutivos. Esto no significa que el legislador, al momento de configurar la hipótesis de afectación de los mismos, pueda hacerlo en forma arbitraria. Siendo obligaciones tributarias, deberá tomar en cuenta las limitaciones constitucionales establecidas en relación a cualquier obligación de esta naturaleza. (p. 122)

Siguiendo esta línea, el Tribunal Fiscal en los considerandos de la RTF Nº 02600-5-2003 sostiene que:

en la Resolución del Tribunal Fiscal No 796-2-2001 de 28 de junio de 2001 se ha señalado que los anticipos o pagos a cuenta, "son simples anticipos del impuesto que es determinado recién al final del ejercicio" y autores como Juan Roque García Mullin, han señalado que "los anticipos o pagos a cuenta constituyen obligaciones creadas por la ley en forma paralela a la obligación tributaria sustantiva (que se devenga solamente al final del período)...”. En este orden de ideas, en este caso, dada la estrecha vinculación de la obligación de efectuar pagos a cuenta o anticipos del Impuesto a la Renta, con la obligación tributaria sustantiva de dicho tributo (que es de periodicidad anual y se generará al cierre del ejercicio), para efecto de la aplicación del beneficio de suspensión de fiscalización que regulaba el derogado artículo $81^{\circ}$ del Código Tributario, los pagos a cuenta o anticipos del Impuesto a la Renta debían regirse por las mismas reglas aplicables al Impuesto a la renta, como tributo de liquidación anual.

Esa misma RTF No 02600-5-2003 fijó como jurisprudencia de observancia obligatoria el siguiente criterio:

Para la suspensión de la fiscalización regulada por el artículo $81^{\circ}$ del Texto Único Ordenado del Código Tributario aprobado por Decreto Supremo No 135-99-EF, los pagos a cuenta del Impuesto a la Renta se rigen por las reglas aplicables para los tributos de periodicidad anual.

Si bien en la RTF $N^{\circ}$ 02600-5-2003 no hace expresa mención a que los anticipos constituyen obligaciones tributarias, al someter a los "anticipos" del IR a las reglas aplicables para los tributos de periodicidad anual, implícitamente se les otorga la calidad de obligaciones tributarias.

De igual forma, el Tribunal Fiscal en diversas resoluciones (RTF No 04435-42003, 03912-5-2004, 04841-5-2004, 03171-5-2004, 10713-3-2007, 05359-3-2017, 02486-4-2017, 06507-1-2003, 7927-4-2008, 9581-1-2014 y 11116-4-2015) califican a los "anticipos" como obligaciones tributarias: 
los pagos a cuenta constituyen obligaciones tributarias puesto que son prestaciones pecuniarias que el deudor se encuentra obligado a cumplir por orden de la ley, teniendo el acreedor tributario el derecho a exigir coactivamente tales prestaciones relacionadas con un tributo, es este caso el impuesto a la renta, contando con un hecho generador y base de cálculo específicos, como es el ingreso neto de tercera categoría del mes. (RTF $\mathrm{N}^{\circ}$ 10713-3-2007)

Recientemente, en la RTF № 05359-3-2017, que constituye precedente de observancia obligatoria, el Tribunal Fiscal ha reiterado su posición referida a reconocer la naturaleza tributaria de los anticipos al señalar lo siguiente:

(...) los anticipos o pagos a cuenta del Impuesto a la Renta constituyen obligaciones tributarias distintas pero vinculadas con la obligación tributaria sustantiva que se devengará al final del período, siendo independientes de su determinación anual, pues su cumplimiento debe ser anterior y se produce aun cuando finalmente en dicha determinación anual el tributo a pagar sea menor o incluso no exista renta imponible, lo que se evidencia por el hecho que su pago fuera de los plazos establecidos genera intereses moratorios de conformidad con lo establecido por los artículos $33^{\circ}$ y $34^{\circ}$ del Código Tributario, desde la fecha de su vencimiento y no desde la fecha de la obligación principal (...)

Ferreiro Lapatza (2010) al desarrollar la teoría de la "Pluralidad de obligaciones tributarias", sostiene que:

debe denominarse (como se hace ahora en nuestro Ordenamiento) obligación tributaria principal a la obligación que surge de la realización del hecho imponible a cargo, precisamente, de quien lo realiza; a cargo, según la terminología de la LGT, del contribuyente. Pues ella tiene por objeto, precisamente, la prestación debida como tributo. (p. 178)

Junto a ella se sitúan otras obligaciones que tienen también como objeto, total o parcialmente, la misma prestación: la obligación a cargo del contribuyente de realizar pagos a cuenta de la obligación que nace con la realización del hecho imponible (la obligación, p. ej.; de realizar pagos fraccionados por profesionales o empresarios individuales a cuenta de la obligación que, en su caso, surja para ellos con el vencimiento de cada periodo impositivo); (...) (p. 178)

(...) las obligaciones de pago a cuenta no pueden concebirse si no en íntima relación con la obligación tributaria principal $<<$ a cuenta de la cual $\gg>$ se pagan. (p. 179) 
Esta íntima relación con la obligación tributaria principal deriva de que todas ellas satisfacen el mismo y único interés del acreedor: el cobro del tributo debido. Ello supone que, satisfecho este interés, realizado el pago de cualquiera de ellas, debieran considerarse extinguidas en la misma proporción o grado la obligación principal y extinguida la obligación principal debería extinguirse en todo caso la llamada obligación a cuenta o la del responsable. A este tipo de obligaciones así relacionadas con la principal, a este tipo especial de accesoriedad se refiere nuestra más reciente y rigurosa doctrina de Derecho civil con el término $<$ subsidiariedad $\gg$. La obligación subsidiaria no tiene por qué recaer sobre el mismo sujeto, pero se refiere al mismo objeto o prestación: realizada ésta se extingue la obligación principal o subsidiaria no cumplida. (p. 179)

De todo lo antes expuesto, resulta claro que de forma coherente tanto la doctrina como la jurisprudencia del Tribunal Fiscal, mayoritariamente, se inclinan a considerar que los "anticipos" califican como obligaciones de carácter tributario sustantivas y subsidiarias. Como lo desarrollaremos en el próximo tema del presente trabajo, tal definición de los “anticipos” como obligaciones tributarias genera consecuencias relevantes.

\section{(c)Los límites a la potestad tributaria aplicados a los "anticipos":}

Al haberse concluido en el acápite anterior que los anticipos constituyen obligaciones legales tributarias, corresponde determinar si resultan aplicables a los mismos los principios previstos en el artículo 74 de la Constitución Política del Perú, que regulan el ejercicio de la potestad tributaria del Estado.

En relación a ello, Landa Arroyo (2006) sostiene que “(...) el artículo 74 de la Constitución ha recogido, enunciativamente, principios que tienen una relación directa con la potestad tributaria del Estado, entendidos como directrices que proveen criterios para el ejercicio discrecional de la potestad tributaria del Estado (...)”. (p. 40)

Por su parte, Danos Ordoñez (2006) refiere que:

(...) La Constitución consagra un conjunto de principios rectores de la tributación, entre los que se encuentra el de no confiscatoriedad, que constituyen pautas o reglas de orden formal y material a las que deben sujetarse los poderes públicos en el ejercicio del poder tributario o en la aplicación de los tributos (...). (p. 136) 
Estos principios, que limitan el ejercicio de la potestad tributaria del Estado, en opinión de Rodríguez Bereij citado por Danos (2006), cumplen una doble función en el ordenamiento jurídico:

(...) Por una parte cumplen una función positiva que consiste en la influencia que éstos ejercen debido a su calidad de fuentes e informadores del ordenamiento jurídico en el contenido de las normas legales que apruebe el legislador, de las decisiones jurisprudenciales que adopten los jueces y como referencia obligada para la interpretación de la legislación ordinaria, pero por otra cumplen también una función negativa excluyendo del ordenamiento jurídico a los valores contrapuestos y a las normas legales que descansan sobre éstos valores vulnerando los citados principios (...) (p. 136)

En torno a los principios constitucionales tributarios, consagrados en el artículo $74^{\circ}$ de la Constitución, que regulan el régimen tributario peruano, en el considerando 3 de la sentencia recaída en el Expediente $\mathrm{N}^{\mathrm{o}} 3303-2003-\mathrm{AA} / \mathrm{TC}$, el Tribunal Constitucional ha manifestado que " (...) constituyen límites de observancia obligatoria para quienes ejercen el poder tributario de acuerdo a la Constitución (...)"

Asimismo, en la sentencia recaída en el Expediente $\mathrm{N}^{\circ}$ 06089-2006-PA/TC (Fund. 49), el Tribunal Constitucional expresó que:

La potestad tributaria del Estado debe ejercerse, antes que en función de la ley, en función de la Constitución --principio de supremacía constitucional (artículo 51)-- y de los principios que ella consagra e informa. Dichos principios, por otra parte, constituyen una garantía para los contribuyentes, en tanto establecen que no se puede ejercer la potestad tributaria contra la Constitución ni de modo absolutamente discrecional o arbitrario.

Ahora bien, respecto a la finalidad de estos principios, en el considerando 8 de la sentencia recaída en el Expediente Nº 0042-2004-AI/TC, el Tribunal Constitucional indicó que:

(...) cuando la Constitución establece dichos principios [los principios constitucionales tributarios] como límites informadores del ejercicio de la potestad tributaria ha querido proteger a las personas frente a la arbitrariedad en la que puede incurrir el Estado cuando el poder tributario se realiza fuera del marco constitucional establecido. Por eso mismo, el último párrafo del artículo $74^{\circ}$ de la Ley Fundamental establece que "no surten efecto las normas tributarias dictadas en violación de lo que establece el presente artículo" (...). 
De ello se desprende que los principios constitucionales tributarios recogidos en el artículo 74 de la Constitución Política del Perú son los límites que debe observar el Estado en el ejercicio de su potestad tributaria para la creación, modificación o extinción de tributos, a fin de evitar que el mismo sea calificado como arbitrario.

De otro lado, en el considerando 8 de la sentencia dictada en el Expediente $\mathrm{N}^{\circ}$ 033-2004-AI/TC, el Tribunal Constitucional estableció que:

Este Tribunal considera necesario precisar, más allá de que el tema abordado en esta sección constituye cuestión pacífica, que no existe argumentación valedera que permita sostener que los límites de la potestad tributaria previstos constitucionalmente no son de aplicación a las obligaciones legales derivadas de una obligación tributaria en tanto ellas se estructuran y aplican teniendo en cuenta el tributo al cual se encuentran ligadas; en este caso, al tratarse de un sistema de pagos anticipados que se ejecuta dentro de la estructura del Impuesto a la Renta -como coinciden demandantes y demandados-, es pertinente que el análisis de la norma cuestionada se someta a los límites a la potestad tributaria previstos en la Carta Magna, y sólo desde allí, verificar si nos encontramos ante una norma inconstitucional.

En atención a lo manifestado en el presente trabajo, respecto a la naturaleza tributaria de los "anticipos"; y a que como manifiesta el TC respecto de los "anticipos" que se ejecutan "dentro de la estructura del impuesto a la renta (...)”, resulta pertinente que el análisis de los mismos se someta a los límites de la potestad tributaria previstos en el artículo 74 de la Constitución Política del Perú.

Como hemos visto, el artículo 74 de la Constitución contiene los principios constitucionales que rigen el ejercicio de la potestad tributaria del Estado, los cuales constituyen verdaderos límites al mismo. El segundo párrafo del artículo 74 de la Constitución dispone que la potestad tributaria del Estado debe ser ejercida respetando los siguientes principios:

(a) Reserva de ley.

(b) Igualdad.

(c) Respecto de los derechos fundamentales de la persona.

(d) Ningún tributo puede tener carácter confiscatorio. 
Para efectos del presente trabajo, nos interesa tratar los conceptos detallados en los literales (b) y (d).

\section{- Principio de Igualdad:}

En relación al principio de igualdad, Landa Arroyo (2006) sostiene que:

(...) este principio en materia tributaria directa debe ser entendido en el sentido que las situaciones económicas iguales deben ser tratadas de la misma manera y, a la inversa, situaciones económicamente disímiles, deben recibir un trato diferenciado. En tal sentido, el principio de igualdad no prohíbe cualquier desigualdad, sino aquella que deviene en discriminatoria por carecer de razonabilidad y de justificación objetiva (...). (p. 44)

Sobre el particular, en las sentencias recaídas en el Expediente $\mathrm{N}^{\circ}$ 2727-2002-AA/TC (Fund. 4) y 001-2004-AI/TC y 002-2004-AI/TC (Fund. 50), el Tribunal Constitucional ha manifestado que:

(...) la potestad tributaria del Estado (...) se encuentra directamente conectada con el derecho de igualdad en materia tributaria o, lo que es lo mismo, con el principio de capacidad contributiva, según el cual, el reparto de los tributos ha de realizarse de forma tal que se trate igual a los iguales y desigual a los desiguales, por lo que las cargas tributarias han de recaer, en principio, donde exista riqueza que pueda ser gravada, lo que evidentemente implica que se tenga en consideración la capacidad personal o patrimonial de los contribuyentes (...).

En ese orden de ideas, cuando la Constitución en el artículo 74 hace mención del principio de igualdad, lo hace entendiendo que para efectos tributarios se debe tratar igual a los iguales y de forma distinta a los desiguales. Ello debe ser entendido bajo los conceptos de igualdad horizontal e igualdad vertical, según lo expuesto por el Tribunal Constitucional en la sentencia recaída en el Expediente № 4014-2005-AA/TC.

En efecto, en el considerando 7 de la citada sentencia, el Tribunal Constitucional ha establecido lo siguiente:

(...) el principio de igualdad tributaria, sea en el plano horizontal o vertical, va de la mano con la capacidad contributiva, determinando, por un lado, que a igual manifestación de riqueza se generalice la obligación de pago; y, por el otro, que dicha obligación sea proporcional a la capacidad contributiva del obligado (...). 
Por su parte, en el punto $\S 1$ del rubro B de la parte VIII de la sentencia recaída en el Expediente $\mathrm{N}^{\mathrm{o}}$ 00053-2004-PI/TC, el Tribunal Constitucional ha agregado que la vertiente vertical del principio de igualdad se encuentra unificada al principio de capacidad contributiva, debido a que “(...) constituye la base para la determinación de la cantidad individual con que cada sujeto puede/debe en mayor o menor medida, contribuir a financiar el gasto público (...)"18.

En tal sentido, la igualdad horizontal implica que a igual capacidad contributiva, igual carga tributaria; $y$, la igualdad vertical implica que a distinta capacidad contributiva, corresponde distinta carga tributaria.

Como se puede apreciar el principio de igualdad contenido en el artículo 74 de la Constitución, se encuentra estrechamente ligado al principio constitucional implícito de capacidad contributiva.

Dado que los "anticipos" del IR constituyen obligaciones tributarias, como hemos mencionado en el presente trabajo, los mismos deben ser determinados tomando como referencia una base presunta que evidencia cierta capacidad contributiva.

En nuestro país, el artículo 85 de la LIR emplea el ingreso neto devengado en cada mes como elemento representativo de capacidad contributiva, para efectos de determinar el monto de los anticipos del IR.

Sin embargo, el empleo, en los "anticipos" del IR, de una base presuntiva de capacidad económica (ingreso neto) no resulta suficiente para cumplir con el principio de igualdad y con la capacidad contributiva, puesto que, adicionalmente, se requiere que exista proporcionalidad entre el "anticipo" (obligación tributaria provisional) y el impuesto (obligación tributaria definitiva).

Tal como lo manifestamos en el Capítulo III del presente trabajo, los anticipos constituyen estimaciones razonables que, en condiciones normales, al final del ejercicio deben ser cercanas al monto del IR anual. Por ello, García Mullin (1978) detalla que

\footnotetext{
18 Es más, en la nota 5 de la misma sentencia, el Tribunal Constitucional, cita a M. Corti, quien sostiene que “(...) La igualdad en el plano vertical, se identifica con la proporcionalidad y ésta con la capacidad contributiva, alcanzando también la redistribución o igualdad de hecho”.

M. Corti, Arístides Horacio: De los principios de justicia que gobiernan la tributación (igualdad y equidad). En: Estudios de Derecho Constitucional Tributario. Homenaje a Juan Carlos Luqui. Ed. Depalma. Bs. As. 1994. Pág. 281. Citado por el Tribunal Constitucional.
} 
los anticipos a lo largo de un año equivaldrán al impuesto generado el año anterior. Como esa cifra se puede obtener en los primeros meses, a lo largo del año puede irse logrando una anticipación razonable, suponiendo (...) que la actividad económica generadora de renta del contribuyente es aproximadamente igual en ambos años (...). (p. 173)

Atendiendo a ello, en los anticipos existen estimaciones que se elaboran en función al IR del ejercicio anterior y que reflejan la capacidad contributiva. Fernández Cartagena (1989) sostiene que en "cuanto no exista capacidad contributiva que convalide el título jurídico del Estado para exigir los pagos a cuenta, estas obligaciones perderán virtualidad jurídica por carecer de causa y, por tanto, no podrán seguir siendo exigibles por el Estado.” (p. 119)
Ahora bien, en:
el caso de los anticipos o pagos a cuenta del Impuesto a la Renta, el respeto al principio de capacidad económica se manifiesta en un doble sentido: (i) la propia cuantía del pago a cuenta ha de calcularse sobre la base de elementos representativos de capacidad económica (rentas netas, rentas brutas, ingresos) y, (ii) la proporcionalidad que ha de guardar la cuantía del pago a cuenta con el monto del Impuesto a la Renta anual que en definitiva tendrá que pagar el contribuyente. (Exp. N $^{\circ} 0033-2004-\mathrm{AI} / \mathrm{TC}$, fund. 13)

Retomando el ejemplo numérico planteado en el Capítulo I del presente trabajo, se evidenció que de aplicar la interpretación planteada por SUNAT, respecto de la determinación de los anticipos de tercera categoría del IR se obligaría a las empresas operadoras de casinos y/o salas de máquinas tragamonedas a entregar al fisco, en un año, anticipos equivalentes al IR que debería pagarse en los próximos diez (10) años.

Ello evidencia que no existe proporcionalidad entre los anticipos y el IR que se genera al final del ejercicio.

En consecuencia, la interpretación planteada por SUNAT, referida a que la totalidad de las apuestas (Coin In) recibidas por los operadores de casinos y/o salas de máquinas tragamonedas constituyen la base de cálculo de los anticipos de tercera categoría del IR, transgrede flagrantemente el principio de igualdad contenido en el artículo 74 de la Constitución Política de 1993.

\section{- Ningún tributo puede tener carácter confiscatorio:}


En relación al principio de no confiscatoriedad, Landa Arroyo (2006) sostiene que:

(...) el principio de interdicción de la confiscatoriedad está estrechamente vinculado con el principio de capacidad contributiva y el de respeto de los derechos fundamentales; específicamente con el derecho fundamental a la propiedad que la Constitución reconoce (artículo 2-16 y 70) (...)”; y, que “(...) dicho mandato no es sino la concretización autónoma del principio de proporcionalidad inherente a todo Estado constitucional democrático, en cuanto prohibición o interdicción de la excesividad de la imposición (...).(p. 46)

Sobre el particular, en el considerando 4 de la sentencia recaída en el Expediente $N^{\circ} 2727$ 2002-AA/TC, el Tribunal Constitucional estableció que el principio de no confiscatoriedad:

(...) informa y limita el ejercicio de la potestad tributaria estatal y, como tal, constituye un mecanismo de defensa de ciertos derechos constitucionales, empezando, desde luego, por el derecho de propiedad, ya que evita que la ley tributaria pueda afectar irrazonable y desproporcionadamente la esfera patrimonial de las personas. Asimismo, se encuentra directamente conectado con el derecho de igualdad en materia tributaria o, lo que es lo mismo, con el principio de capacidad contributiva, según el cual, el reparto de los tributos ha de realizarse de forma tal que se trate igual a los iguales y desigual a los desiguales, por lo que las cargas tributarias han de recaer, en principio, donde exista riqueza que pueda ser gravada, lo que evidentemente implica que se tenga en consideración la capacidad personal o patrimonial de los contribuyentes.

En esa misma sentencia del TC se establece que el principio de no confiscatoriedad de los tributos "asegura que ciertas instituciones que conforman nuestra Constitución económica, como el pluralismo económico, la propiedad o la empresa, no resulten suprimidas o vaciadas de contenido cuando el Estado ejerza su potestad tributaria.”

Como consecuencia de la omisión de los principios constitucionales, en especial el de capacidad económica, surge la confiscatoriedad de un tributo y conlleva que a un contribuyente se le prive de sus rentas, propiedades y patrimonio; vulnerándose el derecho a la propiedad e incluso al de la libre empresa.

Por esa razón, en las sentencias recaídas en el Expediente N $^{\circ}$ 2727-2002-AA/TC (Fund. 5) y 1907-2003-AA/TC (Fund. 4), el Tribunal Constitucional ha manifestado que:

(...) se transgrede el principio de no confiscatoriedad de los tributos cada vez que un tributo excede del límite que razonablemente puede admitirse como 
justificado en un régimen en el que se ha garantizado constitucionalmente el derecho subjetivo a la propiedad $\mathrm{y}$, además, ha considerado a esta como institución, como uno de los componentes básicos y esenciales de nuestro modelo de Constitución Económica (...).

De igual forma, en la sentencia recaida en el Expediente $\mathrm{N}^{\circ}$ 2302-2003-AA/TC el Tribunal Constitucional se refirió al principio de no confiscatoriedad, sosteniendo que:

Su contenido constitucionalmente protegido no puede ser precisado en términos generales y abstractos, sino que debe ser analizado y observado en cada caso, teniendo en consideración la clase de tributo y las circunstancias concretas de quienes estén obligados a sufragarlo. No obstante, teniendo en cuenta las funciones que cumple en nuestro Estado democrático de Derecho, es posible afirmar, con carácter general, que se transgrede el principio de no confiscatoriedad de los tributos cada vez que un tributo excede el límite que razonablemente se admite para no vulnerar el derecho a la propiedad.

En los casos (en) que se alegue confiscatoriedad, es necesario que la misma se encuentre plena y fehacientemente demostrada. De lo contrario, corresponderá atender este tipo de procesos en otra vía, donde si puedan actuarse otros medios de prueba y proceda la intervención de peritos independientes que certifiquen las afectaciones patrimoniales a causa de impuestos.

Recurriendo nuevamente al ejemplo numérico planteado en el Capítulo I del presente trabajo, de aplicarse el planteamiento de SUNAT según el cual la totalidad de las apuestas (coin in) efectuadas en el mes, son la base de cálculo de los anticipos de tercera categoría del IR; se evidencia que la empresa de salas de máquinas tragamonedas de tal ejemplo podría suspender los anticipos de tercera categoría a partir de mes de agosto de 2016, lo que implica que debería desembolsar hasta el anticipo de julio de 2016. Ello implica que por los desembolsos a los anticipos de tercera categoría del IR por el período comprendido entre enero a julio de 2016, se habría tenido que desembolsar un monto ascendente a S/. 122`091,666.66. Tal monto resulta ser equivalente al IR que debería pagarse en los próximos diez (10) años. ${ }^{19}$

Si se tiene en cuenta que los "anticipos" del IR constituyen obligaciones tributarias, y los mismos estarían afectando considerablemente el patrimonio de la empresa de salas de máquinas tragamonedas, materia del ejemplo numérico; no cabe duda

\footnotetext{
${ }^{19}$ Bajo la premisa que todos los ejercicios son equiparables y se obtienen resultados similares.
} 
que calificarían como confiscatorios los anticipos de tercera categoría del IR, de implementarse la interpretación planteada por SUNAT en las fiscalizaciones a diversos operadores de casinos y/o salas de máquinas tragamonedas. 


\section{CAPÍTULO IV: CONCEPTO DE INGRESO}

\subsection{EI término "Ingreso" en la Ley del Impuesto a la Renta}

En el texto de la LIR se emplean múltiples términos o conceptos de naturaleza u origen contable, tal es el caso de conceptos como "activo", "pasivo", "costo computable", “amortización”, “depreciación”, “inventarios”, “devengado”, “ingresos”, etc.; sin embargo, en la LIR no existe una definición de los mismos.

Para efectos del presente trabajo, guarda especial relevancia el término "ingreso", el mismo que ha sido ampliamente desarrollado por la ciencia contable. En efecto, Villanueva (2004) sostiene que:

Si admitimos que el concepto de renta es, en el caso de las empresas, un concepto contable y que dicho concepto es un resultado obtenido de la comparación de ingresos y costos, resulta imprescindible comprender el concepto de ingreso desde el punto de vista de las ciencias contables. (p. 6)

En efecto, el término "ingreso" es empleado con gran frecuencia en las disposiciones de la LIR. A manera de ejemplo, detallamos algunos casos:

(a) El literal a) del artículo 1 de la LIR cuando define las rentas gravadas con tal impuesto dispone que la fuente debe generar "ingresos" periódicos.

(b) El literal c) del artículo 1 de la LIR, cuando establece que se encuentran afectos al IR "Otros ingresos que provengan de terceros, establecidos por esta Ley."

(c) El artículo 3 de la LIR que define que debe entenderse por "ingresos provenientes de terceros".

(d) Los artículos 12 y 48 de la LIR, referidos a la presunción de rentas netas obtenidas por contribuyentes no domiciliados en el país que desarrollan actividades parte en el país y parte en el extranjero y que son iguales a los importes que resulten de aplicar sobre los ingresos brutos los porcentajes fijados en el artículo 48 de la LIR.

(e) El segundo párrafo del artículo 18 de la LIR, cuando detalla los ingresos inafectos al IR. 
(f) En el numeral i) del literal b) del artículo 19 de la LIR, cuando se regula lo que es la distribución indirecta de rentas entre sus asociados.

(g) El literal i) del artículo 19 de la LIR, al establecer que no se encuentran comprendidos en tal exoneración los intereses que constituyan ingresos que constituyan rentas de tercera categoría.

(h) El literal j) del artículo 19 de la LIR, cuando califica como rentas exoneradas a los ingresos brutos que perciben representaciones deportivas nacionales de países extranjeros por sus actuaciones en el país.

(i) El primer y segundo párrafos del artículo 20 de la LIR, que califican como renta bruta tanto (i) a los ingresos afectos al impuesto que se obtenga en el ejercicio gravable, (ii) como los ingresos provenientes de la enajenación de bienes.

(j) El artículo 85 de la LIR, en el cual se establece que para la determinación de los pagos a cuenta de tercera categoría, la base de cálculo se encuentra constituida por los ingresos netos obtenidos en el mes.

Cabe especial mención el caso específico de los anticipos de tercera categoría del IR a que alude el artículo 85 de la LIR, en el cual se dispone que deben considerarse como base de cálculo de tales anticipos del IR, los ingresos netos devengados durante el período mensual. Esa misma norma establece que califican como "ingresos netos" "el total de los ingresos gravables de la tercera categoría, devengados en cada mes, menos las devoluciones, bonificaciones, descuentos y demás conceptos de naturaleza similar que respondan a la costumbre de la plaza."

Por otro lado, el numeral 3 del artículo 54 del RLIR define a los "ingresos netos" que sirven de base de cálculo de los anticipos de la tercera categoría como el:

Total de ingresos gravable de la tercera categoría, devengados en cada mes, menos las devoluciones, bonificaciones, descuentos y demás conceptos de naturaleza similar que respondan a la costumbre de la plaza. Se excluye de dicho concepto al saldo de la cuenta "Resultados por Exposición a la Inflación - REI.

Las disposiciones del IR contienen una definición del término "ingresos netos"; sin embargo, ello no resulta satisfactorio, ya que nos remite al concepto de "ingreso" y éste no se encuentra definido en las disposiciones del IR. 
Nos llama la atención que tal cuerpo legal no contenga una definición del término “ingresos", generándose una omisión que es de necesidad definir. En efecto, el término “ingreso" existente en la LIR es un concepto sin contenido, es decir, un concepto vacío; ya que no existe en tal cuerpo normativo una definición del mismo. Ante ello, no cabe duda que nos encontramos ante una laguna de la ley. Sobre el particular, Lara (1997) entiende que "cuando se habla de lagunas de la ley se esté hablando de ausencia de norma legislativa." (p.95)

Por ello, tanto SUNAT (Carta No 30-2011-SUNAT/2B00000, Informes N No 0032008-SUNAT/2B0000, 85-2009-SUNAT/2B0000, 232-2009-SUNAT/2B0000, 9-2010SUNAT/2B0000，124-2010-SUNAT/2B0000，184-2013-SUNAT/4B0000， 188-2015SUNAT/5D0000, 062-2015-SUNAT/5D0000, 002-2017-SUNAT/5D0000, etc.) como el Tribunal Fiscal (RTF No 15502-10-2011, 10577-8-2010, 10813-3-2010, etc.) han buscado cubrir tal omisión remitiéndose expresamente a las disposiciones contables, tales como el Marco Conceptual para la Preparación y Presentación de los Estados Financieros (MC), como la Norma Internacional de Contabilidad No 18 (NIC 18); sosteniendo que "ante la ausencia de una definición en la legislación tributaria es válido acudir a las normas contables, máxime cuando se trata de conceptos que provienen de la contabilidad(...)." (León Huayanca, 2014, p. 192)

Durán y Mejia (2011) sostienen que de los pronunciamientos efectuados por SUNAT, al amparo del artículo 93 del CT, se aprecia que:

esta entidad no mantiene un patrón constante respecto al uso de las normas contables como fuente interpretativa de las normas tributarias y, lo que es más sorprendente, no tiene claro el tipo de fuente de que se trata. De hecho, se puede ver que en algunos casos la SUNAT usa las normas contables de manera directa sin señalar la razón para hacerlo, en otros lo hace refiriendo que ello se enmarca en lo señalado en la citada Norma IX del Título Preliminar del CT, e incluso hay casos en los que las normas contables no son usadas por la Administración Tributaria pese a tratarse de disposiciones tributarias con evidente raigambre contable. (p. 51)

Tal proceder nos obliga, de manera previa, a determinar si resulta correcto emplear los conceptos contables para cubrir vacíos u omisiones existentes en las disposiciones de la LIR. 


\subsubsection{Interacción entre normas contables y la Ley General de Sociedades y disposiciones del Impuesto a la Renta}

En primer término, el artículo 223 de la Ley General de Sociedades (LGS) estableció que "Los estados financieros se preparan y presentan de conformidad con las disposiciones legales sobre la materia y con principios de contabilidad generalmente aceptados en el país." De igual forma, la Cuarta Disposición Final de la LGS brindó una definición de lo que debe entenderse por "Estado Financiero", estableciendo que dentro de ese término sólo se encuentran comprendidos el balance general y el estado de ganancias y pérdidas o también denominado estado de resultados.

De lo dispuesto por la LGS se desprende que los resultados que obtengan las sociedades deben verse reflejados en los estados financieros (balance y estado de resultados); debiendo elaborar tales estados financieros en base a las disposiciones legales vigentes y los principios de contabilidad generalmente aceptados en el país.

Mediante la Resolución $N^{o}$ 013-98-EF/93.01 el Consejo Normativo de Contabilidad (CNC) precisó que los "Principios de Contabilidad Generalmente Aceptados" a que hace referencia el artículo 223 de la LGS, se encuentran referidos, substancialmente, a las NICs oficializadas mediante Resoluciones del indicado CNC y las normas establecidas por Organismos de Supervisión y Control para las entidades de su área siempre que se encuentren dentro del Marco Teórico en que se apoyan las NICs.

Una norma de rango inferior a la Ley e incluso al Decreto Supremo, precisó lo establecido en el artículo 223 de la LGS, del cual se evidencia que para poder medir y determinar los resultados obtenidos por una sociedad, se deben emplear las normas contables y los principios de contabilidad generalmente aceptados (NICs y las NIIFs).

Es imposible negarle relevancia a los aspectos contables como punto de partida sobre el cual se desarrollan los aspectos tributarios. En Perú las disposiciones del IR se remiten al resultado contable al que se le efectúan ajustes (adiciones y deducciones), luego de lo cual se obtiene el resultado tributario.

A este respecto, León Huayanca (2014) manifiesta que:

la base imponible en el Impuesto a la Renta aplicable a las actividades empresariales, debe interpretarse que parte del resultado contable (ganancia o pérdida) que fluye de los Estados Financieros de un determinado período como una herramienta, para llegar a un resultado tributario (renta neta o pérdida tributaria) luego de someter a los ingresos y 
gastos que conforman el resultado contable las reglas establecidas en la Ley del Impuesto a la Renta (...) (p. 193)

Lo antes indicado, se ratifica con lo dispuesto por el primer párrafo del artículo 33 del RLIR, según el cual:

La contabilización de operaciones bajo principios de contabilidad generalmente aceptados, puede determinar, por aplicación de las normas contenidas en la Ley, diferencias temporales y permanentes en la determinación de la renta neta. En consecuencia, salvo que la Ley o el Reglamento condicionen la deducción al registro contable, la forma de contabilización de las operaciones no originará la pérdida de una deducción.

Mur Valdivia (2002) al comentar el artículo 33 del RLIR sostiene que:

Como puede advertirse, una disposición como ésta sólo tiene sentido, si el legislador tiene en mente que los resultados de las empresas se determinen bajo principios de contabilidad generalmente aceptados, y que por tanto, el Impuesto a la Renta de estos contribuyentes no puede determinarse prescindiendo en lo absoluto de tales principios. (p. 4)

De acuerdo a Luyo Acosta (2014) existe una:

Inclinación general a entrelazar el resultado contable y la base imponible del Impuesto a la Renta. Ello explicaría por qué en nuestro país nunca se cuestionó que la base imponible del impuesto a la renta se determine a partir de los resultados del ejercicio (...). La práctica de deducir esa conexión se manifiesta en el recurso indiscriminado a las normas contables para la interpretación de normas tributarias en áreas en las que no existe habilitación en el texto legal. Este proceder también se evidencia en la actuación de la Administración Tributaria y Tribunal Fiscal, quienes parecen haber adoptado una posición temerariamente laxa, conducente a asimilar casi automáticamente los contenidos contables y a darle al citado artículo $33^{\circ}$ una interpretación que, en nuestra opinión, excede su contenido prescriptivo. (p. 312)

Mur Valdivia (2002) manifiesta que:

La tendencia de acompañar a la contabilidad en la determinación de la renta imponible ya fue advertida por la propia IFA en el marco de su Congreso Internacional celebrado en Londres en el año 1975, donde los concurrentes convocados para tratar el tema de las "Relaciones entre la contabilidad fiscal y comercial" acordaron reconocer, que para determinar la renta tributaria de las empresas debe partirse del balance comercial, sin perjuicio de la existencia de normas específicas que la diferencien del balance, razón por 
la cual, ante la falta de normas tributarias específicas prevalecen los principios contables.” (p. 4-5)

Ahora bien, es necesario determinar si las normas contables pueden ser empleadas para suplir vacíos u omisiones existentes en las normas tributarias.

\subsubsection{Norma IX del Título Preliminar del CT y las normas contables}

A este respecto, la Norma IX del Título Preliminar del CT establece que:

En lo no previsto por este Código o en otras normas tributarias podrán aplicarse normas distintas a las tributarias siempre que no se les opongan ni las desnaturalicen. Supletoriamente se aplicarán los Principios del Derecho Tributario, o en su defecto, los Principios del Derecho Administrativo y los Principios Generales del Derecho.

De la Norma IX del Título Preliminar del CT, se aprecia que existe la posibilidad que las normas tributarias en su desarrollo no prevean diversos temas o los omitan, es decir, se configure una laguna en la ley. No resulta aceptable la existencia de omisiones normativas; por lo cual, se admite que en tales casos se pueda recurrir a otras normas legales distintas de las tributarias y siempre que no las contravengan o no las desnaturalicen. Incluso la disposición bajo análisis, admite la posibilidad que de no existir una norma legal que pueda suplir tal vacío, se pueda recurrir a los "Principios del Derecho Administrativo" o los "Principios Generales del Derecho".

Del texto de la Norma IX del Título Preliminar del CT se desprende que es una norma que admite el empleo de la integración analógica; entendida esta última como un mecanismo del cual se admite la posibilidad que ante una omisión en una norma legal tributaria, se pueda recurrir en primer término a otra norma legal del ordenamiento nacional distinta de la tributaria, o de no ser posible a los principios del Derecho Administrativo o los Principios Generales del Derecho para suplir tal vacío.

Cabe mencionar que la propia Norma IX del Título Preliminar del CT contiene una omisión, ya que establece que ante lo no previsto en el CT o en otras normas tributarias se puede recurrir a otras normas legales distintas de las tributarias. Sin embargo, hubiera sido deseable que el texto de la Norma IX del Título Preliminar del CT nos hubiera remitido, en primer término, a otras normas legales de carácter tributario por ser estas normas específicas de similar naturaleza que la que contendría la laguna de ley. 
Luego de ello, si se determinase que persiste la omisión (laguna de ley) se hubiera permitido la remisión a las demás normas legales distintas a las tributarias.

Ahora bien, de una interpretación de la Norma IX del Título Preliminar del CT, no cabe duda que se admite la posibilidad de efectuar una integración de la norma tributaria afectada por la laguna de ley, con otra norma legal no tributaria; con mayor razón resulta posible efectuar una integración analógica entre dos normas legales tributarias (norma legal tributaria con laguna de ley y norma legal tributaria a integrar analógicamente).

Lara (1997) sostiene que:

cuando existe norma para el caso concreto, es de aplicación la interpretación, a efecto de a través de sus recursos desentrañar el sentido y alcance de la norma. En cambio, cuando no hay norma para el caso y nos hallamos en presencia de laguna, el recurso técnico a emplear es el de la integración jurídica." (p. 93) Este mismo autor manifiesta que "la interpretación como forma de realización del Derecho, debe haber fracasado previamente, pues del texto, tal como se halla, no se puede extraer contenidos que no alberga, ni de los que si contiene, obtener la solución que hace falta, precisamente por adolecer de problemas como indefinición, imperfección o error que la convierten en defectuosa. (p. 99)

La analogía es un medio integrativo y que:

consiste en aplicar la solución dada para uno o varios casos a otro caso no normado, siempre que entre ambos existan como elementos comunes, los elementos que son característicos y decisivos en cada uno de ellos." (Lara, 1997, p. 100) "En realidad lo que con la analogía se hace, no es aplicar toda la norma (supuesto de hecho y consecuencia jurídica) sino, únicamente la decisión contenida en ella dada la similitud existente. (Lara, 1997, p. 100)

Actualmente, la doctrina en su gran mayoría admite la posibilidad de la integración analógica; pero restringida a algunos ámbitos del derecho tributario, como son el derecho tributario administrativo, formal y procesal. Posición que es asumida por el CT.

García Belsunce (1982) describe a la analogía como:

la extensión de un precepto de ley a un caso no comprendido en la misma, pero que tiene una relación de afinidad tal, que hace suponer por aplicación de un principio lógico, que a igual premisa debe corresponder igual consecuencia y que tal habría sido la voluntad del legislador. (p. 141) 
Asimismo, García Belsunce (1982) es concluyente cuando manifiesta que la:

analogía como medio de integración de la ley tributaria sustantiva y penal no es admisible, pues no se puede por vía alguna extender el campo de aplicación de la ley. Sí es admisible en el ámbito del derecho tributario formal y del derecho tributario procesal (...) (p. 161)

Villegas (1988) al desarrollar el tema de la analogía manifiesta que:

Utilizar la analogía significa aplicar a un caso concreto no previsto por la ley, una norma que rija un caso semejante". (p. 173) "Por ello se ha sostenido, con acierto, que la analogía no es una forma de interpretar la ley, sino de integrarla. (p. 173)

De igual forma, Villegas (1988) sostiene que "no pueden ser objeto de interpretación analógica las normas que determinan los hechos imponibles, pero no se opone a la analogía en otros supuestos.” (p. 174)

Ello nos lleva a analizar si las normas contables (NIC y NIIF) califican como normas legales o principios del Derecho Administrativo o Derecho General; de tal forma, que pudieran ser empleadas supletoriamente para cubrir las omisiones o vacíos existentes en las disposiciones tributarias.

Smith (1990) define a la "norma jurídica" como:

La significación lógica creada según ciertos procedimientos instituidos por una comunidad jurídica y que, como manifestación unificada de la voluntad de ésta, formalmente expresada a través de sus órganos e instancias productoras, regula la conducta humana en un tiempo y un lugar definidos prescribiendo a los individuos, frente a determinadas circunstancias condicionantes, deberes y facultades, y estableciendo una o más sanciones coactivas para el supuesto de que dichos deberes no sean cumplidos. (p. $331)$

Tal como lo define Smith en la cita transcrita en el párrafo precedente, la norma jurídica constituye una regulación de la conducta humana y que deben cumplir aspectos formales indispensables para su existencia, tales como: (a) Que provengan del órgano competente del Estado para dictarlas, (b) Se cumplan con todas las formalidades o procedimientos establecidos para su dación.

De igual forma, Rubio Correa (2011) define a la norma jurídica como "una proposición implicativa y mandatoria, destinada a regular las conductas dentro de la sociedad al margen de consideraciones éticas políticas, etcétera.” (p. 73) 
Este mismo autor sostiene que "la norma jurídica es un mandato de que a cierto supuesto debe seguir lógico jurídicamente una consecuencia, estando tal mandato respaldado por la fuerza del Estado para el caso de su eventual incumplimiento.” (p. 76)

un rango esencial de la norma jurídica (y en verdad del sistema jurídico en su conjunto), es el del respaldo de la fuerza del Estado, entendiendo por ello que el estado garantiza el cumplimiento de las normas jurídicas, en caso necesario, mediante el uso de las instituciones públicas y de la propia fuerza de su aparato. (p. 84)

"Los elementos de la norma definida desde el punto de vista lógico jurídico son tres: supuesto, consecuencia y nexo.” (p. 87) Para efectos del presente trabajo sólo resulta conveniente tratar los elementos denominados supuesto y consecuencia. "El supuesto es la hipótesis que formula el autor de la norma jurídica para que, de verificarse u ocurrir en la realidad, se desencadene lógico jurídicamente la necesidad de la consecuencia." (p. 76). "La consecuencia es el efecto que el autor de la norma jurídica atribuye, lógico jurídicamente, a la verificación del supuesto en la realidad.” (p. 91)

De lo manifestado por Rubio (2011), en las citas precedentes, considera que la consecuencia puede contener varias modalidades como son: (a) Establecimiento de un derecho, (b) Establecimiento de una obligación, (c) Establecimiento de un deber, (d) Creación de instituciones, (e) Creación de una situación jurídica, (f) Creación de una relación jurídica, (g) Suspensión, modificación o derogación de normas existentes, (h) Establecimiento de sanciones.

En el caso de las normas contables (MC, NIC y NIIF) podemos decir que se encuentra el elemento del supuesto; sin embargo, consideramos que en ellas no se encuentra el elemento de la conclusión, ya que una vez planteado el supuesto de las normas contables no llevan inmersas conclusiones, es decir, no crean obligaciones, deberes, ni sanciones que desencadenen la fuerza del Estado (coerción o coacción).

Para un mejor entendimiento, me permito brindar el siguiente ejemplo:

Supongamos que se crea una norma de protección al consumidor que establece que el adquirente de un bien puede solicitar la devolución del costo de adquisición del bien y una indemnización por los daños que se configuren; en caso, se determine que el bien es defectuoso. Para ello, es indispensable acreditar que el adquirente es diligente al momento de la instalación y posterior uso del bien al emplear el manual de instrucciones del fabricante. 
No cabe duda que la disposición creada en el ejemplo será una norma jurídica, ya que contiene el "supuesto" y la "consecuencia" y siempre que se cumplan los aspectos formales para ser calificada como norma jurídica; sin embargo, el hecho que en la misma se detalle que el adquirente debe hacer uso del manual de instrucciones del fabricante ¿otorga al manual de instrucciones el carácter de norma jurídica? Considero que la respuesta resulta evidente, tal manual de instrucciones sólo califica como una lista de procedimientos, pautas o instrucciones de buenas prácticas a seguir; pero dista mucho de ser una norma jurídica.

Navarro Faure (2007) cita lo expuesto por Esteban Marina, según el cual "las normas contables en todo el mundo, salvo en España, son simples técnicas de registro, de empleo elástico, existiendo y pudiendo aplicarse distintas reglas - principios generalmente aceptados - a un mismo hecho registrado.” (p.23)

Tal como lo hemos detallado en el numeral 4.1.1. el artículo 33 del RLIR contiene una disposición según la cual se reconoce que los contribuyentes pueden contabilizar sus operaciones de acuerdo con las normas contables (MC, NIC y NIIF); sin embargo, se establece que la forma de contabilización de las operaciones no origina la pérdida de una deducción, salvo que por disposiciones del IR (LIR o RLIR) se condicione la deducción de un concepto al registro contable.

Ello implica relativizar los efectos de las normas contables, ya que con el artículo 33 del RLIR se les reduce relevancia para efectos tributarios, al establecer que la forma de contabilización de una operación no puede perjudicar una deducción para efectos tributarios. Adicionalmente, la norma contable referida a la contabilización de una deducción sólo tendrá efecto tributario, si expresamente la LIR o el RLIR se lo otorgan exigiendo el registro contable como requisito para admitir la deducción.

Atendiendo a ello, queda claro que las normas contables no generan un efecto jurídico y menos tributario por si solas; salvo que una norma tributaria expresa le otorgue tal efecto. Lo antes indicado es un elemento que me permite adelantar que la norma contable no es una norma jurídica.

Siguiendo esa misma línea el artículo V de los Principios Regulatorios de la "Ley General del Sistema Nacional de Contabilidad" (LGSNC) aprobada por la Ley N $^{\circ} 28708$ dispone la "Primacía de la legislación respecto a las normas contables". Ello implica que 
ante un conflicto entre la norma contable y la legislación (norma jurídica) esta última siempre prevalece.

Al existir tal disposición, cabe interpretar que la norma contable no califica, en el ordenamiento peruano, como una norma jurídica aun cuando se apruebe el empleo de determinadas normas contables en el país. En efecto, si las normas contables al ser aprobadas su empleo por el CNC en el país, hubiera implicado su incorporación como norma jurídica al ordenamiento nacional, no hubiera sido necesario que se contemple el artículo V de la LGSNC, ya que de haber existido conflicto con otra norma jurídica se habría determinado cual era la que primaba por rango de norma, o por especialidad, etc.

Por ello, resulta claro que el artículo V de la LGSNC constituye una norma que marca un hito insalvable, para aquellos que pretenden sustentar que las normas contables (MC, NIC y NIIF) califican como normas jurídicas e incluso se animan a plantear la existencia del derecho contable en el país.

Para la legislación nacional, las normas contables no califican como normas jurídicas; incluso, siempre que exista un conflicto primará la norma jurídica, sin importar el rango o jerarquía de la misma.

Adicionalmente, si la legislación nacional le desconoce la calidad de norma jurídica a las normas contables, no resulta posible sostener la existencia del derecho contable en Perú; como sí ocurre en otras latitudes.

Atendiendo a ello, no cabe duda que el artículo 223 de la LGS y el artículo 33 del RLIR constituyen normas jurídicas que nos remiten a procedimientos, disposiciones o pautas no jurídicas que deben ser empleadas por las sociedades para medir o determinar sus resultados de manera confiable y cierta.

Por otro lado, desde un aspecto formal para que una norma jurídica se origine válidamente y entre en vigencia, se deben cumplir con formalidades que son recogidas en los textos constitucionales.

Es por ello, que en los artículos 51, 102, 103 y 109 de la Constitución Política del Perú de 1993 se establece que: (a) la Constitución prevalece sobre toda norma legal; la ley, sobre las normas de inferior jerarquía, y así sucesivamente. (b) el Congreso se encuentra facultado para dar leyes y resoluciones legislativas, así como para interpretar, modificar o derogar las existentes, (c) la ley es obligatoria desde el día siguiente de su publicación en el diario oficial, salvo disposición contraria de la misma ley que postergue 
su vigencia total o parcialmente, (d) la ley se deroga sólo por otra ley o queda sin efecto por sentencia que declara su inconstitucionalidad.

De todo lo antes indicado, se evidencia que para que una norma jurídica se configure como tal y surta plenos efectos, es necesario que sea emitida por un órgano competente del Estado y sea publicada.

En el caso de las normas contables (MC, NIC y NIIF) no son dictadas por un ente competente del Estado, ya que el CNC sólo ordena su aplicación en el país, más no es quien dicta tales disposiciones. De igual forma, tales normas contables no cumplen con la exigencia de ser publicadas; ello implica que en el negado caso que fueran dictadas por un ente competente del Estado, "no cumplen con la condición mínima de su vigencia, como es su publicación en el Diario Oficial, a tenor de la jurisprudencia reiterada del Tribunal Constitucional en su sentencia No 0021-2003-AI/TC, entre otras." (Gamba Valega, 2014, p. 223-224)

Por lo expuesto consideramos que las normas contables (MC, NIC y NIIF) no pueden ser calificadas como normas jurídicas, ya que no reúnen las condiciones exigidas para ello.

Ahora bien, en el negado caso que las normas contables (MC, NIC y NIIF) fueran calificadas como normas jurídicas, sólo podría atribuírseles el rango legal correspondiente a una resolución del CNC, con el cual se oficializa su aplicación.

Bajo el entendido que las normas contables (MC, NIC y NIIF) no constituyen normas jurídicas, no pueden ser empleadas supletoriamente al amparo de la Norma IX del Título Preliminar del CT. Ello debido a que:

(a) La analogía es admitida, restrictivamente, para cubrir vacíos en normas tributarias, empleando para ello otra norma jurídica (dentro de las que no están comprendidas las normas contables) o los principios del derecho administrativo o principios generales del derecho.

(b) La analogía en el derecho tributario se encuentra limitado a aspectos distintos de los elementos esenciales del tributo. Ello debido a que de aplicarse analogía para cubrir vacíos en los aspectos esenciales del tributo, se configuraría una violación de la reserva de ley contemplada en el artículo 74 de la Constitución Política de 1993. 
(c) En el hipotético y negado caso que las normas contables calificarán como normas jurídicas y que se permitiera la aplicación de la analogía para los elementos esenciales del tributo; aún así no podría emplearse la Norma IX del Título Preliminar del CT. Ello debido a que, de calificar las normas contables como una norma jurídica; el rango de las mismas sería equivalente a las resoluciones del CNC y su aplicación también violaría la reserva de ley existente en el artículo 74 de la Constitución Política de 1993.

Por lo expuesto, consideramos que en todos aquellos pronunciamientos efectuados por SUNAT, el Tribunal Fiscal y el Poder Judicial en que empleen la Norma IX del Título Preliminar del CT, para incorporar disposiciones contables (como es el concepto de ingreso) a disposiciones tributarias, incurren en un error y en una violación al artículo 74 de la Constitución Política de 1993.

\subsubsection{Norma III del Título Preliminar del CT y normas contables}

Descartada la aplicación de la Norma IX del Título Preliminar del CT, resulta necesario determinar si las normas contables pueden ser calificadas como fuentes del derecho y utilizados al amparo de la Norma III del Título Preliminar del CT.

La Norma III del Título Preliminar del CT establece "como fuentes del derecho tributario las siguientes: (a) Las disposiciones constitucionales, (b) Los tratados internacionales aprobados por el Congreso y ratificados por el Presidente de la República, (c) Las leyes tributarias y las normas de rango equivalente, (d) Las leyes orgánicas o especiales que norman la creación de tributos regionales o municipales, (e) Los decretos supremos y las normas reglamentarias, (f) La jurisprudencia, (g) Las resoluciones de carácter general emitidas por la Administración Tributaria, (h) La doctrina jurídica.”

Rubio Correa (2011) define por fuente formal de derecho a "aquel procedimiento a través del cual se producen, válidamente, normas jurídicas que adquieren el rasgo de obligatoriedad propio del Derecho y, por lo tanto, la característica de ser impuestas legítimamente a las personas mediante los instrumentos de coacción del Estado.” (p.111)

Rubio Correa (2011) considera que las fuentes del derecho en general son cinco: (a) legislación, (b) jurisprudencia, (c) costumbre, (d) doctrina, (e) declaración de voluntad. (p. 113) Trasladadas tales fuentes de derecho al derecho tributario sufren las 
variaciones contenidas en la Norma III del Título Preliminar del CT; pero que en esencia guardan los mismos conceptos.

Debo mencionar que en el presente rubro me excuso de analizar las fuentes del derecho tributario detalladas en los literales (a), (b), (c), (d), (e), (f) y (g) de la Norma III del Título Preliminar del CT. Ello se origina debido a que: (i) Se determinó que la norma contable (MC, NIC y NIIF) no califica como una norma jurídica, y (ii) todas las fuentes del derecho tributario antes detalladas califican como normas jurídicas. Por ello, que carece de objeto pronunciarnos al respecto.

Atendiendo a lo antes expuesto, queda analizar si las normas contables (MC, NIC y NIIF) constituyen una fuente del derecho tributario por encontrarse comprendidas en la "doctrina".

Alzamora Valdez (1984), define a la doctrina como "el conjunto de opiniones de los jurisconsultos, emitidas con la finalidad teórica o con el objeto de facilitar la aplicación del derecho.” (p. 247) Este mismo autor explica que la doctrina como fuente formal "que no equivale al de las otras -ley, costumbre, jurisprudencia- no tiene más alcance que el de iluminar el camino para el estudio y la aplicación del derecho, y abrir nuevas perspectivas a la obra del legislador y del juez.” (p. 247)

Rubio Correa (2011), establece que la doctrina:

Es el conjunto de escritos aportados al Derecho a lo largo de toda su historia, por autores dedicados a describir, explicar, sistematizar, criticar y aportar soluciones dentro del mundo jurídico." (p. 196) Este mismo autor sostiene que "los textos legislativos no usan definir los términos que utilizan, al punto que muchas veces su simple lectura es inentendible para quien no ha estudiado Derecho. La doctrina suple todas estas limitaciones, y a veces deficiencias de la legislación. (p. 197)

En síntesis, podemos decir que las funciones doctrinales de describir, explicar, sistematizar, criticar y aportar soluciones, son parte esencial del sistema jurídico dentro de la familia romano-germánica, y que si bien la jurisprudencia puede eventualmente cumplir este papel, nunca llega a sustituir a la fuente doctrinal. (p. 200)

Sevillano Chavez (2016), resalta que la doctrina constituye una fuente del derecho tributario extralegal y que de todas las fuentes del derecho tributario, es la que cuenta con la menor importancia y una participación relativa. Esta misma autora considera que la 
doctrina como fuente del derecho tributario sólo tendrá alguna relevancia y validez en tanto pueda ser calificada como unánime o mayoritaria. (p. 79-80)

Cuando la Norma III del Título Preliminar del CT hace mención a la doctrina como fuente del derecho tributario, se está refiriendo a la doctrina jurídica y no a la doctrina de cualquier otra ciencia.

Técnicamente resulta difícil calificar a las normas contables (MC, NIC y NIIF) como parte de la doctrina jurídico tributaria; sin embargo, al definir y precisar conceptos (tal como el caso de los "ingresos") que son reconocidos en el derecho tributario, puede sostenerse que tales normas contables pueden ser tratadas como elementos de la doctrina y por ende como una fuente de derecho tributario.

No deseo culminar el análisis de la Norma III del Título Preliminar del CT, sin mencionar que como parte de este tema llamó mi atención, la opinión vertida por Bravo Cucci (2014) respecto que las normas contables (MC, NIC y NIIF) se encuentran incorporadas al ordenamiento jurídico nacional, es decir, califican como normas jurídicas. (p. 253) Atendiendo a ello, las normas contables calificarían como fuente del derecho tributario (Norma III del Título Preliminar del CT), pero no a nivel de doctrina; sino en alguno de los niveles correspondientes a normas jurídicas tales como (a) leyes tributarias y normas de rango equivalente, o (b) decretos supremos y las normas reglamentarias.

En efecto, Bravo Cucci (2014) manifiesta que las normas contables (MC, NIC y NIIF) constituyen normas jurídicas debido a que: (a) El artículo 223 de la LGS reconoce tales normas contables y las hace de obligatorio cumplimiento para las sociedades reguladas por tal cuerpo legal, y (b) Las normas contables (MC, NIC y NIIF) que por Resolución del Consejo Normativo de Contabilidad ordena su aplicación en el país, son insertadas en el ordenamiento jurídico nacional. Del análisis efectuado por BRAVO CUCCI, detallado en las líneas precedentes, se infiere que tal autor entiende que la disposición del artículo 223 de la LGS califica como una norma de remisión, ya que tal cuerpo normativo auto incorpora el contenido de otra norma (MC, NIC y NIIF) sin tener que incluir o reproducir el texto de las normas contables. (p. 253)

Por lo expuesto al tratar la Norma IX del Título Preliminar del CT, al lector le resultará sencillo conocer nuestra posición, contraria a la planteada por BRAVO CUCCI. En efecto, las normas contables (MC, NIC y NIIF) no constituyen normas jurídicas, ya 
que no cumplen con los aspectos sustantivos y de forma de las mismas e incluso el artículo V de la LGSNC hace notorio que las normas contables no constituyen norma jurídica.

Adicionalmente, por integración analógica no es posible incorporar al ordenamiento jurídico nacional conceptos (normas contables) que no califican como normas jurídicas.

Por ello, considero que la única posibilidad de calificar a las normas contables como fuente del derecho tributario, es otorgándole el carácter de doctrina.

\subsection{Disposiciones Contables}

El párrafo 70 del MC define por "ingreso" a "los incrementos en los beneficios económicos, producidos a lo largo del ejercicio, (...) Que dan como resultado aumentos del patrimonio neto. No están relacionados con las aportaciones de los propietarios a este patrimonio."

El párrafo 74 del MC establece que:

La definición de ingresos incluye tanto a los ingresos ordinarios como las ganancias."

Para tal efecto, se entiende por "ingresos ordinarios" a los que "surgen en el curso de las actividades ordinarias de la empresa, y corresponden a una variada gama de denominaciones, tales como ventas, honorarios, intereses, dividendos, alquileres y regalías.

El párrafo 92 del MC dispone que los ingresos deben ser reconocidos en el estado de ganancias y pérdidas, "cuando ha surgido un incremento en los beneficios económicos futuros, relacionado con un incremento en los activos o una disminución en los pasivos, y además el importe del ingreso pueda valorarse con fiabilidad."

De acuerdo con el párrafo 93 del MC para el reconocimiento del ingreso es necesario que el mismo se encuentre devengado, es decir, que (i) puedan ser valorados, y (ii) posean un grado de certidumbre.

\subsubsection{NIC 18 - Ingresos}

La NIC 18 referida a "ingresos", establece que los ingresos se presentan en la preparación de los estados financieros como incremento de flujos o de activos, o disminución de 
pasivos; que resultan en un incremento patrimonial, diferente de aquellas cuentas de patrimonio neto proveniente de aportes de los accionistas. (párrafo 2, NIC 18).

Atendiendo a ello, se define por ingresos a:

La entrada bruta de beneficios económicos, durante el período, surgidos en el curso de las actividades ordinarias de una entidad, siempre que tal entrada de lugar a un aumento en el patrimonio neto, que no esté relacionado con las aportaciones de los propietarios de ese patrimonio. (párrafo 7, NIC 18).

Conforme a la NIC 18 para que califiquen como ingresos las entradas de beneficios económicos deben ser recibidos por cuenta propia, es decir, deben ser de propiedad de quien los recibe.

A manera de ejemplo la NIC 18 trata el caso de los comisionistas y otros, estableciendo que "en una relación de comisión, entre un principal y un comisionista, las entradas brutas de beneficios económicos del comisionista incluyen importes recibidos por cuenta del principal, que no suponen aumentos en el patrimonio neto de la entidad. Los importes recibidos por cuenta del principal no constituirán ingresos, que quedarán limitados en tal caso a los importes de las comisiones.” (párrafo 8, NIC 18).

Por otro lado, en el Apéndice A de la NIIF 15 se define por "ingresos" a los "Incrementos en los beneficios económicos, producidos a lo largo del periodo contable, en forma de entradas o incrementos de valor de activos o bien decrementos de los pasivos, que dan como resultado aumentos en el patrimonio, y no están relacionados con las aportaciones de los propietarios."

\subsubsection{Gaming - AICPA}

El AICPA publica la "AICPA Audit and Accounting Guide Gaming" 20 , desarrollada para ayudar al manejo y preparación de los estados financieros de las empresas del sector juego de azar de acuerdo con las U.S. GAAP.

El párrafo 3.07 de la "AICPA Audit and Accounting Guide Gaming" brinda la siguiente definición de "Gross Gaming Revenue” (Ingresos Brutos del Juego): 
is the difference between gaming wins and losses from banked games before deducting incentives or adjusting for changes in progressive jackpot liability accruals.

$(\ldots)$

For slot machines, gross gaming revenue is computed in accordance with the formula in paragraph 3.28.

Por otro lado, en el numeral 3.28 de la "AICPA Audit and Accounting Guide Gaming" se establece que:

Gross gaming revenue is normally computed by machine, by denomination and in total.

Slot machine gross gaming revenue is typicalley computed as follows:

Cash and tickets removed from the currency acceptors US \$2,000

Plus:

Coins removed from drop buckets

US $\$ 2,000$

Electronic money transfers from wagering

Account to the machine

$\underline{\text { US } \$ 1,000}$

Total drop

US $\$ 5,000$

Less:

Tickets issued by the machine

(US \$1,000)

Fills

(US \$ 1,000)

Hand paid jackpots

(US \$ 1,000)

Electronic money transfers from the machine to

A wagering account

(US \$1,000)

Plus or (minus) change in the hopper balance

(US \$ 200)

Total deductions before gross gaming revenue

(US \$ 4,200)

Gross gaming Revenue (Win)

US \$ 800

De todo lo antes detallado, se evidencia que sólo califican como ingresos para efectos contables, aquellos flujos de recursos que puedan ser medidos confiablemente y que incrementen el activo de la empresa, es decir, cuando sean considerados como recursos de propiedad de quien los recibió. 
En aquellos casos en que un particular obtenga fondos como consecuencia de su actividad ordinaria; pero los mismos no puedan ser reconocidos como de su propiedad, no generarán un incremento del activo y por ende no deben ser reconocidos como ingresos.

Como lo manifestamos en el capítulo II del presente trabajo, las disposiciones de la LJ obligan a los operadores de casinos y/o salas de máquinas tragamonedas a fijar un retorno no menor del 85\%. Ello implica que las apuestas recibidas (Coin In) por los operadores de juego de azar no son de su libre disposición; por lo que, no pueden ser reconocidos como incrementos en el activo de tales empresas, ni como ingresos para efectos contables.

Siguiendo los criterios previamente expuestos, el párrafo 3.07 de la “AICPA Audit and Accounting Guide Gaming”, evidencia que los ingresos brutos derivados del juego son el diferencial entre las apuestas recibidas (Coin In) y los premios pagados (Coin Out) y Hand Pay. De esta manera, contablemente se reconoce que las apuestas no constituyen un flujo de recursos que deben ser reconocidos como de propiedad de los operadores de casinos y salas de máquinas tragamonedas; por lo que, no se configura un incremento del activo.

El ingreso bruto derivado de la actividad de casinos y salas de máquinas tragamonedas, se encuentra constituido por el remanente de restar a las apuestas, los premios pagados en un determinado período. 


\section{CAPÍTULO V: PRONUNCIAMIENTOS}

\subsection{DGJCMT del MINCETUR}

El 02 de septiembre de 2010 la Sociedad Nacional de Juegos de Azar, formuló a la DGJCMT del MINCETUR las siguientes consultas:

(1) ¿Cuál es la naturaleza del Coin In, del Coin Out y del Hand Pay, conforme las disposiciones legales que regulan la actividad de máquinas tragamonedas?;

(2) ¿El “Coin In” califica como un ingreso del operador de salas de máquinas tragamonedas, conforme las disposiciones contables que regulan tal materia (NIC 18)?;

(3) ¿Los fondos que los operadores de salas de máquinas tragamonedas reciben como consecuencia del canje de fichas, constituyen ingresos para éstos, conforme las disposiciones legales y contables que regulan tal materia?;

(4) En caso las respuestas a las preguntas 2 y 3 sean que el "Coin In" no es ingreso y que los fondos recibidos por el operador derivados del canje de fichas tampoco califica como ingreso; ¿Cuál es el concepto que los operadores de máquinas tragamonedas deben reconocer como ingreso conforme las disposiciones legales y contables que los regulan?

Posteriormente, la Dirección General de Juegos de Casinos y Máquinas Tragamonedas del MINCETUR dio respuesta a la consulta formulada, mediante el Oficio No 2447-2010MINCETUR/VMT/DGJCMT, en el que manifestó:

- (Respuesta a la pregunta 1 de la consulta)

Los términos en idioma inglés: "coin in", "coin out" y "hand pay", representan el total de dinero ingresado por concepto de apuestas en las máquinas tragamonedas, el total de dinero entregado al jugador por concepto de premios como consecuencia de la verificación de una jugada ganadora y el pago manual que realiza el personal operador a favor del jugador por el concepto antes referido, respectivamente.

- (Respuesta a la pregunta 2 de la consulta)

De acuerdo con la Norma Internacional de Contabilidad (NIC) $\mathrm{N}^{\circ} 18$, se define a los ingresos como "la entrada bruta de beneficios económicos, durante el período, surgidos en el curso de las actividades ordinarias de una entidad, siempre que tal entrada de lugar 
a un aumento en el patrimonio neto que no esté relacionado con las aportaciones de los propietarios de ese patrimonio.

Por su parte, el patrimonio se encuentra conformado por las siguientes partidas contables: capital social, excedente de revaluación, reserva legal y resultados acumulados; representando el patrimonio neto la participación residual de los propietarios o accionistas sobre los activos de la empresa.

En ese sentido, en atención a la norma de contabilidad antes indicada y a lo que contablemente se entiende por patrimonio neto, el "coin in" no calificaría como ingreso, toda vez que el ingreso en la explotación de los juegos de máquinas tragamonedas se configura una vez se descuenten del "coin in" los premios otorgados.

- (Respuesta a la pregunta 3 de la consulta)

En la explotación de máquinas tragamonedas, la transacción que se realiza entre el operador y los clientes es la de canje de medios de juegos por dinero o viceversa. Las apuestas así como el resultado de las mismas, se registran en las máquinas tragamonedas, las mismas que a su vez, reconocen los premios obtenidos por los jugadores tanto en créditos como en el valor monetario que representan. En ese sentido, el canje de fichas no constituye un ingreso de acuerdo con lo señalado en el punto 2 del presente Oficio.

- (Respuesta a la pregunta 4 de la consulta)

De acuerdo con lo establecido en el literal a) del artículo $61^{\circ}$ del Decreto Supremo No0092002-MINCETUR, debe entenderse por ingreso neto mensual a la diferencia entre el monto total recibido por las apuestas o dinero destinado al juego y el monto total de los premios entregados en el mismo mes.

Si consideramos la definición en la Norma Internacional de Contabilidad (NIC) $\mathrm{N}^{\circ} 18$, identificamos al ingreso de los titulares de una autorización para la explotación de máquinas tragamonedas como el ingreso neto mensual antes indicado.

De lo manifestado por la DGJCT/del MINCETUR en el Oficio $\mathrm{N}^{\mathrm{o}}$ 2447-2010MINCETUR/VMT/DGJCMT se evidencia que en la actividad de casinos y/o salas de máquinas tragamonedas el "coin in" no constituye ingreso, conforme las disposiciones que regulan la actividad de juegos de azar y la NIC 18.

Para mayor detalle, en los Anexos del presente trabajo hemos consignado una copia del Oficio No 2447-2010-MINCETUR/VMT/DGJCMT. 


\subsection{SUNAT}

\subsubsection{Informe $\mathrm{N}^{\circ}$ 211-2006-SUNAT/2B0000}

En virtud del literal i) del artículo 92 y el artículo 93, ambos del CT, se formuló la siguiente consulta a SUNAT:

En relación con la determinación de la base de cálculo para el pago a cuenta del Impuesto a la Renta, que se encuentran obligadas a efectuar las empresas explotadoras de máquinas tragamonedas, ¿se debe considerar el concepto de "ingreso neto" regulado por el inciso b) del artículo 38.2 de la Ley $\mathrm{N}^{\circ}$ 27153? (página 1, Informe $\mathrm{N}^{\circ}$ 211-2006SUNAT/2B0000)

SUNAT dio respuesta emitiendo el Informe $\mathrm{N}^{\mathrm{o}}$ 211-2006-SUNAT/2B0000, con el cual se concluyó que:

Los sujetos pasivos del Impuesto a los Juegos de Casino y de Máquinas Tragamonedas, deben efectuar sus pagos a cuenta del Impuesto a la Renta de tercera categoría considerando el concepto de ingreso neto contenido en la propia regulación de este último impuesto y no el contenido en la Ley $\mathrm{N}^{\circ}$ 27153. (página 3, Informe $\mathrm{N}^{\circ}$ 211-2006-SUNAT2B0000)

El Informe $N^{o}$ 211-2006-SUNAT/2B0000 fue empleado como sustento en diversas fiscalizaciones efectuadas por SUNAT a empresas operadoras de casinos y/o salas de máquinas tragamonedas; en las que se observó la determinación de los anticipos de tercera categoría del IR. Ello debido a que en tales fiscalizaciones se estableció que:

el contribuyente determina sus pagos a cuenta del Impuesto a la Renta considerando el concepto de ingreso neto contenido en la Ley $\mathrm{N}^{\circ} 27153$ - Ley que regula la explotación de los juegos y máquinas tragamonedas (diferencia resultante entre el ingreso total percibido en un mes por concepto de apuestas o dinero destinado al juego y el monto total de los premios otorgados el mismo mes), es decir, sin observar lo establecido en el sexto párrafo del artículo $85^{\circ}$ del Texto Único Ordenado del Impuesto a la Renta aprobado por D.S. 179-2004-EF y modificatorias, en lo referente a la definición de ingreso netos: "Para efecto de lo dispuesto en este artículo, se consideran ingresos netos el total de ingresos gravables de la tercera categoría, devengados en cada mes, menos las devoluciones, bonificaciones, descuentos y demás conceptos de naturaleza similar que respondan a la costumbre de la plaza, e impuesto calculado al importe determinado aplicando la tasa a 
que se refiere el primer párrafo del Artículo 55 de esta ley. (...) (página 1, resultado del requerimiento $\mathrm{N}^{\circ} 1322100000315$, SUNAT)

Ahora bien, las observaciones formuladas por SUNAT carecían de sustento, ya que los operadores de casinos y salas de máquinas tragamonedas determinan los pagos a cuenta de tercera categoría del IR en función a lo establecido en el artículo 85 de la LIR; sin embargo, recogen los conceptos contemplados en el artículo 38 de la Ley $\mathrm{N}^{\mathrm{o}} 27153$, ya que esa norma contiene una definición de ingreso acorde con su actividad y que es coincidente con las disposiciones del MC y la NIC 18.

En efecto, el artículo 38 de la Ley $N^{\circ} 27153$ califica como ingreso neto mensual a la diferencia entre el monto de las apuestas y el monto total entregado por los premios otorgados en el mismo mes.

Coincidimos en lo manifestado por el Informe $\mathrm{N}^{\mathrm{o}}$ 211-2006-SUNAT/2B0000, en que las disposiciones contenidas en el artículo 38 de la LJ constituyen normas aplicables sólo al IJ y no resultan aplicables al IR; sin embargo, del mencionado artículo 38 de la LJ se desprende la naturaleza jurídica del:

(a) canje de fichas,

(b) coin in,

(c) al coin out y el hand pay, y

(d) al remanente a favor del operador de la sala de máquinas tragamonedas.

Si adicionalmente a los conceptos contenidos en el artículo 38 de la LJ, éstos se complementan con las disposiciones del MC y la NIC 18, se obtiene un análisis que con claridad permite determinar el concepto de ingreso.

El Informe N² 211-2006-SUNAT/2B0000 fue empleado por SUNAT en múltiples oportunidades para sustentar los reparos a la forma de determinación de los anticipos de tercera categoría del IR, efectuadas por los operadores de casinos y/o salas de máquinas tragamonedas. Sin embargo, tal Informe no negó, ni estableció la prohibición de emplear las normas de la LJ para analizar la naturaleza jurídica del:

- canje de fichas,

- "coin in",

- el "coin out y hand pay", y 
- el remanente a favor del operador de la sala de máquinas tragamonedas.

y determinar cuál de estos conceptos califica tributariamente como un ingreso aplicable al artículo 85 de la LIR.

De igual forma, el Oficio No 211-2006-SUNAT/2B0000 sólo estableció que para determinar los anticipos mensuales del IR, se debe emplear el concepto de ingreso neto contenido en el artículo 85 de la LIR; sin embargo, en ningún momento el oficio estableció que el ingreso neto estuviera constituido por el COIN IN.

Atendiendo a ello, en las fiscalizaciones efectuadas por SUNAT, se efectuó una interpretación errónea del Oficio No 211-2006-SUNAT/2B0000.

\subsubsection{Informe $\mathrm{N}^{\circ}$ 188-2015-SUNAT/5D0000}

En virtud del artículo 92 del CT, la Sociedad Nacional de Juegos de Azar, formuló la siguiente consulta a SUNAT:

Para efecto que los sujetos que explotan juegos de casinos y máquinas tragamonedas determinen los ingresos netos a que se refiere el artículo $85^{\circ}$ de la Ley del Impuesto a la Renta:

a) ¿Deben considerar dentro de los ingresos gravables de la tercera categoría, devengados en cada mes, el monto total recibido por las apuestas o dinero destinado al juego en cada mes, o la diferencia entre dicho monto y el monto total entregado por los premios otorgados en el mismo mes? (Consulta expediente $\mathrm{N}^{\circ}$ 000-TI0001-2015-00203376-3)

En respuesta a la consulta formulada, SUNAT emitió el Informe $\mathrm{N}^{\circ}$ 188-2015SUNAT/5D0000, en el cual se concluyó que:

Para efecto de determinar los ingresos netos a que se refiere el artículo $85^{\circ}$ de la Ley del Impuesto a la Renta, los sujetos que explotan juegos de casinos y máquinas tragamonedas, deben considerar la diferencia entre el monto total recibido por las apuestas o dinero destinado al juego en cada mes y el monto total entregado por los premios otorgados en el mismo mes. (página 5, Informe $\mathrm{N}^{\circ}$ 188-2015-SUNAT/5D0000).

El mencionado Informe $\mathrm{N}^{\circ}$ 188-2015-SUNAT/5D0000, se sustentó en los siguientes fundamentos:

(a) "En lo que respecta a "ingresos netos", es del caso mencionar que en el rubro análisis del Informe $\mathrm{N}^{\mathrm{0}}$ 045-2012-SUNAT/4B0000 se ha indicado que para 
efectos del Impuesto a la Renta, constituyen tales ingresos los obtenidos por la empresa con ocasión del desarrollo de su actividad, menos los descuentos, bonificaciones, devoluciones y similares conceptos propios de la plaza.”(página 2, Informe $\mathrm{N}^{\circ}$ Informe $\mathrm{N}^{\circ}$ 188-2015-SUNAT/5D0000).

(b) SUNAT en aplicación de la Norma IX del Título Preliminar del CT, recurre a la definición contable de "ingreso" contenida en el párrafo 7 de la NIC 18, según la cual señala que un ingreso "es la entrada bruta de beneficios económicos, durante el período, surgido en el curso de las actividades ordinarias de una entidad, siempre que tal entrada dé lugar a un aumento en el patrimonio, que no esté relacionado con las aportaciones de los propietarios de ese patrimonio." (página 3, Informe $\mathrm{N}^{\circ}$ 188-2015-SUNAT/5D0000).

(c) Se remite al párrafo 8 de la SIC 27, estableciendo que para el reconocimiento de ingresos se deben

considerar factores tales como si hay una responsabilidad continuada en forma de obligaciones de desempeño, futuras y significativas, que sean necesarias para obtener las cuotas, si hay riesgos que se han retenido, los términos de cualquier acuerdo de garantía o el riesgo de reembolso de las cuotas. Entre los indicadores que, de forma individual, demuestran que es inadecuado el reconocimiento del total de la cuota como ingreso cuando se recibe, si se recibió al comienzo del acuerdo, se incluyen la existencia de obligaciones, la posibilidad de reembolsar cualquier importe de la cuota, entre otros. (página 3, Informe $N^{\circ}$ 188-2015-SUNAT/5D0000)

(d) Establece que:

para efectos del reconocimiento de ingresos de actividades ordinarias de una empresa se deberá considerar como ingresos lo dispuesto por el párrafo 7 de la NIC 18, sin perjuicio de que por ciertas actividades se tomen en cuenta para su determinación la existencia de obligaciones que constituyen una condición para llevar a cabo la actividad que motiva el ingreso. (página 3, Informe $\mathrm{N}^{\circ}$ 188-2015-SUNAT/5D0000).

(e) Que, al amparo del artículo 10 de la Ley $\mathrm{N}^{\circ} 27153$, existe una obligación legal de un retorno mínimo al público del $85 \%$ de las apuestas efectuadas por el público.

(f) Para determinar el ingreso neto para efectos de los anticipos de tercera categoría del IR, los operadores de casinos y/o salas de máquinas tragamonedas

deben considerar dentro de los ingresos gravables devengados en cada mes, la diferencia entre el monto total recibido por las apuestas o dinero destinado al juego 
en cada mes, y el monto total entregado por los premios otorgados en el mismo mes, teniendo en cuenta que para efectos del reconocimiento de ingresos de actividades ordinarias de estas empresas se debe considerar como ingresos lo dispuesto por el párrafo 7 de la NIC 18 menos las obligaciones que constituyen una condición para llevar a cabo la actividad que motiva el ingreso. (página 4, Informe $\mathrm{N}^{\circ}$ 188-2015SUNAT/5D0000).

Tal como lo manifestamos en el capítulo III del presente trabajo, no resulta posible emplear las normas contables (MC, NIC y NIIF) para integrarlas analógicamente (Norma IX del Título Preliminar del CT) y para cubrir la omisión existente en una norma jurídica (laguna de ley); ya que el empleo de la integración analógica sólo resulta aplicable entre normas jurídicas o con principios jurídicos.

Tal como lo sostuve en el capítulo III del presente trabajo, el MC y la NIC 18 no califican como normas jurídicas; por lo cual, no pueden ser empleadas para cubrir laguna de ley existente en el artículo 85 de la LIR.

En todo caso, hubiera sido recomendable la aplicación de la Norma III del Título Preliminar del CT y calificar al MC y la NIC 18 como parte de la doctrina, incorporándolo como fuente del derecho tributario. De esta manera, la Administración Tributaria habría estado facultada para aplicar el MC y la NIC 18 a la consulta formulada.

Cabe mencionar que SUNAT cuando emite informes como el antes detallado, en los que se tratan materias normativas que configuran lagunas de ley, tales como las definiciones de "ingreso" y del "devengado" en la LIR; debería proceder conforme a lo dispuesto en el artículo 95 del CT, según el cual:

En los casos en que existiera deficiencia o falta de precisión en la norma tributaria, no será aplicable la regla que contiene el artículo anterior, debiendo la Superintendencia Nacional de Administración Tributaria - SUNAT proceder a la elaboración del proyecto de ley o disposición reglamentaria correspondiente. Cuando se trate de otros órganos de la Administración Tributaria, deberán solicitar la elaboración del proyecto de norma legal o reglamentaria al Ministerio de Economía y Finanzas.

Atendiendo a ello, sería deseable que la Administración Tributaria ejerciera diligentemente el rol que le fue conferido por el CT, ya que de ejercerla permitiría una mayor seguridad jurídica a los contribuyentes. 


\subsubsection{Informe $\mathrm{N}^{\circ} 002-2017-\mathrm{SUNAT} / 5 \mathrm{D} 0000$}

La Intendencia Nacional Jurídica de SUNAT emitió el Informe $\mathrm{N}^{\mathrm{o}}$ 002-2017SUNAT/5D0000, el cual en su conclusión tercera manifestó que:

3. No todo el dinero que es ingresado en la cuenta de la referida empresa, por concepto de apuestas, constituye ingreso para efectos del impuesto a la renta, sino únicamente el importe que quede en la citada cuenta, luego de pagados los premios a los apostadores que acertaron, encontrándose este gravado con dicho impuesto.

Si bien el Informe No 002-2017-SUNAT/5D0000, fue emitido para analizar las apuestas obtenidas por los locales de apuestas deportivas, una de las modalidades de juegos de azar y apuestas existentes en el país; de tal informe se evidencia que SUNAT reitera la conclusión planteada en el Informe No 0188-2015-SUNAT/5D0000 e incluso éste último informe es citado por SUNAT en el Informe No 002-2017-SUNAT/5D0000, como un antecedente de la opinión de tal institución.

Ahora bien, el Informe $N^{\circ}$ 002-2017-SUNAT/5D0000, resulta relevante porque confirma y reitera la opinión vertida en el Informe $N^{\circ}$ 0188-2015-SUNAT/5D0000, referida a que (a) las apuestas obtenidas por locales de juegos de azar y apuestas no califican como ingresos para efectos tributarios; (b) los ingresos de los locales de juegos de azar y apuestas se obtienen de restar a las apuestas obtenidas en un determinado período, los premios pagados a los apostadores en el mismo período.

Este informe incurre en el mismo error de aplicación de la Norma IX del Título Preliminar del CT, que fue descrito respecto del Informe $\mathrm{N}^{\circ}$ 188-2015-SUNAT/5D0000; por lo cual, nos remitimos a lo manifestado en el numeral 5.2.2.

Adicionalmente, si bien coincido con la opinión vertida por SUNAT, cabe mencionar que en el Informe $\mathrm{N}^{\circ}$ 002-2017-SUNAT/5D0000 en el caso del ingreso de casinos y salas de máquinas tragamonedas existe legislación que establece la obligación del retorno mínimo al público y que brinda una definición de conceptos que permiten determinar qué califica como ingreso. Sin embargo, en las actividades de apuestas deportivas por su naturaleza no resulta factible garantizar un retorno mínimo al público, así como no existe legislación que defina qué constituye ingreso para tal actividad. 


\subsection{Tribunal Fiscal}

SUNAT emitió diversas resoluciones de intendencia, en las cuales se declararon infundadas las reclamaciones interpuestas por los operadores de casinos y/o salas de máquinas tragamonedas. Es por ello, que tales contribuyentes interpusieron apelaciones que fueron elevadas al Tribunal Fiscal, las mismas que fueron resueltas por tal órgano colegiado con las RTFs Nº 00908-2-2016, 01879-2-2016, 02099-5-2016, 02100-5-2016 y 08632-5-2016.

Tal como lo he manifestado en capítulo II del presente trabajo los argumentos planteados por los contribuyentes fueron los siguientes:

(b) Net Win califica como ingreso: Se planteó que el "ingreso", para efecto de determinar los anticipos de tercera categoría del IR, es el diferencial (Net Win) de restar a las apuestas (Coin In), los premios (Coin Out) entregados en el mismo periodo.

Tal posición fue sustentada en base a: (i) la obligación de retorno mínimo al público del 85\% de las apuestas (Coin In) efectuadas, conforme al artículo 10 de la LJ; (ii) el concepto de ingreso neto mensual existente en el literal a) del numeral $38.2 \mathrm{del}$ artículo 38 de la LJ que contiene conceptos que permiten definir cuál es el ingreso derivado de la actividad de casinos y/o salas de máquinas tragamonedas, (iii) el concepto de "ingreso" necesario para determinar los anticipos de tercer categoría del IR, es el correspondiente a lo establecido en el párrafo 70 del Marco Conceptual de las NIIF y el párrafo 7 de la NIC 18, según las cuales el Net Win cumple con las exigencias de las normas contables para ser calificado como ingreso.

(b) Coin In como ingreso: En el negado caso que el Coin In califique como ingreso, para efectos de los anticipos de tercera categoría del IR; debe tenerse presente que el artículo 85 de la LIR establece que la base imponible de los anticipos se encuentra constituidas por el ingreso neto devengado en el mes, menos las devoluciones, bonificaciones, descuentos y demás conceptos de naturaleza similar que

\section{respondan a la costumbre de la plaza.}

Atendiendo a ello, se admiten como conceptos que pueden ser deducidos del ingreso neto, a las devoluciones, bonificaciones, descuentos, y demás conceptos de naturaleza similar que respondan a las costumbres de la plaza. 
Cabe indicar que en el artículo 85 de la LIR al hacer expresa mención a "demás conceptos de naturaleza similar que respondan a las costumbres de la plaza", abre la posibilidad de deducir conceptos que por su naturaleza no califiquen como devoluciones, bonificaciones, descuentos, pero que por el tipo de actividad resulte evidente que tal rubro constituye una reducción usual y necesaria para que el contribuyente obtenga los ingresos netos afectos al anticipo de tercera categoría del IR.

En el caso que nos ocupa, los premios ("coin out" y "hand pay") constituyen rubros que forman parte de la propia naturaleza de la actividad y que sin ellos los juegos de azar no existirían. Ello implica que los premios se originan por la propia costumbre de la plaza. Sin perjuicio de lo antes detallado, tales premios y los porcentajes mínimos de retorno constituyen obligaciones legales contenidas en la LJ.

En consecuencia, la naturaleza jurídica de los premios ("coin out" y "hand pay") permite calificarlos como un rubro que se encuentra contenido en "demás conceptos de naturaleza similar que respondan a las costumbres de la plaza"; por lo cual, deben ser deducidos del ingreso neto empleado para determinar los anticipos de la tercera categoría del IR.

A este respecto, el TF en las RTFs No 00908-2-2016, 01879-2-2016, 02099-5-2016, 02100-5-2016 y 08632-5-2016, brinda los siguientes conceptos:

(i) “Rebaja": En las RTFs No No 6725-2-2014 y 09688-1-2004 se precisa que la rebaja es una "disminución sobre el precio habitual de venta que una empresa concede a sus clientes y una forma de incentivar, en el largo o en el corto plazo, la compra de sus productos y la fidelidad de sus clientes."

(ii) "Bonificaciones": El TF en la RTF No 8049-3-2010 establece que "las bonificaciones sobre ventas corresponden a las rebajas que se conceden sobre el precio de venta, independientemente de las fechas de vencimiento de los pagos respectivos y añade que se entiende la bonificación como una ventaja en las transacciones realizadas, equivalente a una prima, comisión o rebaja."

(iii) "Conceptos de naturaleza similar que respondan a las costumbres de la plaza": En tal concepto "sólo deben incluirse supuestos que, aunque con 
otra denominación, impliquen una rebaja sobre el pago que debe efectuarse por la transacción."

Por ello, el TF concluye que

el otorgamiento de premios por parte de las empresas dedicadas a la explotación de juegos de casino y máquinas tragamonedas, no busca rebajar o disminuir las sumas de dinero que entregan sus clientes por las operaciones que efectúan con ellas, sino que constituyen una contraprestación aleatoria a sus apuestas, no procede considerar los montos de tales premios como devoluciones, bonificaciones, descuentos o demás conceptos de naturaleza similar que respondan a la costumbre de la plaza (...)

En los procedimientos de apelación que fueron objeto de las RTFs $\mathrm{N}^{\circ}$ 00908-2-2016, 02099-5-2016, el contribuyente sólo empleó el argumento mediante el cual se reconoce al "coin in" como ingreso y los premios deben ser calificados como "conceptos de naturaleza similar que respondan a la costumbre de la plaza”.

Por otro lado, en las apelaciones objeto de las RTFs 02099-5-2016 y 02100-52016, el contribuyente empleo como argumentos de defensa:

(a) El referido a que las apuestas (Coin In) no califica como ingreso y en la actividad de casinos y/o salas de máquinas tragamonedas el ingreso se configura en el Net Win (diferencial de restar a las apuestas -Coin In--, los premios pagados - Coin Out).

(b) En el negado caso que lo detallado en el literal (a) no fuese correcto, se reconoce al "coin in" como ingreso y los premios deben ser calificados como "conceptos de naturaleza similar que respondan a la costumbre de la plaza".

Las Salas 2 y 5 del TF al emitir las RTF No 00908-2-2016, 02099-5-2016 y 021005-2016, han evidenciado que tal órgano colegiado mantiene una posición contraria a la planteada por SUNAT en el Informe No 188-2015-SUNAT/5D0000.

En efecto, de las RTFs detalladas en el párrafo precedente se evidencia que las Salas 2 y 5 del TF consideran que para efectos de la determinación de los anticipos de tercera categoría del IR, que deben determinar los operadores de casinos y máquinas tragamonedas, el concepto ingreso se encuentra conformado por la totalidad de las apuestas (Coin In) efectuadas, ello en virtud a los siguientes argumentos:

(i) Las RTFs en mención sólo se pronuncian respecto del argumento detallado en el literal (b) precedente, sosteniendo que "las devoluciones, bonificaciones y 
descuentos constituyen rebajas que una empresa concede a sus clientes en las transacciones realizadas y en este sentido, en el rubro "conceptos de naturaleza similar que respondan a la costumbre de la plaza" solo deben incluirse supuestos que, aunque con otra denominación, impliquen también una rebaja”. (RTF $\mathrm{N}^{\circ}$ 00908-2-2016, p.3). Tal criterio se sustenta en las RTF No 6725-2-2014, 09688$1-2004$ y $8049-3-2010$.

(ii) El premio que es un hecho futuro e incierto y que aleatoriamente puede obtener cualquiera de las personas que efectuó la apuesta en el local de casino y/o sala de máquinas tragamonedas, se sostiene que es una contraprestación a sus apuestas. Por ello, en la RTF $N^{\circ} 00908-2-2016$ se sostiene que:

el otorgamiento del premio no busca rebajar o disminuir las sumas de dinero que entregan sus clientes por las operaciones que efectúan con ellas, sino que constituyen una contraprestación aleatoria a sus apuestas, no procede considerar los montos de tales premios como devoluciones, bonificaciones, descuentos o demás conceptos de naturaleza similar que respondan a la costumbre de la plaza (...) (p. 3 y 4$)$

La Sala 5 del TF en las RTFs antes citadas omitieron pronunciarse respecto que el "ingreso", para efecto de determinar los anticipos de tercera categoría del IR, es el diferencial (Net Win) de restar a las apuestas (Coin In), los premios (Coin Out) entregados en el mismo periodo.

Tal posición fue sustentada en base a: (i) la obligación de retorno mínimo al público del 85\% de las apuestas (Coin In) efectuadas, conforme al artículo 10 de la LJ; (ii) el concepto de ingreso neto mensual existente en el literal a) del numeral 38.2 del artículo 38 de la LJ que contiene conceptos que permiten definir cual es el ingreso derivado de la actividad de casinos y/o salas de máquinas tragamonedas, (iii) el concepto de "ingreso" necesario para determinar los anticipos de tercer categoría del IR, es el correspondiente a lo establecido en el párrafo 70 del Marco Conceptual de las NIIF y el párrafo 7 de la NIC 18, según las cuales el Net Win cumple con las exigencias de las normas contables para ser calificado como ingreso. 


\subsection{Poder Judicial}

El Décimo Noveno Juzgado Contencioso Administrativo en la Especialidad Tributaria Aduanera de la Corte Superior de Justicia de Lima emitió la sentencia en el Expediente No 05325-2016-0-1801-JR-CA-19, mediante la cual se declaró fundada en todos sus extremos la demanda contenciosa administrativa y declaró la nulidad de las RTFs $\mathrm{N}^{\circ}$ 00908-2-2016 у 01879-2-2016.

En los considerandos de la indicada sentencia el juzgado sostiene que:

(a) El concepto de ingreso no se encuentra definido en la LIR.

(b) Es necesario recurrir a las reglas de interpretación de las normas tributarias conforme el CT.

(c) La Norma IX del Título Preliminar del CT, dispone que en lo no previsto por las normas tributarias pueden aplicarse normas distintas a las tributarias siempre que no se les opongan, ni desnaturalicen.

(d) Resulta conveniente recurrir a los artículos 36 y 38 de la LJ.

(e) "Cabe mencionar que no se está reconociendo que la Ley No 27153 sea aplicable al caso, sin embargo; debe advertirse que al no haber una definición de ingresos en la mencionada Ley del Impuesto a la Renta, resulta válida la interpretación del término Ingresos conforme a lo señalado por la Ley $N^{\circ} 27153$, como lo indica la demandante.

Como bien puede advertirse, el impuesto a los juegos de casino y máquinas tragamonedas (el cual grava la explotación de estos juegos) establece que no se toma como ingreso neto mensual la totalidad de lo recibido por las apuestas o el dinero destinado al juego, sino que a este monto se le debe deducir lo entregado por los premios otorgados en el mismo mes, es decir, que no se consideran ingresos netos a todo lo que se recibe por las apuestas, tal como señalan la Administración Tributaria y el Tribunal Fiscal.

Por tal motivo, de acuerdo a la interpretación realizada de la Ley $\mathrm{N}^{\mathrm{o}} 27153$, podemos concluir que los "ingresos netos" que se mencionan en el artículo $85^{\circ}$ de la Ley del Impuesto a la Renta, para efectos de aquellos sujetos que explotan máquinas tragamonedas y juegos de casinos, serán aquellos resultantes de la 
diferencia entre el monto total recibido por las apuestas y el monto total entregado por los premios otorgados en el mismo mes."

(f) Adicionalmente a lo detallado en el literal (e) precedente, sostiene que es factible aplicar conceptos que no son de la legislación tributaria que permiten tener claridad sobre la definición de ingresos. A continuación, transcribo lo manifestado en el numeral II.7.4 de la indicada sentencia:

resulta factible la aplicación de conceptos que no se encuentran en la legislación tributaria que puedan ayudarnos a hallar una definición de "ingresos" para el caso concreto; entre esos conceptos, podemos encontrar las Normas Internaciones de Contabilidad, las cuales si bien no deben ser utilizadas, prima facie, como fuentes del derecho tributario, su relación con la normativa tributaria ha sido reconocida en diversas oportunidades por la Administración Tributaria, el Tribunal Fiscal y el Poder judicial, sin que ello haya desnaturalizado las normas tributarias.

En ese sentido, resulta factible la aplicación de la NIC $\mathrm{N}^{\circ} 18$, vigente en el ejercicio que fue materia de fiscalización, la cual define los ingresos en su numeral 7 (...) (p. 13 y 14$)$

Considero que el planteamiento efectuado por el Décimo Noveno Juzgado Contencioso Administrativo en la Especialidad Tributaria Aduanera de la Corte Superior de Justicia de Lima, resulta ser acertado. En efecto, la aplicación de la integración analógica vía la Norma IX del Título Preliminar del CT con la cual se busca cubrir la omisión del concepto de "ingreso" existente en el artículo 85 de la LIR, con el concepto de ingreso existente en los artículos 36 y 38 de la LJ resulta apropiado.

Tal aplicación de integración analógica no implica una violación del artículo 74 de la Constitución, ni de las Normas IV y VIII del Título Preliminar del CT, ya que vía integración analógica no se está creando tributo alguno, ni modificando elementos esenciales de la obligación tributaria; sólo se le está atribuyendo contenido a un concepto de la LIR que se encuentra carente del mismo. 


\section{CONCLUSIONES}

- Cuando me refiero a los pagos a cuenta, no resulta técnico, ni correcto emplear el término "pago" como parte de la denominación atribuida a tal mecanismo de recaudación anticipada, ya que en la oportunidad en que se configura no existe una obligación tributaria principal que deba ser extinguida. Resulta apropiado el empleo de términos como "Anticipos", "Adelantos" o "Ingresos a Cuenta" para referirnos a tales mecanismos de recaudación anticipada.

- Los Anticipos constituyen obligaciones tributarias sustantivas y provisionales, vinculadas a una obligación tributaria principal y definitiva que es el impuesto una vez determinado.

- Siendo el Anticipo una obligación tributaria, le resulta de aplicación el principio constitucional de igualdad, contemplado en el artículo 74 de la Constitución. Ello implica que los Anticipos deben estructurarse en función a elementos presuntos de capacidad económica.

- Si los Anticipos transgreden el principio de igualdad (capacidad económica) se atentará contra la propiedad y deviene en confiscatorio.

- El hecho que, un contribuyente, para cumplir con una obligación tributaria (Anticipo) se vea obligado a afectar significativamente su patrimonio e incluso emplear bienes (fondos) ajenos, implica que tal obligación califica como una confiscatoria.

- Del ejercicio numérico realizado en el capítulo I de la presente investigación, se evidencia que de implementarse la interpretación planteada por SUNAT (respecto de la base de cálculo de los anticipos de tercera categoría del IR), en las fiscalizaciones efectuadas a empresas operadoras de casinos y/o salas de máquinas tragamonedas y ratificada, posteriormente, por el Tribunal Fiscal en las RTFs N ${ }^{\circ}$ 00908-2-2016, 01879-2-2016, 02099-5-2016 y 02100-5-2016; se estaría obligando a efectuar anticipos de la tercera categoría del IR que excederían ampliamente el IR que corresponde por el ejercicio. En el caso planteado, implicaba efectuar anticipos equivalentes al pago del IR de los próximos dieciocho (18) años en un escenario pesimista y el IR de los próximos diez (10) años en un escenario optimista. 
- En el ejemplo numérico planteado en el capítulo I del presente trabajo, se evidencia un efecto confiscatorio respecto de los anticipos de la tercera categoría del IR; en caso se determinen bajo la interpretación planteada por SUNAT. En efecto, el hecho de anticipar un monto equivalente al IR de los próximos diez (10) años implica afectar la propiedad de los operadores de casino y salas de máquinas tragamonedas.

- La interpretación inicialmente planteada por SUNAT y con la cual continúa el TF, genera una transgresión a los principios constitucionales de igualdad, de no confiscatoriedad y del principio constitucional implícito de capacidad contributiva.

- Bajo el entendido que las normas contables (MC, NIC y NIIF) no constituyen normas jurídicas, no pueden ser empleadas supletoriamente al amparo de la Norma IX del Título Preliminar del CT. Ello debido a que: (a) La analogía es admitida, restrictivamente, para cubrir vacíos en normas tributarias, empleando para ello otra norma jurídica (dentro de las que no están comprendidas las normas contables) o los principios del derecho administrativo o principios generales del derecho, (b)La analogía en el derecho tributario se encuentra limitado a aspectos distintos de los elementos esenciales del tributo. De aplicarse la integración analógica para cubrir vacíos en los aspectos esenciales del tributo, se configuraría una violación de la reserva de ley contemplada en el artículo 74 de la Constitución Política de 1993, (c) En el hipotético y negado caso que las normas contables calificarán como normas jurídicas y que se permitiera la aplicación de la integración analógica para los elementos esenciales del tributo; aún así no podría emplearse la Norma IX del Título Preliminar del CT. Ello debido a que, de calificar las normas contables como una norma jurídica; el rango de las mismas sería equivalente a las resoluciones del Consejo Normativo de Contabilidad y su aplicación violaría la reserva de ley del artículo 74 de la Constitución Política de 1993.

- En todos aquellos pronunciamientos efectuados por SUNAT y el TF en las que han empleado la Norma IX del Título Preliminar del CT, para incorporar disposiciones contables (como es el concepto de ingreso) a disposiciones tributarias, incurren en un error y en una violación expresa del artículo 74 de la Constitución Política de 1993.

- La Norma IX del Título Preliminar del CT debió ser empleada por SUNAT y el TF en sus pronunciamientos, para cubrir el vacío existente en el artículo 85 de la LIR y 
el artículo 54 del RLIR, respecto de la definición de "ingreso"; siendo objeto de integración analógica los conceptos existentes en los artículos 10, 36 y 38 de la LJ; de los que se desprende el concepto de ingreso en la actividad de casinos y salas de máquinas tragamonedas.

- Las normas contables (MC y NIC 18) pueden ser asimiladas como doctrina e incorporadas como fuente del derecho tributario, de acuerdo a la Norma III del Título Preliminar del CT. En ese caso, tales normas contables (MC y NIC 18) pueden colaborar para obtener una definición/satisfactoria de lo que es ingreso para los anticipos de tercera categoría del IR.

- Las apuestas que reciben las empresas operadoras de casinos y salas de máquinas tragamonedas, no califican como ingresos. Ello debido a que al existir una obligación legal del retorno mínimo del $85 \%$, tales fondos no son de libre disposición de la empresa operadora, es decir, tales fondos no son de su propiedad; no pudiendo generarse un incremento en el activo de tal empresa.

- El ingreso en las empresas operadoras de casino y/o salas de máquinas tragamonedas, se encuentra constituido por el diferencial (Net Win) derivado de restar a las apuestas efectuadas por el público (Coin In), los premios pagados en el mismo período (Coin Out).

- Los Anticipos del IR deben ser determinados tomando como base el Net Win detallado en la conclusión precedente.

- El criterio planteado por SUNAT en los Informes No 188-2015-SUNAT/5D0000 y 002-2017-SUNAT/5D0000, rectifican el criterio planteado por esa misma institución durante los procesos de fiscalización y que dieron origen a diversos procesos administrativos tributarios.

- Sin perjuicio de lo detallado en la conclusión precedente, el análisis efectuado por SUNAT en los Informes $\mathrm{N}^{\mathrm{o}}$ 188-2015-SUNAT/5D0000 y 002-2017SUNAT/5D0000, resulta ser deficiente. Ello debido a que efectúan una integración analógica de las normas contables (MC y NIC 18) para cubrir la omisión en la definición del concepto de "ingreso" del artículo 85 de la LIR, lo que efectúan al amparo de la Norma IX del Título Preliminar del CT. Sin embargo, ello no resulta posible ya que la integración analógica sólo puede efectuarse respecto de normas jurídicas y el MC y la NIC 18 no califican como tales. En esos casos SUNAT debió 
emplear la Norma IX del Título Preliminar del CT, respecto de los artículos 10, 36 y 38 de la LJ y la Norma III del Título Preliminar del CT para emplear el MC y la NIC 18 como doctrina.

- Existe abierta discrepancia entre lo sostenido por SUNAT en los Informes № 188 2015-SUNAT/5D0000 y 002-2017-SUNAT/5D0000 y lo manifestado por las Salas 2 y 5 del TF en las RTFs No 00908-2-2016, 02099-5-2016 y 02100-5-2016.

- La sentencia dictada en el expediente $\mathrm{N}^{\circ}$ 05325-2016-0-1801-JR-CA-19 por el Décimo Noveno Juzgado Contencioso Administrativo en la Especialidad Tributaria Aduanera de la Corte Superior de Justicia de Lima, de forma acertada cubre la omisión (laguna de ley) existente en el artículo 85 de la LIR, respecto de la definición de "ingreso", al efectuar una integración analógica del concepto de ingreso existente en el artículo 38 de la LJ.

- La integración analógica efectuada en la sentencia del expediente $\mathrm{N}^{\circ}$ 05325-2016-01801-JR-CA-19 por el Décimo Noveno Juzgado Contencioso Administrativo, no constituye una violación del artículo 74 de la Constitución, ni de las Normas IV y VIII del Título Preliminar del CT, ya que vía tal integración analógica no se está creando tributo alguno, ni modificando elementos esenciales de la obligación tributaria; sólo se le está otorgando contenido a un concepto de la LIR que se encuentra carente del mismo.

- Es necesario incorporar en la LIR el concepto de "ingreso"; con la finalidad de eliminar la laguna de ley existente actualmente. Para ello, puede incorporarse un texto que en su concepto sea similar a las disposiciones del MC y la NIC 18.

- Lo detallado en la conclusión precedente se habría logrado hace mucho tiempo atrás, si la Administración Tributaria hubiera ejercido la facultad conferida en el artículo 95 del CT, no sólo para el caso del concepto de "ingreso"; sino también para definiciones tales como la del "devengado". 


\section{REFERENCIAS}

Alzamora Valdez, M. (1984). Introducción a la Ciencia del Derecho, Novena Edición. Lima: Tipografía Sesator.

Borda, G. A. (1983). Tratado de Derecho Civil, Contratos II, Quinta Edición. Buenos Aires: Editorial Perrot.

Bravo Arteaga, J. R. (2012). Nociones Fundamentales de Derecho Tributario. Bogotá: Legis.

Bravo Cucci, J. (2013). Derecho Tributario Reflexiones. Lima: Juristas Editores.

Bravo Cucci, J. (2014). La contabilidad como fuente de derecho, II Foro Internacional de Tributación y Contabilidad, Tomo II, Instituto Peruano de Investigación y Desarrollo Tributario. Lima: Thomson Reuters.

Danos Ordoñez, J. (2006). El principio constitucional de no confiscatoriedad de los tributos en la jurisprudencia del Tribunal Constitucional Peruano. En: Libro Homenaje a Armando Zolezzi Moller. Lima: Palestra.

De Juano, M. (1969). Curso de Finanzas y Derecho Tributario, Tomo I, Segunda Edición. Rosario: Ediciones Molachino.

De La Puente y Lavalle, M. (1991). El Contrato en General, Comentarios a la Sección Primera del Libro VII del Código Civil, Primera Parte - Tomo I. Lima: Fondo Editorial de la Pontificia Universidad Católica del Perú.

Duran Rojo, L. y Mejía Acosta, M. (2011). Las NIIF y la interpretación de las normas tributarias por SUNAT. Lima: Análisis Tributario.

Fernández Cartagena, J. A. (1989). Otra aproximación jurídica al tema del reajuste tributario y los pagos a cuenta. Cuadernos Tributarios $\mathrm{N}^{\circ}$ 07. Lima: Asociación Fiscal Internacional (IFA) Grupo Peruano.

Ferreiro Lapatza, J. J. (2010). Instituciones de Derecho Financiero. Madrid: Marcial Pons.

Gamba Valega, C. M. (2014). Reserva de Ley y Normas Contables. Breves Apuntes para una Polémica, I Foro Internacional de Tributación y Contabilidad, Tomo I, Instituto Peruano de Investigación y Desarrollo Tributario, Lima: Thomson Reuters.

García Belsunce, H. A. (1982). Temas de Derecho Tributario. Buenos Aires: AbeledoPerrot.

García Berro, F. (2013). Curso de Derecho Tributario Parte Especial. Séptima Edición. Madrid: Editorial Tecnos. 
García Mullin, R. (1978). Impuesto a la Renta: Teoría y Técnica del Impuesto. Centro Interamericano de Estudios Tributarios (CIET), Organización de Estados Americanos, Buenos Aires.

Gil Cruz, E. (2010). Capítulo 27 Pagos a cuenta en el Impuesto sobre Sociedades del libro El Impuesto sobre Sociedades, Segunda Edición Ampliada y Revisada. Pamplona: Thompson Reuters.

Giuliani Fonrouge, C. (1993): Derecho Financiero, Vol. I, 5ta. Edición. Buenos Aires: Depalma.

Jarach, D. (1983). Finanzas Públicas y Derecho Tributario, 2da. Edición. Buenos Aires: Abeledo-Perrot.

Landa Arroyo, C. (2006). Los principios tributarios en la Constitución de 1993: Una perspectiva constitucional. En: Libro Homenaje a Armando Zolezzi Moller. Lima: Palestra.

Lara Márquez, J. (1997). La analogía en el Derecho Tributario: Revista del Instituto Peruano de Derecho Tributario, No 32, IPDT. Lima.

Lázaro Orihuela, A. E. (2016). La naturaleza de los pagos a cuenta: de empréstitos forzosos a obligaciones tributarias. En: Actualidad Jurídica $\mathrm{N}^{\circ} 277$. Lima: Gaceta Jurídica S.A.

León Huayanca, M. (2014); Uso de las NIIF como Fuente Normativa e Interpretación en el Impuesto a la Renta, "I Foro Internacional de Tributación y Contabilidad", Tomo I, Instituto Peruano de Investigación y Desarrollo Tributario. Lima: Thomson Reuters.

López Maza, S. (2011). El Contrato de Juego y Apuesta en el Ámbito Civil. Pamplona: Editorial Aranzadi S.A.

Luque Bustamante, J. (1988). Reflexiones sobre la naturaleza jurídica de los pagos a cuenta en el Impuesto a la Renta. Análisis Tributario, Vol. I, Nº 9.

Luque Bustamante, J. (1989). El Reajuste del Tributo en los Pagos a Cuenta: Revista del Instituto Peruano de Derecho Tributario, N 16, IPDT. Lima.

Luque Bustamante, J. y Padrón Freundt, C. (1989). Efectos del reajusten los pagos a cuenta, En Cuadernos Tributarios № 7. Lima: Asociación Fiscal Internacional (IFA) Grupo Peruano.

Luyo Acosta, K. (2014). La interacción entre el resultado contable y la base imponible, II Foro Internacional de Tributación y Contabilidad, Tomo II, Instituto Peruano de Investigación y Desarrollo Tributario. Lima: Thomson Reuters.

Mares Ruiz, C. (2008). La Retención a Cuenta en el IRPF. (Tesis para optar el título de Doctor) Universidad de Navarra, España.

Mur Valdivia, M. (2002); Relator General Tema 1 El Criterio de lo Devengado en el Impuesto a la Renta, VII Jornadas Nacionales de Tributación IFA-Perú, 
Cuadernos Tributarios N ${ }^{\circ}$ 27. Lima: Asociación Fiscal Internacional (IFA) Grupo Peruano.

Navarro Faure, A. (2007); El Derecho Tributario ante el Nuevo Derecho Contable,

Madrid: La Ley Grupo Wolters Kluwer.

Rojina Villegas, R. (1979) Compendio de Derecho Civil, Tomo IV - Contratos, México D.F.: Editorial Porrúa S.A.

Rubio Correa, M. (2011). El Sistema Jurídico: Introducción al Derecho, 10ma. Edición. Lima: Fondo Editorial - PUCP.

Santos Briz, J. (1973). Derecho Civil Teoría y Práctica, Tomo IV. Madrid: Editorial Revista de Derecho Privado.

Sevillano Chávez, S. (2016) Lecciones de Derecho Tributario, Principios Generales y Código Tributario, Lima: Fondo Editorial de la Pontificia Universidad Católica del Perú.

Smith, J. C. (1990). Enciclopedia Jurídica Omeba, Tomo XX, Buenos Aires: Driskill S.A.

Sotelo Castañeda, E. y Vargas León, L. (1998) En torno a la definición de tributo: Un vistazo a sus elementos esenciales. En: Ius et Veritas $\mathrm{N}^{\circ} 17$.

Villanueva Gonzales, M. (2004) Las Rentas Empresariales, Ponencia Individual contenida en la recopilación de las Séptimas Jornadas Nacionales de Derecho Tributario, organizadas por el Instituto Peruano de derecho Tributario - IPDT, realizadas entre el 13 al 15 de septiembre de 2004.

Villanueva Gutiérrez, W. (2003). Aplicación de los principios constitucionales al anticipo adicional del impuesto a la renta. Análisis Tributario, volumen XVI N ${ }^{\circ}$ 184. Lima: Asesoramiento y Análisis Laborales S.A.C. - AELE.

Villegas, H. B. (1987) Curso de Finanzas, Derecho Financiero y Tributario, Cuarta Edición actualizada. Buenos Aires: Ediciones Depalma.

Villegas, H. B. (1988) Curso de Finanzas, Derecho Financiero y Tributario, Buenos Aires: Depalma. 


\section{BIBLIOGRAFÍA}

AICPA (2014). Gaming, Audit \& Accounting Guide. NY, USA.

Alguacil Mari, M. P. (1995). La retención a cuenta en el ordenamiento tributario español. Pamplona: Aranzadi.

Alzamora Valdez, M. (1984). Introducción a la Ciencia del Derecho, Novena Edición. Lima: Tipografía Sesator.

Ambrosini, C. E. (1979). Contrato de Juego, Enciclopedia Jurídica Omeba Tomo IV. Buenos Aires: Driskill S.A.

Borda, G. A. (1983). Tratado de Derecho Civil, Contratos II, Quinta Edición. Buenos Aires: Editorial Perrot.

Bravo Arteaga, J. R. (2012). Nociones Fundamentales de Derecho Tributario. Bogotá: Legis.

Bravo Cucci, J. (2013). Derecho Tributario Reflexiones. Lima: Juristas Editores.

Bravo Cucci, J. (2014). La contabilidad como fuente de derecho, II Foro Internacional de Tributación y Contabilidad, Tomo II, Instituto Peruano de Investigación y Desarrollo Tributario. Lima: Thomson Reuters.

Danos Ordoñez, J. (2006). El principio constitucional de no confiscatoriedad de los tributos en la jurisprudencia del Tribunal Constitucional Peruano. En: Libro Homenaje a Armando Zolezzi Moller. Lima: Palestra.

De Juano, M. (1969). Curso de Finanzas y Derecho Tributario, Tomo I, Segunda Edición. Rosario: Ediciones Molachino.

De La Puente y Lavalle, M. (1991). El Contrato en General, Comentarios a la Sección Primera del Libro VII del Código Civil, Primera Parte - Tomo I. Lima: Fondo Editorial de la Pontificia Universidad Católica del Perú.

Díaz Gómez, M. J. (2004). El Contrato Aleatorio, Universidad de Huelva. Granada: Editorial Comares. 
Duran Rojo, L. y Mejía Acosta, M. (2011). Las NIIF y la interpretación de las normas tributarias por SUNAT. Lima: Análisis Tributario.

Eadington \& Cornelius (1991); Gambling and Public Policy, International

Perspectives, Institute for the Study of Gambling and Commercial Gaming, University of Nevada.

Estrada Espinoza, M. E. y García Vélez, J. H. (2013). ¿Es necesario regular? Análisis del Marco Legal de los Juegos de Azar y Apuestas en el Perú, Revista IUS ET VERITAS, $\mathrm{N}^{\circ} 46$.

Fernández Cartagena, J. A. (1989). Otra aproximación jurídica al tema del reajuste tributario y los pagos a cuenta. Cuadernos Tributarios № 07. Lima: Asociación Fiscal Internacional (IFA) - Grupo Peruano.

Ferreiro Lapatza, J. J. (2010). Instituciones de Derecho Financiero. Madrid: Marcial Pons.

Gamba Valega, C. M. (2014). Reserva de Ley y Normas Contables. Breves Apuntes para una Polémica, I Foro Internacional de Tributación y Contabilidad, Tomo I, Instituto Peruano de Investigación y Desarrollo Tributario, Lima: Thomson Reuters.

García Belsunce, H. A. (1982). Temas de Derecho Tributario. Buenos Aires: AbeledoPerrot.

García Berro, F. (2013). Curso de Derecho Tributario Parte Especial. Séptima Edición. Madrid: Editorial Tecnos.

García Mullin, R. (1978). Impuesto a la Renta: Teoría y Técnica del Impuesto. Centro Interamericano de Estudios Tributarios (CIET), Organización de Estados Americanos, Buenos Aires.

García Vizcaíno, C. (2000). Derecho Tributario, Tomo II. Buenos Aires: Ediciones Depalma.

Ghersi, C. A. (1990). Contratos Civiles y Comerciales, Partes General y Especial Figuras Contractuales Modernas. Buenos Aires: Astrea.

Gil Cruz, E. (2010). Capítulo 27 Pagos a cuenta en el Impuesto sobre Sociedades del libro El Impuesto sobre Sociedades, Segunda Edición Ampliada y Revisada. Pamplona: Thompson Reuters. 
Giuliani Fonrouge, C. (1993): Derecho Financiero, Vol. I, 5ta. Edición. Buenos Aires: Depalma.

Greenlees M. (2008) Casino Accounting and Financial Managment, Second Edition, University of Nevada.

Jarach, D. (1983). Finanzas Públicas y Derecho Tributario, 2da. Edición. Buenos Aires: Abeledo-Perrot.

Landa Arroyo, C. (2006). Los principios tributarios en la Constitución de 1993: Una perspectiva constitucional. En: Libro Homenaje a Armando Zolezzi Moller. Lima: Palestra.

Lara Márquez, J. (1997). La analogía en el Derecho Tributario: Revista del Instituto Peruano de Derecho Tributario, No 32, IPDT. Lima.

Lázaro Orihuela, A. E. (2016). La naturaleza de los pagos a cuenta: de empréstitos forzosos a obligaciones tributarias. En: Actualidad Jurídica No 277. Lima: Gaceta Jurídica S.A.

León Barandiarán, J. (1975). Contratos en el Derecho Civil Peruano, Tomo II. Lima. León Huayanca, M. (2014); Uso de las NIIF como Fuente Normativa e Interpretación en el Impuesto a la Renta, "I Foro Internacional de Tributación y Contabilidad", Tomo I, Instituto Peruano de Investigación y Desarrollo Tributario. Lima: Thomson Reuters.

López Maza, S. (2011). El Contrato de Juego y Apuesta en el Ámbito Civil. Pamplona: Editorial Aranzadi S.A.

Luque Bustamante, J. (1988). Reflexiones sobre la naturaleza jurídica de los pagos a cuenta en el Impuesto a la Renta. Análisis Tributario, Vol. I, N 9.

Luque Bustamante, J. (1989). El Reajuste del Tributo en los Pagos a Cuenta, Revista del Instituto Peruano de Derecho Tributario, No 16, IPDT. Lima.

Luque Bustamante, J. y Padrón Freundt, C. (1989). Efectos del reajusten los pagos a cuenta, En Cuadernos Tributarios N $\mathrm{N}^{\mathrm{T}}$ 7. Lima: Asociación Fiscal Internacional (IFA) Grupo Peruano. 
Luyo Acosta, K. (2014). La interacción entre el resultado contable y la base imponible, II Foro Internacional de Tributación y Contabilidad, Tomo II, Instituto Peruano de Investigación y Desarrollo Tributario. Lima: Thomson Reuters.

Mares Ruiz, C. (2008). La Retención a Cuenta en el IRPF. (Tesis para optar el título de Doctor) Universidad de Navarra, España.

Marzon Hernández, M. (2007). Análisis Económico Jurídico y Fiscal del Juego. Valencia: Tirant monografías.

Mata Sierra, M. T. (2009). El Principio de Igualdad Tributaria. Navarra: Aranzadi Thomson Reuters.

Mur Valdivia, M. (2002); Relator General Tema 1 El Criterio de lo Devengado en el Impuesto a la Renta, VII Jornadas Nacionales de Tributación IFA-Perú, Cuadernos Tributarios No 27. Asociación Fiscal Internacional (IFA) Grupo Peruano.

Navarro Faure, A. (2007); El Derecho Tributario ante el Nuevo Derecho Contable, Madrid: La Ley Grupo Wolters Kluwer.

Palomar Olmeda, A. (director) (2013). En Torno al juego de Azar, Actividad, Regulación y Actores. España: Thomson Reuters Aranzadi.

Queralt, J. M., Lozano Serrano, C., Poveda Blanco, F. (2008) Derecho Tributario. Navarra: Editorial Aranzadi S.A.

Rodríguez Ondarza, J. A. (director) (2010). El Impuesto sobre Sociedades, segunda edición. Pamplona: Editorial Aranzadi.

Rojina Villegas, R. (1979) Compendio de Derecho Civil, Tomo IV - Contratos, México D.F.: Editorial Porrúa S.A.

Rubio Correa, M. (2011). El Sistema Jurídico: Introducción al Derecho, 10ma. Edición. Lima: Fondo Editorial - PUCP

Saccone, M. A. (2002). Manual de Derecho Tributario. Buenos Aires: La Ley S.A.

Santos Briz, J. (1973). Derecho Civil Teoría y Práctica, Tomo IV. Madrid: Editorial Revista de Derecho Privado. 
Sevillano Chávez, S. (2016) Lecciones de Derecho Tributario, Principios Generales y Código Tributario, Lima: Fondo Editorial de la Pontificia Universidad Católica del Perú.

Siota Alvarez, M. (2010) Analogía e interpretación en el derecho tributario. Madrid: Marcial Pons.

Smith, J. C. (1990). Enciclopedia Jurídica Omeba, Tomo XX, Buenos Aires: Driskill S.A.

Sotelo Castañeda, E. y Vargas León, L. (1998) En torno a la definición de tributo: Un vistazo a sus elementos esenciales. En: Ius et Veritas $\mathrm{N}^{\circ} 17$.

Suarez Diaz, G. (1998) Aspectos Prácticos a considerarse en la determinación de los pagos a cuenta del Impuesto a la Renta de Tercera Categoría, Vol. 34, de la Revista del Instituto Peruano de Derecho Tributario.

Villanueva Gonzales, M. (2004) Las Rentas Empresariales, Ponencia Individual contenida en la recopilación de las Séptimas Jornadas Nacionales de Derecho Tributario, organizadas por el Instituto Peruano de derecho Tributario - IPDT, realizadas entre el 13 al 15 de septiembre de 2004.

Villanueva Gutiérrez, W. (2003). Aplicación de los principios constitucionales al anticipo adicional del impuesto a la renta. Análisis Tributario, volumen XVI N ${ }^{\circ}$ 184. Lima: Asesoramiento y Análisis Laborales S.A.C. - AELE.

Villegas, H. B. (1987) Curso de Finanzas, Derecho Financiero y Tributario, Cuarta Edición actualizada. Buenos Aires: Ediciones Depalma.

Villegas, H. B. (1988) Curso de Finanzas, Derecho Financiero y Tributario, Buenos Aires: Depalma.

Willhelm Kruse, H. (1978). Derecho Tributario. Madrid: Editoriales de Derecho Reunidas S.A. 